Economía y Derecho penal en Europa:

una comparación entre las experiencias italiana y española Actas del Congreso hispano-italiano de Derecho penal económico Università degli Studi di Milano, Milano, 29-30 de mayo de 2014

cursos_congresos_simposios 


\section{Economía y Derecho penal en Europa:}

una comparación entre las experiencias italiana y española

Actas del Congreso hispano-italiano de Derecho penal económico (Università degli Studi di Milano, Milano, 29-30 de mayo de 2014)

Edición a cargo de Luz María Puente Aba

A Coruña 2015

Universidade da Coruña

Servizo de Publicacións 
Economía y Derecho penal en Europa: una comparación entre las experiencias italiana y española. Actas del Congreso hispano-italiano de Derecho penal económico (Università degli Studi di Milano, Milano, 29-30 de mayo de 2014)

Puente Aba, Luz María (editora)

A Coruña, 2015

Universidade da Coruña, Servizo de Publicacións

Cursos_congresos_simposios, n. ${ }^{\circ} 140$

N. ${ }^{\circ}$ de páxinas: 318

$17 \times 24 \mathrm{~cm}$

Índice: páx. 5-6

ISBN: 978-84-9749-632-2 (impreso)

Depósito legal: C 2313-2015

ISBN: 978-84-9749-732-9 (electrónico)

CDU: $343(460+450)(063)$

IBIC: LNF | 1DSE | 1DST

EDICIÓN

Universidade da Coruña, Servizo de Publicacións (http://www.udc.gal/publicacions)

(C) Universidade da Coruña

(C) Os autores

Esta obra foi revisada e avaliada por dous expertos non pertencentes á UDC

DISTRIBUCIÓN

Galicia:

- Consorcio Editorial Galego. Av. da Estación 25, 36812 Redondela (Pontevedra) pedimentos@coegal.com

España e internacional:

- Logística Libromares, S.L. C/ Matilde Hernández 34, 28019 Madrid (España) pedidos@libromares.com

- Pórtico Librerías. C/ Muñoz Seca 6, 50005 Zaragoza (España) distribucion@porticolibrerias.es

Deseño da cuberta: Julia Núñez Calo

IMPRIME

Lugami Artes Gráficas

Reservados todos os dereitos. Nin a totalidade nin parte deste libro pode reproducirse ou transmitirse por ningún procedemento electrónico ou mecánico, incluíndo fotocopia, gravación magnética ou calquera almacenamento de información e sistema de recuperación, sen o permiso previo e por escrito das persoas titulares do copyright. 


\section{Índice}

Eva María Souto García

Presentación

Congreso hispano-italiano de Derecho penal económico: Economía y Derecho penal en Europa. Una comparación entre las experiencias española e italiana

María Acale Sánchez

La lucha contra la corrupción en el ámbito supranacional y su incidencia en el Código penal español

Javier Gustavo Fernández Teruelo

El fenómeno de la corrupción en España: respuesta penal y propuestas de reforma

Francesco Viganò

I delitti di corruzione nell'ordinamento italiano: qualche considerazione sulle reforme già fatte, e su quel che resta da fare

Luz María Puente Aba

Tutela penal del inversor / consumidor e ilícitos penales en la empresa.....

Juan Carlos Hortal Ibarra

Crisis financiera, delincuencia de cuello blanco y respuesta penal: una aproximación criminológica y político-criminal

Luigi Foffani

Politica criminale europea e sistema finanziario: l'esempio degli abusi di mercato

Sergio Seminara

Riserve extrabilancio e gestione d'impresa: profili penali

Patricia Faraldo Cabana

Acerca de la idoneidad de la sanción pecuniaria para personas jurídicas. Una reflexión de Derecho español con apuntes de Derecho italiano 
Norberto J. de la Mata Barranco

Los protocolos de prevención de delitos en el ámbito empresarial: el referente de los modelos de organización y gestión de la regulación italiana ...

Antonio Fiorella / Nicola Selvaggi

'Compliance programs' e dominabilità 'aggregata' del fatto. Verso una responsabilità da reato dell'ente compiutamente personale 


\title{
Crisis financiera, delincuencia de cuello blanco y respuesta penal: una aproximación criminológica y político-criminal*
}

\author{
JuAn CARlos Hortal IBARRA \\ Profesor Agregado de Derecho penal Universidad de Barcelona**
}

"Las leyes civiles son como las telarañas,
cazan moscas y dejan que los elementos
volantes mayores las atraviesan"
Juan de Salisbury, año 1166

* El presente artículo coincide sólo en parte con la ponencia que bajo el título "Una aproximación políticocriminal a la protección penal del inversor minorista" presenté en mayo de 2014 en el seminario HispanoItaliano celebrado en la Università degli Studi di Milano. Sirva esta tribuna para agradecer, en esta ocasión por escrito, la amable invitación cursada por la Prof. Luz María Puente Aba y la hospitalidad brindada, por el también co-organizador del encuentro, el Prof. Francesco Viganò. Un agradecimiento que hago extensivo a los Profs. Santiago Mir, Mirentxu Corcoy y Vicente Valiente por el tiempo dedicado a su lectura y las atinadas observaciones que, sin duda, han contribuido a mejorarlo. Este trabajo se enmarca en el Proyecto de Investigación DER2011-29982 concedido por el Ministerio de Ciencia e Innovación y capitaneado por el Prof. Víctor Gómez Martín.

** Índice de abreviaturas: ADPCP (Anuario de Derecho Penal y Ciencias Penales); AP (Actualidad Penal); ASR (American Socialogical Review); DLL (Diario La Ley); DPyCr (Derecho Penal y Criminología, Universidad Externado de Colombia); CPC (Cuadernos de Política Criminal); GEPC (Grupo de Estudios de Política Criminal); LH (Libro Homenaje); LL (Revista La Ley); LLP (La Ley Penal); LMV (Ley del Mercado de Valores); PC (Política Criminal: Revista Electrónica Semestral de Políticas Públicas en Materias Penales, Universidad de Talca, Chile); RAD (Revista Aranzadi Doctrinal); RDBB (Revista de Derecho Bancario y Bursátil); RDF (Revista de Derechos Fundamentales, Universidad Viña del Mar, Chile); RDL (Real Decreto Legislativo); RDMV (Revista de Derecho del Mercado de Valores); RDPC (Revista de Derecho Penal y Criminología); RDyPP (Revista de Derecho y Proceso Penal); REIC (Revista Española de Investigación Criminológica); RGDP (Revista General de Derecho Penal); RP (Revista Penal); RPJ (Revista del Poder Judicial). 
SumArio: 1. Planteamiento. - 2. Crisis, (des)regulación del sistema financiero y tutela -penaldel inversor minorista: al rescate del "Derecho penal bancario". - 3. Prevención y castigo de las-cíclicas-crisis económicas y sus efectos: de actitudes y eficacias en la persecución y enjuiciamiento de los delitos socioeconómicos. -4 . Vademécum punitivo contra la criminalidad de cuello blanco: a) Aproximación criminológica a los rasgos de la delincuencia socioeconómica; b) La empresa como factor criminógeno: ¿Es la RPPJ la mejor respuesta para combatir esta realidad?; c) Su incidencia en el-racional-diseño político-criminal del sistema de penas: multa, inhabilitación profesional y prisión.

\section{Planteamiento}

1. Tomando como telón de fondo los riesgos jurídico-penales derivados de la intermediación financiera ${ }^{1}$, me ocupo en esta incursión en el sobreexplotado pero revitalizado Derecho penal económico ${ }^{2}-$ o mejor dicho, de empresa ${ }^{3}$-, de diversas y controvertidas

\footnotetext{
${ }^{1}$ Estoy pensando, fundamentalmente, en dos grupos de casos. Aquéllos en que el intermediario coloca activos financieros de cuya elevada toxicidad tiene cumplido conocimiento. Y aquéllos otros en que, infringiendo elementales deberes de diligencia, no comprueba la real y efectiva peligrosidad del producto que acaba endosando igualmente a su clientela. En ambos supuestos, nuestro intermediario obtiene una suculenta comisión por cada una de las operaciones ejecutadas, al tiempo que lesiona el patrimonio individual de su cliente. Y, lo que resulta si cabe todavía más grave, de generalizarse el comportamiento entre una pluralidad de víctimas -lo cual, por otra parte, es lo habitual-, menoscaba adicionalmente la confianza del ahorrador-inversor en el cabal funcionamiento del mercado financiero en tanto pilar del sistema capitalista. ${ }^{2}$ Como muy atinadamente ha puesto de relieve ORTIZ DE URBINA GIMENO, "El derecho penal económico desde el análisis económico del Derecho penal: ¿Es posible la disuasión?, en Crisis financiera y Derecho Penal Económico, DEMETRIO CRESPO / MAROTO CALATAYUD (coords.), Eds. Edisofer/ Bdef, Madrid-Montevideo, 2014, pp. 113-114, la vitalidad de la que actualmente goza el penal económico trae causa del elevado número de escándalos económicos en que se exigen, con más o menos fortuna, responsabilidades de esta naturaleza. Lo cual, a su vez, podría explicar el plus de atención dispensado por la doctrina que habría encontrado en este ámbito un mayor rédito al logrado en otros sectores -añadiría yo-más vinculados al clásico "Derecho penal nuclear" (vida, integridad física, libertad-sexual-, propiedad y salud pública -tráfico de drogas-). Una recompensa que no se circunscribiría al plano puramente teórico, sino que -en un gesto de sinceridad que le honra- estaría, a juicio del autor, en el origen del creciente interés mostrado por los despachos en la captación de los penalistas académicos como capital humano. Un colectivo que, como también indica ORTIZ DE URBNIA GIMENO, ha visto menguada su capacidad adquisitiva a raíz de los recortes sufridos en la universidad pública y que está sumido en un estado de "cierto sentimiento de abatimiento" (nota 2).

${ }^{3}$ Me decanto por la asunción del término "Derecho penal de la empresa" o "Derecho penal empresarial" al más popularizado "Derecho penal económico" para enfatizar el protagonismo adquirido por estas organizaciones en tanto generadoras de relevantes riesgos penales ad intram y ad extram idóneos para lesionar -no sólo, pero fundamentalmente- bienes jurídicos de naturaleza supraindividual. Es la empresa como principal y actual unidad de producción económica la que dotaría de autonomía a esta parte del Derecho penal y explicaría las dificultades en la detección, persecución y enjuiciamiento de los delitos que se cometen en nombre o sirviéndose de ella. La asunción de este concepto de corte fenomenológico-criminológico y no
} 
cuestiones en torno a la respuesta que, desde una vertiente criminológica y políticocriminal, merece la llamada delincuencia de cuello blanco (white collar criminality) ${ }^{4}$. Esto es, a propósito de la crisis económica y la inestimable participación de los intermediarios financieros en su gestación y desarrollo ${ }^{5}$, ofrezco alguna solución -más o

únicamente jurídico (en atención al bien jurídico-penal protegido -orden socioeconómico-) permitiría abarcar los clásicos delitos económicos (estafa, apropiación indebida, insolvencias punibles, delitos societarios, blanqueo de capitales, etc.). Pero también aquellos comportamientos delictivos de quienes, movidos por el lucro o el enriquecimiento, lesionan bienes jurídicos dentro y fuera de la empresa en tanto organización económico-jurídica compleja. Estoy pensando en los directivos o administradores de la sociedad X que con la finalidad de ahorrarse costes y ser más competitivos en el mercado no implementan ninguna medida de seguridad e higiene en el trabajo y ponen así en grave peligro la vida e integridad física de sus operarios. O no reciclan y/o depuran debidamente los residuos producidos en la empresa y los vierten descontroladamente en el río menoscabando el equilibrio del ecosistema fluvial. O con idéntica intención, elaboran productos alimenticios con materias primas de dudosa calidad y procedencia, prescindiendo de todo control de calidad necesario para preservar la salud de los consumidores. De ahí que me adhiera, en lo fundamental, al planteamiento defendido por FERNÁNDEZ TERUELO, Instituciones de derecho penal económico y de la empresa, Ed. Lex Nova, Valladolid, 2013, pp. 21-27, quien ha puesto de relieve como "el uso y abuso del instrumento societario (la empresa) y de sus múltiples mecanismos en la ejecución de la actividad delictiva es hoy el elemento esencial desde el punto de vista criminológico pero, sobre todo, jurídico; es en definitiva lo que le dota de verdadera autonomía y por ello lo que justifica un tratamiento autónomo". Como apunta el citado autor, el concepto aquí defendido estaría en sintonía con los barajados doctrinalmente en países de nuestro entorno. Tal es el caso de Italia donde, progresivamente, ha ido ganando terreno la expresión "Diritto penale dell'impresa" en detrimento de la más clásica "Diritto penale dell'economia". O Francia, donde también se consolidó hace ya bastante tiempo la categoría del "Droit pénal des affaires" para referirse al conjunto de infracciones penales cometidas en el seno de la empresa y en que sus autores se valen de la misma (p. 25).

${ }^{4}$ Utilizo dicha expresión, digamos en términos coloquiales, como sinónimo de delincuencia económica/ socioeconómica. No lo hago, por tanto, en el sentido original que su progenitor EdwiN SuTHERLAND le confirió en su conferencia pronunciada en 1939 ante la Sociedad Americana de Sociología y posteriormente publicada en la American Sociogical Review bajo el título "White Collar Criminality". Trabajo que, debidamente desarrollado y ampliado, daría lugar al afamado y citadísimo libro White Collar Crime (1949). Al respecto, Vid., las matizaciones realizadas por FERNÁNDEZ TERUELO, Instituciones..., pp. 23-24; y MIRÓ LLINARES, El cibercrimen. Fenomenología y criminología de la delincuencia en el ciberespacio, Ed. Marcial Pons, Madrid, 2012, p. 245 (en especial, la nota 73), para quien se trata de una "categoría de extrema ambigüedad, y en todo caso reconocida como excesivamente amplia por la criminología moderna". No le falta razón a ORTIZ DE URBINA GIMENO, "Too much of a good thing? Marcus Felson, la teoría de las actividades cotidianas y la delincuencia de cuello blanco", en LH-Marcus Felson (MIRÓ / AGUSTINA / MEDINA / SUMMERS (eds.), Ed. Dykinson, Madrid, 2015, p. 501, cuando, siguiendo en este punto al profesor STUART P. GREEN, señala que, posiblemente, estemos ante el concepto criminológico más popular. Así lo corroboraría el hecho de que haya traspasado las rígidas barreras de lo académico para instalarse en el "imaginario cultural colectivo" donde se identifica, fundamentalmente, con la "delincuencia económica perpetrada por autores de acomodada posición social". En definitiva, como ya apuntara hace más de 30 años el maestro RODRÍGUEZ MOURULLO, "Algunas consideraciones político-criminales sobre los delitos societarios", ADPCP (t. 37), 1984, p. 677, estamos ante una denominación "de mayor valor literario que rigor científico".

${ }^{5}$ Una cuestión que, pese a su notoria importancia, no ha merecido una especial atención en la doctrina penalista. Hasta donde alcanzo, sólo FEIJOO SÁNCHEZ, ha abordado su examen en una de las partes (pp. 18-33) de su extenso trabajo titulado "Crisis económica y Derecho penal: responsabilidad de inter- 
menos acertada- a diversos interrogantes que, en mayor o en menor medida, polarizan la discusión de la ciencia jurídico-penal en la actualidad y la polarizarán en los próximos decenios.

2. Examino en primer lugar, siquiera brevemente, las graves consecuencias derivadas de la desregulación del mercado financiero y cuestiono la inexistencia hasta la fecha de un "Derecho penal bancario". A continuación, centro mi atención en la función a desempeñar por el Derecho penal, no tanto quizás en la prevención de las cíclicas crisis económico-financieras, como en la segura y necesaria represión de los graves y concretos daños individuales y sociales que bajo su manto habría ocasionado la criminalidad socioeconómica. Pongo de relieve las dificultades y obstáculos a los que se enfrenta esta rama del ordenamiento jurídico en su cruzada en pro de su eficaz detección, persecución y enjuiciamiento. Y, acto seguido, describo, someramente, los rasgos criminológicos más característicos de la delincuencia de cuello blanco con el objeto de poner en valor su incidencia en el racional diseño del sistema de penas con el que prevenirla y, en su caso, castigarla. Convencido como estoy de la necesaria convivencia y colaboración entre penalistas y criminólogos, hago especial hincapié en la utilidad práctica de las "teorías de la oportunidad", por cuanto, a mi juicio, proporcionarían una valiosa información acerca de las condiciones y/o elementos que fomentan la criminalidad económica.

3. Ciertamente, el conocimiento de las razones que mueven al delincuente económico, los mecanismos de autoprotección de que dispone la propia víctima y los entornos que favorecen su comisión ayudarán -o deberían ayudar- al legislador a activar las medidas (de naturaleza extra-penal y/o estrictamente penal) idóneas para, respectivamente, "desactivar" las motivaciones del victimario; aumentar las capacidades autoprotectoras de las víctimas y contrarrestar los efectos criminógenos vinculados a las propias

mediarios financieros por la comercialización de productos de terceros, incremento de insolvencias y de la conflictividad social", en El derecho penal económico y empresarial ante los desafios de la sociedad mundial del riesgo, SERRANO-PIEDECASAS FERNÁNDEZ / DEMETRIO CRESPO (dirs.), Ed. Colex, Madrid, 2010, pp. 11-62. Y, más recientemente, CUGAT MAURI, "La capacidad del Derecho penal ante la mala gestión bancaria", LLP (105) 2013, 21 pp., quien ha centrado su interés en la relevancia jurídicopenal de la práctica bancaria relativa a la "concesión abusiva o irracional de crédito previa al estallido de la burbuja inmobiliaria" (p. 5) y su posible subsunción en los clásicos delitos patrimoniales (estafa/ apropiación indebida) y en el delito societario de administración desleal. Sin embargo, también ha puesto el acento en dos aspectos que considero esenciales a los efectos de este trabajo: a) la inexistencia de un auténtico "Derecho penal bancario"; y b) la ausencia de un debate político-criminal acerca del papel a asignar, en general, al Derecho penal en el control de las crisis económico-financieras y, en particular, en la prevención y represión de las malas prácticas bancarias en tanto factor desencadenante y acelerante de sus negativos efectos sobre el bienestar socioeconómico de la ciudadanía. 
corporaciones públicas o privadas en que los primeros suelen operar. De ahí que destine unas páginas a la crucial y polémica incorporación de la responsabilidad penal de las personas jurídicas (en adelante RPPJ) al objeto de determinar en qué medida constituye la respuesta más eficaz para combatir los efectos criminógenos atribuidos a la empresa en tanto protagonista del tráfico jurídico-mercantil y principal culpable del replanteamiento de la clásica -y en opinión de algunos- vieja Teoría General del Delito. Por último, analizo el papel asignado -o a asignar- a las penas de multa, inhabilitación profesional y prisión en el declarado combate contra esta manifestación criminal. Una problemática que en los últimos tiempos se ha avivado en un sector de la doctrina patria ${ }^{6}$, a buen seguro, como consecuencia del creciente número de escándalos económico-financieros y la amplificación social de sus negativos efectos al hilo de la profunda y persistente crisis que todavía hoy padecemos.

4. Mi interés por el trinomio crisis financiera/intermediación/tutela penal del inversor minorista trae causa de una realidad criminológica que entiendo irrefutable. En la actual crisis ecónomica global -y también de valores- las entidades que prestaron y prestan servicios de intermediación financiera no han actuado como "cortafuegos" - o, en términos jurídico-penales, "garantes"- de los riesgos creados por las sociedades -nacionales e internacionales- emisoras de productos financieros. Más al contrario, se han acabado convirtiendo en las "puertas de entrada de los fraudes provenientes de los mercados financieros" ". Efectivamente, hemos visto -no sin estupor- como dichos agentes han

\footnotetext{
${ }^{6}$ Sirva como ejemplo el trabajo elaborado por BAUCELLS LLADÓS, "Sistema de penas para el delincuente económico", CPC (106) 2012, pp. 143-181, en que denuncia el déficit de atención dispensado a las penas impuestas al delincuente económico desde el intenso debate doctrinal acontecido en los 80 . Para a continuación y partiendo de la revisión del concepto de "Delincuencia económica" y de las causas que la motivan, concluir que existen argumentos de corte preventivo que justifican el recurso a la prisión, así como la incorporación de mejoras en las penas de multa e inhabilitación profesional para combatirla más eficazmente. Artículo que, dicho sea de paso, ha sido incorporado, parcialmente, en la colectánea, titulada La Delincuencia Económica. Prevenir y Sancionar, GARCÍA ARÁN (dir.), Ed. Tirant, Valencia, 2014, en que han intervenido gran parte de los miembros integrados en el área de Derecho penal de la Universidad Autónoma de Barcelona.

${ }^{7}$ Así lo ha puesto de relieve en nuestra doctrina FEIJOO SÁNCHEZ, “Crisis económica...”, p. 18, en un trabajo cuya cita resulta fundamental por ser de los pocos en que se ha alertado de los riesgos penales aparejados a la intermediación financiera y las limitaciones propias de los clásicos delitos patrimoniales y socioeconómicos para combatirlos eficazmente. También PÉREZ CEPEDA, "Retos político-criminales ante la delincuencia transnacional financiera", RP (33) Enero 2014, pp. 144-145, ha hecho especial hincapié, aunque desde otra óptica más crítica, en las malas prácticas desarrolladas en el ámbito económico-financiero, entre las que me interesa destacar a los efectos de esta investigación, las “(...) Operaciones de alto riesgo, con infracción del deber de cuidado de comprobar el riesgo de inversiones en títulos valores, causando dolosamente un perjuicio patrimonial (...) Prácticas fraudulentas o desleales en la comercialización de productos financieros respecto a los inversores".
} 
cooperado necesariamente en la colocación de distintos y variados productos financieros, con y sin conocimiento, de la peligrosidad real que ello comportaba para con el patrimonio individual de sus confiados clientes.

5. Ahora bien, las entidades bancarias, además de colaborar activamente en la transmisión de algunos riesgos jurídico-penales, también han realizado prácticas generadoras de graves e irreversibles perjuicios económicos para con estos últimos. Y, por extensión y/o expansión, la propia solvencia e integridad del conjunto del sistema financiero. Desgraciadamente, resulta sencillo ilustrar esta última aseveración trayendo a colación dos próximos ejemplos. La salida a bolsa de Bankia o la comercialización -masiva e indiscriminada- por las (cuasi) extintas Cajas de Ahorro de las conocidas participaciones preferentes entre un amplio y variado conjunto de consumidores-inversoresminoristas $^{8}$. El primero ha irrogado un grave quebranto económico a los accionistas que han visto como en poco tiempo la cotización de su inversión descendía hasta la mínima expresión. El segundo ha "capturado" los fondos de un elevado número de pequeños ahorradores que, carentes de la formación y experiencia financiera adecuada ${ }^{9}$, pero en la confianza que le merecían sus directores de sucursal ${ }^{10}$, les ha llevado a perder, como mal menor, una parte de lo invertido y, en no pocos casos, la totalidad ${ }^{11}$. Más allá de las gravosas consecuencias económicas y sociales, estos dos escandalosos casos

\footnotetext{
${ }^{8}$ Según ADICAE, desde 1999 hasta 2011 las entidades financieras, particularmente las Cajas de Ahorro, vendieron participaciones preferentes por un total de 30.000 millones de euros a casi un millón de familias comercializándolas "bajo la apariencia de depósitos a plazo fijo con rentabilidad garantizada y además casi siempre ante un perfil de consumidor de edad avanzada que buscaba completar su jubilación con los ahorros de toda una vida" (http://laeconomiadelosconsumidores.adicae.net/index.php?articulo=701). ${ }^{9}$ Como apunta PULIDO BEGINES, "El deber de las entidades financieras de informar al cliente", RDBB (130) 2013, p. 10, nota 3, "El producto financiero conocido como participaciones preferentes es una inversión bancaria destinada a clientes muy cualificados e informados, con capacidad para calibrar su alto riesgo (....) La ausencia de cualificación y la falta de información son frecuentes entre dichos clientes que actuaron con frecuencia amparados en una larga relación de confianza con la entidad...".

${ }^{10}$ Así lo ha puesto de manifiesto de forma muy gráfica ZUNZUNEGUI PASTOR en el informe elaborado para el Defensor del Pueblo (31/01/2013) bajo el título "Comercialización de participaciones preferentes entre clientela minorista", p. 8, cuando señala "La banca comercializa y vende instrumentos financieros, pero lo hace presentándose como asesores ante su clientela. De este modo capturan la confianza del cliente para poder venderle mejor todo tipo de productos financieros".

${ }^{11}$ Así les ha sucedido a quienes compraron las preferentes ofrecidas por las Cajas de Ahorros finalmente nacionalizadas (las extintas Cajamadrid, NovaCaixaGalicia y CatalunyaCaixa). Como señala ZUNZUNEGUI PASTOR en el mencionado informe (pp. 3-4), las entidades no nacionalizadas procedieron a ofrecer el canje de las preferentes por otros instrumentos (p.e., acciones) con la finalidad de aminorar las pérdidas y mantener el cliente. Sin embargo, las nacionalizadas tenían prohibida dicha opción como consecuencia del veto incorporado en el Memorando de la Comisión Europea de 24 de julio de 2012 en que se condicionó las ayudas -o mejor dicho, el rescate financiero-destinadas a la banca española "a la asunción de pérdidas por parte de los titulares de las participaciones preferentes".
} 
contribuyeron además -y de qué manera- a sembrar la desconfianza de la ciudadanía en el sistema bancario y, por ende, de los inversores - nacionales e internacionales- en la "marca España".

\section{Crisis, (des)regulación del sistema financiero y tutela -penal- del inversor minorista: al rescate del "Derecho penal bancario"}

1. La profunda crisis, en su origen financiero-económica y en sus consecuencias políticas y sociales, desencadenada a mediados del 2008 primero en EE.UU y luego en Europa, nos ha enseñado una lección que nunca deberíamos olvidar. La importancia de la regulación nacional e internacional del sistema financiero y el peligro que conlleva la cesión de su gestión a los propios agentes que en él operan. Ciertamente, resulta evidente que la progresiva -y orquestada-desregulación de los mercados financieros y la simultánea relajación de los controles públicos y posterior traslación a agencias y empresas privadas (agencias de rating y grandes auditoras), habrían coadyuvado $-\mathrm{y}$ mucho-al colapso y cuasi quiebra a que se vieron abocadas las economías del "primer mundo"12. Y no menos relevante, también estarían en el epicentro de la consiguiente socialización de las pérdidas mediante el rescate y la nacionalización de diversas y significadas entidades de crédito e inversión acontecidas en España, Europa y EE.UU ${ }^{13}$.

2. De hecho, esta autorregulación y autodisciplina fomentadas en el pasado reciente estarían igualmente en el origen de un considerable número de escándalos financieros dentro y fuera de nuestras fronteras ${ }^{14}$. Escándalos, que bueno sería no obviarlo, han

\footnotetext{
${ }^{12}$ Así lo ha puesto de manifiesto en nuestra doctrina, entre otros, DEMETRIO CRESPO, "El significado político del derecho penal económico", en Crisis financiera y Derecho Penal Económico, DEMETRIO CRESPO / MAROTO CALATAYUD (coords.), Eds. Edisofer/Bdef, Madrid-Montevideo, 2014, p. 7.

${ }^{13}$ En parecidos términos se han expresado, entre otros, GARCÍA RIVAS, "Reflexiones sobre responsabilidad penal en el marco de la crisis financiera", en Crisis financiera y Derecho Penal Económico, DEMETRIO CRESPO / MAROTO CALATAYUD (coords.), Eds. Edisofer/Bdef, Madrid-Montevideo, 2014, p. 36, quien apunta como la crisis financiera ha abocado a varios países al rescate "(...) mediante la inyección de fondos a cambio de brutales medidas de encogimiento del sector público"; a la defraudación de millones de inversores de todas las latitudes al adquirir " paquetes' cuyo valor real era muy inferior al aparente, avalado por las agencias de calificación crediticia" y concluye su reflexión preguntándose en qué medida estas últimas no resultan jurídicamente responsables dada su activa participación en el entramado financiero que propició esta auténtica hecatombe económico-social.

${ }^{14}$ Los escándalos financieros acontecidos a principios del año 2000 y que ocasionaron una generalizada caída de las bolsas y, por ende, unas elevadas pérdidas a todos los inversores, trajeron causa del falseamiento de los balances contables de empresas, algunas de ellas, centrales en su sector (Caso ENRON). Para una breve descripción de los mismos, pueden consultarse, entre otros, el trabajo de QUINTERO OLIVARES, "Los escándalos financieros por falsedad en la contabilidad y la función del derecho penal económico", en
} 
traído consigo en última instancia, entre otras consecuencias, la destrucción de cientos de miles de empleos; un aumento exponencial de desahucios; drásticos recortes en el maltrecho Estado del ( $\mathrm{mal}$ )Bienestar y una profunda pérdida de confianza en las entidades bancarias como principales intermediarias del sistema financiero ${ }^{15}$. Una confianza que, como nos ha demostrado hasta la saciedad la actual crisis, resulta capital para el recto y buen funcionamiento del mercado financiero y, consiguientemente, la propia economía. Sin confianza las posibilidades de financiar y financiarse en el sistema menguan notablemente, aumentan los costes destinados a tal fin, e incluso, de persistir en el tiempo y en el espacio, conduce al agotamiento de las fuentes de financiación poniendo en riesgo la supervivencia del ecosistema económico ${ }^{16}$.

\section{Ciertamente, la reactivación y reforzamiento de los controles formales - estatales y} supranacionales- resulta obligada ante la posición estratégica detentada por los intermediarios financieros y la dosis extra de confianza que precisan estos mercados para el

Derecho penal del consumidor en la Unión Europea, GARCÍA RIVAS (coord.), Ed. Universidad de CastillaLa Mancha, Toledo, 2005, pp. 175 y ss. Y desde una perspectiva más criminológica, resulta de interés el breve -pero revelador- repaso realizado por GEIS, "El delito de cuello blanco como concepto analítico e ideológico", en Derecho penal y criminología como fundamento de la política criminal, LH-Profesor Alfonso Serrano Gómez, BUENO ARÚS / GUZMÁN DALBORA / SERRANO MAÍLLO (coords.), Ed. Dykinson, Madrid, 2006, pp., 317-319, quien, entre otros, comenta los casos "Enron-Arthur Andersen", "WoldCom, Adelphia y Tico" y "HelathSouth" en Estados Unidos, así como los casos "Mannesmann", "Parmalat" y "Muneo Suzuki", acaecidos, respectivamente, en Alemania, Italia y Japón.

${ }^{15}$ En el mismo sentido, se han expresado MARINUCCI / DOLCINI, "Derecho penal 'mínimo' y nuevas formas de criminalidad", (Carnevali Rodríguez, Trad.), RDPC (9) 2002, p. 148, quienes señalan que el falseamiento de balances y de la información económico-financiera de las empresas, entre otras conductas penalmente relevantes, constituyen un atentado a la confianza de los inversores que automáticamente conlleva "la fuga en masa de los capitales extranjeros, la caída de las cotizaciones bursátiles, la ruina de los pequeños ahorradores, la afectación del sistema bancario, los que terminan, algunas veces, con la clausura de las fábricas y el despido de los operarios". En la misma línea se ha pronunciado entre nosotros FEIJOO SÁNCHEZ, "Crisis económica...", pp. 11-12 y 17-18, quien señala cómo la deficiente actuación de los intermediarios financieros en la comercialización de productos generados por terceros se ha traducido en un grave problema de liquidez y de flujo crediticio que, en última instancia, ha motivado un incremento exponencial del número de desempleados.

${ }^{16}$ En este sentido, se han pronunciado, entre otros, GÓMEZ INIESTA, "Aspectos jurídico-administrativos y penales de la falsificación de la información contable de las sociedades anónimas cotizadas", en Derecho penal del consumidor en la Unión Europea, GARCÍA RIVAS (coord.), Ed. Universidad de Castilla-La Mancha, Toledo, 2005, p. 263, quien concluye “(....) la protección de la confianza de los inversores en el correcto funcionamiento del mercado de valores es la mejor garantía de un mercado eficiente"; GALÁN MUÑOZ, "El fraude de inversores del artículo 282 bis CP ¿Una figura protectora del correcto funcionamiento de los mercados financieros en tiempos de crisis?", RDyPP (31) Mayo-Agosto 2013, p. 117, quien destaca igualmente la importancia que nuestros políticos han dado al restablecimiento de la confianza como condición para la recuperación de la economía como si se tratara de un "mantra" que por sí solo nos permitiera salir de la crisis en la que -aún-nos hayamos inmersos. 
adecuado funcionamiento de la economía ${ }^{17}$. De igual forma, ni puede ni debe tolerarse su cesión expresa o tácita a quienes han de ser controlados y vigilados. Un progresivo desmantelamiento de los rígidos controles normativos en los mercados financieros que se justificó por una doble vía. En primer lugar, se adujo que la imposición legal de la obligación de transparencia e información podía sustituirse por su espontánea generación en los mismos mercados. En segundo lugar, se alegó que todo ello contribuiría a fomentar un mayor grado de competitividad entre mercados financieros ubicados en distintos países en tanto manifestación de la inherente globalización de las transacciones económicas. La primera razón adolecía de una ingenuidad supina, por cuanto resultaba harto complicado esperar que las entidades y empresas que operan en dichos mercados publicitaran voluntariamente informaciones o datos que pudieran perjudicarles frente a sus competidores. Y la segunda también porque la-sana-competitividad requiere como condición previa la igualdad de quienes interactúan en el sistema mediante el acceso a equitativos estándares de información que sólo pueden garantizarse mediante su imposición legal ${ }^{18}$.

4. De hecho, la regulación del sistema financiero responde a un doble objetivo. Garantizar la integridad y defensa del propio mercado, y con ello la estabilidad del sistema económico. Y asegurar la propia protección del inversor en general y del inversor minorista en particular. Objetivos ambos que, a su vez, se consiguen actuando normativamente sobre dos ámbitos estrechamente vinculados ${ }^{19}$. Primero, incidiendo en la estabilidad y solvencia de unas entidades como las crediticias condicionadas por la fragilidad de un negocio consistente, a grosso modo, en la captación del capital excedente a corto plazo y su préstamo a un tipo de interés más elevado a quienes están necesitados de financiación ${ }^{20}$. Y, segundo, toda una batería de medidas destinadas a

\footnotetext{
${ }^{17}$ Como ha señalado RECALDE CASTELLS, "Reflexiones sobre los efectos de la crisis en la regulación del sistema financiero", en Estudios de derecho del mercado financiero, LH-Profesor Vicente Cuñat Edo, GONZÁLEZ CASTILLA / MARIMÓN DURÁ (coords), Ed. Universidad de Valencia, Valencia, 2010, p. 725 , esta pérdida de confianza en los intermediarios financieros ha repercutido sobre los propios mercados contrayendo el crédito y extendiendo la crisis a la totalidad del sistema. Además como apunta el citado autor se trata de una desconfianza ad extram (de los clientes hacia las entidades crediticias) y ad intram (de las propias entidades de crédito entre sí).

${ }^{18}$ Sobre esta cuestión, Vid., más extensamente, RECALDE CASTELLS, "Reflexiones...", p. 726 y ss.

${ }^{19} \mathrm{Vid} .$, RECALDE CASTELLS, "Reflexiones...", pp. 725-726.

${ }^{20}$ Un sector que además se caracteriza por su interdependencia porque la crisis de una de sus entidades genera un efecto contagio sobre el resto en el momento en que los ahorradores temen recuperar sus depósitos. De ahí la existencia de una estricta normativa destinada a prevenir el riesgo de insolvencia y su expansión al conjunto del sistema crediticio. Así, por ejemplo, las exigencias en la capitalización de estas entidades que permiten hacer frente a los inherentes riesgos de su negocio o las encaminadas a asegurar la recuperación de los depósitos o inversiones. Al respecto, Vid., el RD 2606/1996, para la regulación de los fondos de garantía de los depósitos o el art. 66 de la LMV para el fondo de garantía de inversiones.
} 
reglar la relación entre las entidades crediticias y los usuarios. Unas medidas entre las que destacaría las siguientes: a) las normas de transparencia y/o información protectoras del cliente-inversor ${ }^{21}$; b) la regulación específica en materia de publicidad financiera ${ }^{22}$; c) la implementación de procedimientos de control interno -los llamados "Códigos de buen gobierno"23-; y d) los requisitos de honorabilidad y profesionalidad impuestos a quienes administran o dirigen entidades financieras ${ }^{24}$.

${ }^{21}$ Más detalladamente sobre esta cuestión, Vid., entre otros, los trabajos de FERRANDO VILLALBA, "Preferentes y otros instrumentos financieros de riesgo: deber de información y buena fe (A propósito de la STS de 18 de abril de 2013)", RAD (2) 2014, pp. 93-115; LA MISMA, "Deber de información sobre el riesgo en el contrato de gestión de carteras: la doctrina del Tribunal Supremo español", Rivista del diritto commerciale e del diritto generale delle obbligazioni, (vol. 112) 2014, pp. 79-109; NAVARRO GANCEDORODRÍGUEZ, "La información a inversores en la administración de valores negociables”, RDMV (9) 2011, pp. 63-120; RECALDE CASTELLS, “Acotación del Derecho de los mercados de 'valores' e 'instrumentos financieros' en tiempos de cambio (supervisión, transparencia y nuevos productos financieros)", RDBB (118) 2010, pp. 9-39; ROJO ÁLVAREZ - MANZANEDA, "Mecanismos jurídicos de protección del cliente inversor frente a las entidades prestadoras de servicios de inversión”, RDBB (114) 2009, pp. 59-117. Y para una panorámica de la situación en Alemania, SCHMIDT, "Desarrollos en la normativa alemana del mercado de valores relativa a la protección del inversor”, RDMV (8) 2011, pp. 9-22.

${ }^{22} \mathrm{La}$ interacción existente entre las obligaciones de información y transparencia impuestas a las empresas de servicios de inversión en el mercado de valores y su canalización por medio de la publicidad se ha positivizado en el apartado $2^{\circ}$ del art. 79 bis de la LMV en que se señala "Toda información dirigida a los clientes, incluida la de carácter publicitario, deberá ser imparcial, clara y no engañosa. Las comunicaciones publicitarias deberán ser identificables con claridad como tales".

${ }^{23}$ También los penalistas han destacado la importancia de estos códigos, entre otros, GÓMEZ INIESTA, “Aspectos jurídico-administrativos....", pp. 266 y ss., eso sí como complemento preventivo de la imprescindible normativa de derecho privado y público en tanto garantía de un óptimo grado de veracidad en la información suministrada y de un eficaz control en la estructura de gobierno de la corporación y de los títulos por ella emitidos. En esta línea se situaría la obligación legal de contar con un comité de auditoría en las sociedades cotizadas contenida en la Ley 44/2002, de 22 de noviembre, de Medidas de Reforma del Sistema Financiero, con funciones en la supervisión de la actividad auditora y la elaboración de las cuentas sociales (art. 47).

${ }^{24}$ Ambas condiciones constituyen uno de los requisitos impuestos a quienes forman parte del Consejo de Administración, Directores Generales o asimilados, así como a quienes ostentan funciones de control interno de las entidades de crédito. Según rezaba en el art. 2 del RD 1245/1995, de 14 de julio, sobre creación de bancos, actividad transfronteriza y otras cuestiones relativas al régimen de entidades de crédito -vigente hasta el 15 de febrero de 2015- "Concurre honorabilidad comercial y profesional, en quienes hayan venido mostrando una conducta personal, comercial y profesional que no arroje dudas sobre su capacidad para desempeñar una gestión sana y prudente de la entidad". Entre los criterios a tomar en consideración para valorar dicha honorabilidad, se hacía expresa referencia-lógicamente- a la expresa comisión de delitos o faltas e infracciones administrativas. El requisito de "honorabilidad" también se aplica a otros operadores del sector financiero tales como las empresas de servicios de inversión (art. 67.1. e. LMV redactado conforme a la Ley 47/2007, de 19 de diciembre en que se procedió a su modificación) o las aseguradoras (art. 5.2. f. del RDL 6/2004, de 29 de octubre en su redacción conforme a lo establecido en la Ley 5/2009, de 29 de junio). Sobre esta cuestión, Vid., infra la nota 155 en que se da cuenta del nuevo marco normativo contenido en los arts. 24, 25 y 26 de la Ley 10/2014, de 26 de junio, de ordenación, supervisión y solvencia de las entidades de crédito. 
5. Es evidente que la proximidad y la confianza, en su día, depositada en ellas y la complejidad propia de los productos financieros, ha convertido, de facto, a las entidades crediticias en asesoras de todo aquel inversor minorista que -legítimamente- busca una mayor rentabilidad para sus ahorros ${ }^{25}$. Es más, la significación de esta actividad es tal que, a la postre, se convirtió en uno de sus principales activos. Lo cual generó en el pasado y sigue generando en el presente un auténtico conflicto de intereses entre sus clientes y la lógica propia de toda empresa cuyo instinto natural le mueve hacia la maximización del beneficio ${ }^{26}$. Un conflicto de intereses que, reitero, condujo a alguna de ellas -en un tiempo no muy lejano- a relajar en exceso los controles internos destinados a detectar la toxicidad y riesgo adicional de los productos comercializados. Y que, en los casos más extremos, les llevó a desentenderse por completo de la auténtica y real peligrosidad de los instrumentos colocados a su clientela ${ }^{27}$.

\footnotetext{
${ }^{25}$ Así lo ha puesto de relieve ZUNZUNEGUI PASTOR, "Comercialización de participaciones...", p. 9, cuyo razonamiento circunscrito eso sí a la comercialización de las preferentes puede servirnos con carácter general para ilustrar esta relación de confianza fraguada entre el pequeño ahorrador y el empleado de la entidad bancaria sita en su barrio, cuando concluye "Desde el lado del ahorrador la búsqueda de rentabilidad para los ahorros es un comportamiento racional. Dejarse llevar por quien se presenta como tu asesor financiero es una conducta diligente. Es el banco quien ha ofrecido el producto y se lo ha recomendado al cliente en una relación asesorada. Del mismo modo que no desconfiamos del médico, tampoco es lógico que desconfiemos de nuestro banco o caja de ahorros. Uno vela por nuestra salud, el otro guarda nuestro dinero". Con carácter general, PÉREZ VALERO, "Delitos societarios e información en las instituciones de inversión colectiva", en Temas de Derecho Penal Económico, TERRADILLOS BASOCO / ACALE SÁNCHEZ (coords.), Ed. Trotta, Madrid, 2004, p. 300, denuncia como la "propia filosofia de la transparencia" en los mercados de valores, parodójicamente, ha derivado en su negación en la medida en que la (sobre)información económico-financiera y su carácter especialmente técnico "hacen que el ciudadano inversor no tenga más remedio que encomendar su capital a una entidad mediadora, la cual es quien pasa a tomar las decisiones de inversión de capitales ajenos en función de una información que puede entender por su capacitación técnica".

${ }^{26}$ No debemos olvidar un dato especialmente significativo para el tema que aquí nos ocupa. Como ha señalado, entre otros, GALLARDO OLMEDO, "Responsabilidad social y protección del inversor minorista en la industria bancaria", en Empresa responsable y crecimiento sostenible: aspectos conceptuales, societarios y financieros, PÉREZ CARRILLO / FERNÁNDEZ-ALBOR BALTAR (coords.), Ed. Aranzadi, Cizur Menor, 2012, p. 266, el porcentaje percibido por las entidades de crédito en concepto de comisión por la venta de tales activos oscila entre el $2 \%$ y el $4 \%$ del precio nominal del producto objeto de la intermediación, convirtiéndolo así en "un negocio muy suculento". De hecho, situado en este escenario, se pregunta muy atinadamente FEIJOO SÁNCHEZ, "Crisis económica...”, p. 20, “¿Qué sucede cuando una inversión perjudicial para los clientes carece de sentido económico y sólo se realiza por lo ventajosas que resultan las comisiones pagadas por la entidad emisora en el ámbito de la intermediación financiera?". En este punto, antes de la reforma operada en 2010, señaló CHOCLÁN MONTALVO, "Protección penal del sistema financiero", LL (4) 2003, p. 1889, que la conducta consistente en la innecesaria multiplicación de las transacciones con el fin de incrementar exponencial y simultáneamente las preceptivas comisiones "puede constituir un comportamiento de administración desleal".

${ }^{27}$ Para una aproximación a esta problemática desde la óptica del Derecho mercantil-civil, pueden consultarse, entre otros, el trabajo de SASTRE CORBACHO, "La regulación de los conflictos de intereses en la MiFID”, RDMV (3) 2008, pp. 227-247.
} 
6. Por otra parte, si nos situamos en el otro lado de la ecuación oferente-demandante, ineludible resulta la cita a la Directiva 2004/39/CE, de Mercados de Instrumentos Financieros - conocida con las siglas en inglés $\mathrm{MiFID}^{28}$ - . Con ella se pretendió fijar un nuevo marco de relaciones, prestando especial atención a los inversores minoristas en su condición de sujetos no profesionalizados y, por ende, más vulnerables ${ }^{29}$. Efectivamente, este déficit de conocimientos económico-financieros dificulta la adquisición racional y razonada de unos productos que, precisamente, con ocasión de la intermediación bancaria, se han popularizado entre amplias capas de la población y alcanzado una dimensión global y transfronteriza ${ }^{30}$. Circunstancias todas ellas que habrían transformado un problema inter partes, en una problemática sistémico-(inter) nacional que, lejos de circunscribirse a la lesión de un determinado patrimonio individual del inversor-ahorrador, resulta idónea para socavar la estabilidad y supervivencia del propio sistema económico ${ }^{31}$.

\footnotetext{
${ }^{28}$ Norma comunitaria que recientemente ha sido reformada por la Directiva 2013/50/UE del Parlamento Europeo y del Consejo, de 22 de octubre de 2013, la denominada MiFID II. Sobre la misma pueden consultarse, entre otros, los artículos de TAPIA HERMIDA, "Modificación de la normativa comunitaria sobre transparencia en el mercado de valores: la Directiva 2013/50/UE", RDBB (33) 2014, pp. 348 y ss.; y FERRANDO VILLALBA, "Extensión y límites del deber de informar al inversor en MIFID II: conflictos de interés y asesoramiento financiero", RDMV (13) 2013, pp. 101 y ss.

${ }^{29}$ No le falta razón a TERRADILLOS BASOCO, "La protección penal del inversor", en Derecho penal del consumidor en la Unión Europea, GARCÍA RIVAS (coord.), Ed. Universidad de Castilla-La Mancha, Toledo, 2005, pp. 134-135, cuando distingue dos tipologías de inversores, los profesionales que poseen un adecuado conocimiento y grado de dedicación y el consumidor-inversor que se limita a ceder sus ahorros a las entidades de crédito con la finalidad de obtener un mejor rendimiento al tradicional depósito bancario; o a GÓMEZ INIESTA, "Aspectos jurídico-administrativos...", p. 265, cuando señala que mientras el inversor-consumidor se haya en una posición de mayor debilidad ante las grandes corporaciones que reclaman el ahorro, el inversor profesional o institucional goza de "capacidad para obtener información directamente o mediante negociación concreta con el emisor".

${ }^{30}$ Como han puesto de relieve en la doctrina penalista, entre otros, CHOCLÁN MONTALVO, LL (4) 2003, p. 1888, con el tiempo el mercado financiero europeo ha evolucionado hacia lo que los analistas denominan "capitalismo popular". Esto es, amplias capas de la población habrían aportado masivamente sus ahorros en forma de inversión quedando el éxito de la decisión económica en manos de intermediarios a quienes se encomendó la gestión. Esta universalización del mercado de capitales trajo consigo una "extensión de riesgo y la posible masificación del perjuicio económico, cuya prevención requiere el establecimiento de adecuados mecanismos de control'. Lo cual, justificaría -continúa el autor-la anticipación de la protección penal antes de la efectiva producción del perjuicio (p. 1898). En el mismo sentido, se ha pronunciado la doctrina mercantilista, entre otros, PULIDO BEGINES, RDBB (130) 2013, p. 9, quien - muy atinadamenteseñala "Si hace sólo unos años era una reducidísima minoría la que recurría a instrumentos financieros como inversión, hoy en día, el desarrollo del "capitalismo popular", ha multiplicado el número de ciudadanos que recurren a estos productos, lo que implica, en último término, una transferencia de los riesgos al ahorrador minorista individual".

${ }^{31}$ En la misma línea, se situaría PULIDO BEGINES, RDBB (130) 2013, pp. 10-11, cuando señala "los riesgos de los mercados financieros ya han dejado de ser una cuestión estrictamente privada que afecta a unos pocos privilegiados con medios para operar en el tráfico; antes bien, se han convertido en un riesgo
} 
7. Ciertamente, el incuestionable peso que han adquirido las entidades bancarias y las instituciones de inversión colectiva en la intermediación financiera, justifica con creces la protección reforzada otorgada al inversor minorista en tanto parte más débil de la relación contraída ${ }^{32}$. Pero, no tanto, el "olvido" del legislador penal y las autoridades (estoy pensando especialmente en la Fiscalía General del Estado) al omitir su proyección -también- al plano de la responsabilidad criminal ${ }^{33}$. Aplaudo el hecho de que la fiscalía haya admitido la posible responsabilidad criminal en que podrían haber incurrido algunos empleados de banca que vendieron estos complejos productos a personas carentes del adecuado perfil financiero para comprarlos ${ }^{34}$. Sin embargo, no comparto en absoluto el hecho de que, todavía a día de hoy, no haya solicitado, igualmente, la apertura de una "causa general" contra las cúpulas directivas de las que partió la orden de captación generalizada e indiscriminada de los clientes cuyos fondos ya estaban depositados en la entidad, así como la posterior extensión a terceros ajenos a su órbita una vez agotado el primero de los caladeros apuntados. Unos fondos que, en última instancia, tenían como destino aumentar, en especial, la ratio de liquidez y

sistémico en nuestras sociedades de capitalismo avanzado. Los abusos y excesos que se cometen en este campo acaban afectando no sólo a los directamente interesados en unos determinados productos, sino a amplios sectores de la población e, incluso, a la sociedad en general, como ha puesto dramáticamente de relieve la profunda crisis económica que venimos sufriendo desde 2007".

${ }^{32}$ Como ha destacado muy acertadamente ZUNZUNEGUI PASTOR, "Comercialización...", p. 9, la intermediación "es forzosa" porque "los clientes no pueden por sí mismos acceder al mercado para comprar el producto del fabricante".

${ }^{33}$ En parecidos términos se ha pronunciado FEIJOO SÁNCHEZ, "Crisis económica...”, p. 18, cuando concluye “(...) Existe una tendencia evidente en la legislación relativa al mercado de valores en hacer recaer sobre las empresas de servicios de inversión el peso de asegurar la efectividad de la protección del inversor, que no parece haber tenido reflejo en la responsabilidad penal". De hecho, la solución al gravísimo problema de las preferentes se ha concentrado, junto en el canje propuesto por las propias entidades, en instrumentos jurídico-privados como son el arbitraje de consumo - un mecanismo de mediación-y las demandas interpuestas en vía civil fundamentadas en la concurrencia de un flagrante vicio en la prestación del consentimiento por el adquirente y, consiguientemente, la petición de nulidad del contrato suscrito. En efecto, sólo muy excepcionalmente, se ha formulado la correspondiente querella ante unos hechos que cualquier estudiante medio de derecho, calificaría como constitutivos de un delito de estafa (art. 248 $\mathrm{CP}$ ) agravada (arts. $250.4^{\circ}, 5^{\circ}$ y $6^{\circ} \mathrm{CP}$ ). Sobre este particular se ha mostrado especialmente contundente GARCÍA RIVAS, "Reflexiones...", p. 42, quien concluye "la persecución-penal-de unas conductas estructuralmente fraudulentas (...) queda en general derivada hacia la mera responsabilidad civil, como de un mero incumplimiento contractual se tratara, incentivando así los mecanismos de derecho privado en auge frente a la pura responsabilidad penal, reclamada por un daño grave y masivo a millares de ciudadanos cuyos ahorros quedaron dilapidados por alguien, al otro lado del Atlántico, que decidió incrementar sus beneficios titulizando hipotecas basura y distribuyéndolas por todo el mundo". Yo también comparto su esperanza de que en las causas ya abiertas y las venideras se juzguen unas conductas que superan con mucho el riesgo civil para situarse de plano en la órbita penal. Eso sí, respetando todas y cada una de las garantías sustantivo-procesales aplicables a cualquier ciudadano.

${ }^{34}$ Vid., GARCÍA RIVAS, "Reflexiones...”, pp. 41-42. 
solvencia de las Cajas de Ahorro que, a raíz de los "años de vino y rosas en el ladrillo" y la eclosión de la burbuja inmobiliaria con motivo del escándalo de las hipotecas subprime, se encontraban, eufemísticamente hablando, en una situación financiera "muy comprometida" 35 .

8. Ahora bien, sorprende que constatado el innegable protagonismo de estas entidades en el sistema financiero y su indiscutible contribución a la crisis, no exista todavía en España un específico cuerpo de ilícitos penales encaminados a combatir los riesgos derivados de la actividad bancaria en general $^{36}$. Y, muy en particular, los comportamientos fraudulentos o gravemente negligentes desplegados en el desempeño de su función intermediadora $^{37}$. O dicho con otras palabras, contrasta el desarrollo experimentado por el Derecho penal societario, de la competencia o bursátil ${ }^{38}$ y la simultánea opción político-criminal de seguir relegando la persecución y sanción de la actividad bancaria al estricto ámbito del Derecho administrativo sancionador ${ }^{39}$. De ahí que en este trabajo me plantee la posibilidad de rescatar un subsector del Derecho penal, hasta ahora, no

\footnotetext{
${ }^{35}$ Tanto es así que, siete años después de "desatarse la tormenta financiera perfecta", estas entidades que ocupaban el $50 \%$ del espectro bancario español han desaparecido cuasi por completo, quedando dos cuyo peso específico en el conjunto es meramente testimonial (Caixa Ontinyent y Colonya Caixa Pollença).

${ }^{36}$ Un ámbito que, según alcanzo, únicamente ha merecido dos estudios en que se ha abordado la sistematización de las infracciones penales que tendrían a las entidades bancarias como autoras y víctimas. $\mathrm{Me}$ refiero a los artículos elaborados, a mediados de los años 90, por SILVA SÁNCHEZ, "El Derecho penal bancario", AP (48/26 dic) 1994, pp. 901-917 y, ya en pleno siglo XXI, por NIETO MARTÍN, "Derecho penal y contratación bancaria", en La contratación bancaria, GADEA SOLER / SEQUEIRA MARTÍN (coords.), Ed. Dykinson, Madrid, 2007, pp. 1-47.

${ }^{37}$ Como expuse al inicio de esta investigación autores como FEIJOO SÁNCHEZ, "Crisis económica...", pp. 18 y 20, han alertado acerca de la progresiva tendencia a la transferencia de riesgos desde las entidades financieras a agentes más débiles y la necesidad de "girar necesariamente la vista" a un sector como el de los intermediarios del sistema bancario que tradicionalmente "no ha estado sometido a especiales riesgos penales".

${ }^{38}$ Resulta por ello lógico el argumento ofrecido por SILVA SÁNCHEZ, AP (48/26 dic) 1994, cuando a mediados de los 90 señalaba que la inexistencia de un auténtico "Derecho penal bancario" no constituía una excepción en nuestro sistema dada la ausencia, en aquel momento histórico, de un verdadero "(...) Derecho penal societario, de un Derecho penal de la competencia (...) y un incipiente Derecho penal bursátil...” (p. 902).

${ }^{39}$ Como han destacado los pocos autores que se han ocupado de esta cuestión, la decisión político-jurídica de desplazar la protección de la estabilidad del sistema bancario y los intereses de los consumidores-ahorradores al Derecho administrativo sancionador, explicaría tanto la inexistencia de un específico "Derecho penal bancario" como la escasa atención que, hasta la fecha, le ha dispensado la doctrina penalista. Lo cual, contrastaría con lo ocurrido en países de nuestro entorno geográfico-político-jurídico como Francia, Italia o Alemania, donde sí que cuentan con este conjunto de infracciones específicamente penales. En este sentido, se han pronunciado, SILVA SÁNCHEZ, AP (48/26 dic) 1994, pp. 901-904; NIETO MARTÍN, "Derecho penal...", pp. 2-4; y más recientemente FEIJOO SÁNCHEZ, "Crisis económica...", pp. 16-17, quien ha reiterado tanto la competencia exclusiva del Derecho administrativo en la prevención de las "crisis bancarias" como la inexistencia de "un Derecho penal especifico de la actividad bancaria".
} 
explorado por el legislador -y muy poco escrutado por la doctrina- como el "Derecho penal bancario".

9. Y digo "no explorado" porque -insisto- el legislador, pese a la hiperactividad penal que le aqueja y el apego que tiene al Derecho comparado como fuente inspiradoralegitimadora de sus recurrentes reformas, no ha creado todavía ese subgrupo de delitos focalizado a prevenir y reprimir "las actividades delictivas cometidas desde entidades bancarias" $"$. Ahora bien, mi selectivo interés se concentra en las conductas lesivas de estas corporaciones con respecto al patrimonio individual de los ahorradores-inversores minoristas. Comportamientos que de multiplicarse acaban por resultar idóneos para menoscabar el propio orden socioeconómico en su conjunto. Si bien no quisiera pasar por alto que también las conductas en que los bancos se erigen en víctimas pueden afectar, debido al efecto contagio, a la propia estabilidad del sistema financiero como así ha sucedido en la última gran crisis.

10. Como en su día puso de relieve Silva SÁnChEz ${ }^{41}$, los delitos bancarios pueden sistematizarse en torno a tres grandes grupos. En primer lugar, aquellos en que la entidad bancaria es la víctima y el autor es una persona ajena a la misma (ejemplo paradigmático, la llamada "estafa de crédito"). En segundo lugar, los hechos que teniendo igualmente a esta entidad como víctima, el autor forma parte de su propia estructura directiva (por ejemplo, el delito de administración desleal). Y, en tercer lugar, los comportamientos delictivos en que el banco es el autor (o en puridad, las personas físicas que lo administran) y las víctimas se situarían extramuros como sucede en el caso de los inversores (actuales y potenciales) y el resto de entidades de crédito. O como el propio autor advierte, también podrían ubicarse en el propio banco (ad intram) como acontece en el supuesto de los accionistas que ven como el valor de sus títulos descienden con motivo de una desleal administración por parte de quienes lo dirigen. De tal forma que este último y el segundo de los grupos enumerados podrían superponerse.

11. No alcanzo a entender cómo es posible que, pese a las experiencias acumuladas en el pasado ${ }^{42}$ y los estragos económicos y sociales ocasionados en la presente crisis, nuestro ufano legislador ni tan siquiera se haya planteado la introducción de un delito

${ }^{40}$ Vid., FEIJOO SÁNCHEZ, “Crisis económica....”, p. 20.

${ }^{41}$ Vid., SILVA SÁNCHEZ, AP (48/26 dic) 1994, pp. 901-902.

${ }^{42}$ Para un estudio desde la perspectiva penal de las sucesivas crisis bancarias acontecidas a finales de los 70 y principios de los 80, resulta de obligada consulta el trabajo elaborado por RODRÍGUEZ MOURULLO, "Aspectos penales de las crisis bancarias", en Aspectos jurídicos de las crisis bancarias, GARCÍA VALDÉS (dir.), Ed. Banco de España, Madrid, 1988, pp. 279 y ss. También contenido en la obra titulada Estudios de Derecho penal económico, Ed. Civitas/Thomson Reuters, Cizur Menor, 2009, pp. 13 y ss. 
de administración fraudulenta en la intermediación financiera ${ }^{43}$. Y, por el contrario, ha tenido a bien incorporar el llamado "fraude de inversores" que, más allá del "publicitario" nomen iuris elegido, sólo proporciona una tutela parcial y, consiguientemente, insuficiente al ahorrador-inversor-consumidor de productos financieros. Eso sí, como contrapartida, garantizará un buen puñado de problemas concursales con otros ya previstos como el delito societario de falsedad en las cuentas anuales contenido en el art. 290 del CP. Un ilícito penal con el que el "fraude de inversores" compartiría buena parte del elenco de conductas típicas que, en principio, estaban "reservadas" para esta "original" figura alumbrada en la penúltima gran reforma del Código Penal perpetrada en la LO 5/2010.

12. Se trata de un delito que, pese a su nula aplicación práctica desde su incorporación en 2010, ha despertado un relativo interés en nuestra doctrina ${ }^{44}$. Está ubicado

${ }^{43}$ En la línea del art. 54 de la propuesta de Eurodelitos formulada por el grupo de expertos encabezados por el gran penalista alemán KLAUS TIEDEMANN. Precepto redactado por el Profesor FOFFANI y cuyo tenor literal es el siguiente: "Será castigado.... Quien en la realización de servicios de intermediación financiera ocasione un perjuicio de especial gravedad a sus clientes, si ha actuado en una situación de conflicto de intereses y ha abusado de sus competencias, violado una determinada obligación o de cualquier modo se ha comportado de manera contraria a los principios de una cuidadosa prestación de servicios en la intermediación de servicios. Lo dispuesto en el art. 51.3 será de aplicación en estos casos". Como apunta el propio FOFFANI, "Delitos bancarios y bursátiles", en Eurodelitos. El Derecho Penal económico de la Unión Europea, TIEDEMANN (dir.), NIETO MARTÍN (coord.), Ed. UCyM, Cuenca, 2004, p. 116, este delito tiene como objetivo combatir "Los peligros que amenazan el correcto funcionamiento de los mercados de capitales -y sobre todo a los concretos intereses del inversor individualmente consideradoderivados de conflictos de intereses entre intermediarios financieros y clientes y entre distintos clientes (...) Este tipo penal representa una combinación ideal que (...) aúna el modelo general de la Untreue de tradición germánica con otros modelos sectoriales de incriminación que son típicos del Derecho penal especial de los ordenamientos latinos".

${ }^{44}$ Además de los comentarios y manuales al uso, destacaré, entre otras, las contribuciones de ARMAZA ARMAZA, "Aspectos problemáticos del delito de falsedad en la inversión en los mercados de valores", en Nuevos instrumentos jurídicos en la lucha contra la delincuencia económica y tecnológica, ROMEO CASABONA/ FLORES MENDOZA (eds.), Ed. Comares, Granada, 2012, pp. 85-109; GALÁN MUÑOZ, RDyPP (31) Mayo-Agosto 2013, pp. 115-150; LLEDÓ BENITO, "La estafa de inversores en relación con el delito de publicidad engañosa", en Derecho y consumo: aspectos penales, civiles y administrativos, MORILLAS CUEVA (dir.), Ed. Dykinson, Madrid, 2013, pp. 255-312; MARTÍNEZ-BUJÁN PÉREZ, Estafa de inversores y de crédito (El art. 282 bis del Código Penal), Ed. Tirant, Valencia, 2012; MORALES GARCÍA, "Fraude de inversores (art. 282 bis)", en La reforma de 2010, QUINTERO OLIVARES (dir.), Cizur Menor, 2010, pp. 231-240; PUENTE ABA, "El artículo 282 bis del Código Penal: las falsedades en la inversión en los mercados de valores", RDPC (7) 2012, pp. 51-80. También resultan de interés para contextualizar el alumbramiento del "fraude de inversores", algunos trabajos anteriores como, por ejemplo, los elaborados por GÓMEZ INIESTA, “Aspectos jurídico-administrativos...” pp. 261-296; TERRADILLOS BASOCO, "La protección...", pp. 133-156; o VILLACAMPA ESTIARTE, "Las falsedades contables en el proyecto de ley orgánica de modificación del Código Penal de 2007", en La adecuación del derecho penal español al ordenamiento de la Unión Europea: la política criminal europea, ÁLVAREZ GARCÍA/ MANJÓN-CABEZA OLMEDA/VENTURA PÜSCHEL (coords.), Ed. Tirant, Valencia, 2009, pp. 427-468. 
en la Sección $3^{\mathrm{a}}$ ("De los delitos relativos al mercado y a los consumidores") del Capítulo XI ("De los delitos relativos a la propiedad intelectual, al mercado y a los consumidores") del Título XIII ("Delitos contra el patrimonio y contra el orden socioeconómico") y se estructura en forma de triple escalón. Un tipo básico en el que se describe el núcleo del injusto consistente en el falseamiento del folleto informativo $\mathrm{u}$ otros documentos financiero-contables de la sociedad emisora con la finalidad de captar inversores (párrafo $1^{\circ}$ ). Un subtipo agravado aplicable a los supuestos de producción de un efectivo perjuicio económico al inversor (párrafo $2^{\circ}$ primer inciso). Y una hiperagravación que, en un claro paralelismo con el tráfico de drogas, se activa de ocasionarse un perjuicio económico de "notoria importancia" (párrafo $2^{\circ}$ inciso final). A efectos de cuantificación penológica, se castigan, respectivamente, con una pena -única- de prisión (1 a 4 años), a imponer en su mitad superior de concurrir el subtipo agravado y una pena acumulativa de prisión ( 1 a 6 años) y multa (6 a 13 meses) de activarse la hipercualificación.

13. Es posible que un espectador confiado y poco avezado estime que esta enésima ampliación del Código penal tuvo como finalidad proporcionar una tutela extra al inversor en su faceta de consumidor de instrumentos financieros. Es decir, que permitiría, primero, sancionar penalmente las prácticas de intermediación que dolosa o imprudentemente pongan en peligro su patrimonio individual. Y, de generalizarse el comportamiento, sancionar a continuación las graves alteraciones del mercado financiero al que estos micro inversores acuden -legítimamente- buscando una mejor rentabilidad para sus ahorros. Pues bien, siento desilusionar a nuestro querido hombre medio y advertirle que estos comportamientos no resultarían típicos a los efectos del delito contenido en el art. 282 bis $\mathrm{CP}^{45}$. O, a lo sumo, lo serán sólo en concepto de participación en el

\footnotetext{
${ }^{45}$ Como ha puesto de relieve FEIJOO SÁNCHEZ, "Crisis económica...", p. 26, la conducta descrita en el art. 282 bis CP vendría a suplir alguna de las carencias de la clásica estafa, pero sólo permitiría responder a los intermediarios financieros a título de participación. Además, continúa el citado autor, desplazaría por su especialidad y mayor penalidad a los delitos de publicidad engañosa (art. $282 \mathrm{CP}$ ) y falseamiento de la información societaria (art. 290 CP) que, hasta su introducción, se erigían en los principales "candidatos" para dispensar una protección penal al inversor. En la misma línea se han pronunciado, entre otros, MARTÍNEZBUJÁN PÉREZ, Estafa..., p. 141, para quien los “meros intermediarios" carentes de facultades ejecutivas en torno a la veracidad de la información económico-financiera no pueden ser incluidos en el concepto de "administrador de hecho" y, consiguientemente, se situarían "al margen del circulo de posibles autores"; MORALES GARCÍA, "Fraude...", p. 239, quien categóricamente concluye "Quedarían fuera del alcance del precepto, en cambio, los meros intermediarios financieros que carecen de atribuciones reales sobre el folleto o el resto de informaciones típicamente descritas"; GARCÍA RIVAS, "Reflexiones...", p. 39, quien, al hilo de la posible responsabilidad penal en que podrían haber incurrido las agencias de calificación crediticia en su condición de intermediarias financieras, concluye que lo impide la restricción del círculo de autores a los administradores de hecho o de derecho de la sociedad emisora de los valores.
} 
hecho de otro, esto es, el emisor de los títulos valores en cuestión. Una decisión que, visto el recurrente desinterés mostrado por el legislador en la creación de un auténtico "Derecho penal bancario", puede calificarse de lógica.

14. No me resisto a concluir este epígrafe sin denunciar un olvido -felizmente subsanado $^{46}$ - que entiendo lamentable. Me estoy refiriendo a la omisión del art. 282 bis en la querella interpuesta por UPyD ante el Juzgado Central de Instrucción $n^{\circ} 4$ de la Audiencia Nacional contra los Consejeros de las entidades Bankia, S.A. y Banco Financiero y de Ahorros, S.A y las propias sociedades citadas ${ }^{47}$. Nadie lo sabe, claro está, pero difícilmente en el futuro pueda darse un supuesto semejante al "Caso Bankia"48 en el que cual guante encajar el comportamiento típico descrito en el actual art. 282

\begin{abstract}
${ }^{46}$ Así lo fue gracias a su inclusión en la querella interpuesta por la plataforma ciudadana "15MpaRato" también admitida y acumulada por el Titular del Juzgado de Instrucción $n^{\circ} 4$ de la Audiencia Nacional en el Auto dictado en fecha 10 de julio de 2012. Además del Ministerio Fiscal -que por cierto se opuso a su admisión-, están personadas en esta causa (Diligencias Previas n 59/2012), UPyD, en su condición de acusación popular, y la citada plataforma que actuaría como acusación particular al interponer la querella en nombre de 10 pequeños inversores que, con motivo de la salida a bolsa de Bankia, perdieron, presuntamente, un total de 106.000 euros. Al igual que ya sucediera con la formulada por el mencionado partido político, se han querellado contra la propia entidad y quienes formaban parte del Consejo de Administración en el momento en que se tomó dicha decisión. Eso sí, como decía, a diferencia de la anterior, se reflejó, junto a la "estafa en documento mercantil, falsificación de cuentas e intervención fraudulenta y desleal", el "delito de falsedad de contabilidad para captar capitales en los mercados secundarios". Ello abre las puertas a un futuro pronunciamiento de la Audiencia Nacional (Sala de lo Penal) acerca de la relevancia jurídico-penal de tales hechos y la posible subsunción de los mismos en la conducta descrita -también-en el art. 282 bis CP. Para ello las acusaciones deberán sortear todavía muchos obstáculos, de ahí que tengamos "Causa Bankia" para mucho rato.

${ }^{47}$ Esta "llamativa" omisión fue destacada tanto por el Ministerio Fiscal en su informe sobre la admisión de la querella como por el propio Magistrado-Juez y algunos penalistas, entre otros, MARÍN DE ESPINOSA CEBALLOS, "La responsabilidad penal de las personas jurídicas: el caso Bankia", LLP (102) mayo-junio 2013, pp. 1-19; y SILVA SÁNCHEZ, "Crisis financiera y Derecho penal”, opinión expresada en el blog ¿Hay derecho? publicado en fecha 25/06/2012.

${ }^{48}$ Aunque en la realidad, digamos, periodística, sí que existe un "Caso Bankia", técnicamente no es así. En el plano estrictamente procesal, contamos con una pluralidad de causas que cual "bomba de fragmentación o racimo" tienen su epicentro en la extinta "Caja Madrid" o la alumbrada "Bankia". Así, entre otros y hasta el momento, contamos con el "Caso de las Preferentes"; el "Caso de la Venta del Banco de Miami" (que motivó, por cierto, la inhabilitación del Juez Elpidio Silva, condenado por el TSJ de Madrid como autor de un delito continuado de prevaricación judicial y que ha sido confirmada por el TS en su Sentencia 22/2015, 21-04, Pte. Martínez Arrieta); el "Caso de la salida a bolsa de Bankia"; y, más próximo en el tiempo, el "Caso de las Black Cards" en el que confluyen prácticas iniciadas por los Administradores de "Caja Madrid" y, presuntamente, continuadas por los nuevos gestores de "Bankia". Un caso este el de "Bankia" que en una nueva derivada está mutando -o podría mutar-parcialmente hacia el mediáticamente conocido como "Caso Rato". Todo dependerá de cómo se resuelva finalmente la disputa abierta entre las distintas instancias judiciales -y fiscales- acerca de la (in)competencia de los Juzgados de Castilla o de la Audiencia Nacional.
\end{abstract}


bis $\mathrm{CP}$, un delito cuyo recorrido en la praxis -ya adelanto- se me antoja entre corto y muy corto ${ }^{49}$.

\section{Prevención y castigo de las -cíclicas-crisis económicas y sus efectos: de actitu- des y eficacias en la persecución y enjuiciamiento de los delitos socioeconómicos}

1. Llegados a este punto, quisiera dar respuesta a un par de interrogantes que entiendo esenciales: ¿Qué función ocupa o debería ocupar el Derecho penal en la prevención de las cíclicas crisis económicas? ¿Y en el posible castigo de los distintos comportamientos lesivos perpetrados antes, durante y después de su formal declaración? Pues bien, en relación con la primera de las preguntas formuladas -todavía hoy-albergo alguna duda sobre la idoneidad del Derecho penal como eficaz instrumento en la evitación de estos terremotos consustanciales al capitalismo ${ }^{50}$. Dudas que, a decir verdad, progresivamente se me han ido despejando al tiempo que, en tanto ciudadano, observaba los estragos causados por la crisis financiera. Y lo que resulta si cabe más relevante, al comprobar el vergonzante papel protagonizado por las instituciones que, como el Banco de España

\footnotetext{
${ }^{49}$ Muy resumidamente, la querella pivotaría sobre cuatro hechos esenciales: a) el principal, la salida a bolsa de Bankia en que, según consta en la querella, los consejeros de Bankia habrían distorsionado las cuentas de ambas entidades con el propósito de presentar una mejor situación patrimonial a la realmente existente y ganarse así la confianza de los inversores (hecho que, sobre el papel, se ajusta bastante al tenor literal del art. 282 bis párrafo $1^{\circ}$ ); b) la progresiva descapitalización de la entidad mediante una política ruinosa de inversiones que habría ocasionado un quebranto económico a la totalidad de sus accionistas; c) la manipulación de la información posterior a la propia salida a bolsa de la entidad con el fin de mantener el precio de cotización de las acciones -y ratios de solvencia- y alterar así el normal funcionamiento del mercado y el sistema económico; y d) la política de remuneraciones en una entidad que había recibido ayudas públicas del FROB, o más concretamente, las prejubilaciones y blindajes (auto)concedidos por los consejeros querellados. Hechos que fueron, respectivamente, calificados por el querellante como constitutivos de un delito de falseamiento de las cuentas anuales (art. 290 CP); un delito de administración desleal o fraudulenta (art. 295); un delito de maquinación para alterar el precio de las cosas (art. 284 CP) y, por último, un delito de apropiación indebida o administración desleal (art. $252 \mathrm{CP}$ ).

${ }^{50}$ Muy categórico se ha mostrado en este punto FEIJOO SÁNCHEZ, “Crisis económica....”, p. 13, para quien "el Derecho penal económico no es instrumento idóneo para controlar las dinámicas propias de la economía, al igual que, como sistema basado en la responsabilidad individual, no representa una respuesta institucional idónea para resolver por si mismo problemas sistémicos -y concluye-El punto de partida contrario conduce a una ilegitima y patológica 'administrativización del Derecho penal', en el que éste se convierte en una sistema de gestión ordinaria o primaria de macrorriesgos, asumiendo razonamientos propios del Derecho administrativo". En las antípodas de este planteamiento se situaría en nuestra doctrina PÉREZ CEPEDA, RP (33) Enero 2014, p. 155, quien, no sin cierta dosis de voluntarismo, concluye “(....) una ampliación o extensión del ámbito de intervención penal podría estar justificada en los delitos contra el orden socioeconómico y en los delitos financieros, incluso sería "soportable" la falta de un referente valorativo sobre la gravedad de los hechos descritos en el tipo, la flexibilización del aparato garantístico y el sistema de imputación".
} 
o la CNMV, no sólo debieron alertarnos de la misma y de sus efectos, sino que tenían y tienen respectivamente encomendada la -capital- tarea de supervisar, requerir y sancionar a cuantas entidades operan en los mercados bancario y de valores ${ }^{51}$.

\section{Lo acontecido en nuestro sistema financiero ${ }^{52}$ deviene prueba de cargo suficiente} para fundamentar la ineficaz actuación de los supervisores institucionales -cuyos presidentes, dicho sea de paso, son nombrados directamente por el ejecutivo- y justificar la intervención también penal en el ámbito bancario. Un sector que insisto no sólo ofreció sus propios productos financieros (los denominados híbridos, esto es, preferentes y deuda subordinada), sino que compró y comercializó instrumentos tan "solventes" como los empaquetados -en descriptiva expresión-por Lehman Brothers o Madoff-por citar los más conocidos-. Contribuyendo así, y de qué manera, a alimentar la burbuja inmobiliaria cuyo estallido causó las gravísimas consecuencias económicas y sociales de todos conocidas.

\section{El Derecho penal constituye un instrumento especialmente idóneo para prevenir y} castigar las malas prácticas realizadas por todas aquellas empresas que realizan labores comercializadoras de productos financieros ajenos ${ }^{53}$. Ciertamente, quizás carezca de

\footnotetext{
${ }^{51}$ De otra opinión FEIJOO SÁNCHEZ, “Crisis económica....”, p. 17, quien argumenta “(...) Curiosamente, la experiencia española a raíz de la presente crisis económica ha demostrado que una buena gestión del sistema bancario por parte del Banco Central puede hacer que éste resista mejor la crisis que otros países con una amplia intervención punitiva en materia bancaria, dejando en evidencia la falta de necesidad de una ampliación del ordenamiento jurídico-penal en este sentido. Aquí no ha habido nacionalizaciones ni la intervención del sistema financiero (salvo los casos de la Caja de Ahorros de Castilla-La Mancha y de Cajasur) ni la necesidad de una entrada generalizada de recursos públicos en el capital de instituciones financieras. El sistema español tiene problemas que poco a poco van aflorando, pero ninguno de ellos se hubiera resuelto o aminorado con más Derecho penal bancario". En descargo del citado autor, debe precisarse que lo escribió a principios del 2010. De aplicar, digamos, una perspectiva ex post, quizás todo lo ocurrido con posterioridad le lleva a reformular lo dicho.

${ }^{52}$ Esto es, la práctica desaparición de las antiguas Cajas de Ahorro y la inyección, en el peor de los casos, de más de 100.000 millones de euros de euros. Y, en el "mejor" de los casos, más de 60.000 (de los que 40.000 millones han sido aportados por el fondo de rescate patrocinado por la Troika) que se han destinado, esencialmente, al rescate de las siguientes entidades crediticias: 22.424 millones a Bankia; 12.052 a Catalunya Banc (la antigua Caixa Catalunya); 9052 a NCG Banco (entidad resultante de la fusión de las antiguas Cajas de Ahorros Gallegas); 5498 al extinto Banco de Valencia (comprado por CaixaBanc) y los 5249 aportados a la Caja de Ahorros del Mediterráneo (CAM) tras su adquisición por Banco Sabadell.

${ }^{53}$ Disiento en este punto de FEIJOO SÁNCHEZ, "Crisis económica...”, p. 19, cuando concluye “(...) el Derecho penal no es un instrumento idóneo para controlar a las entidades de inversión colectiva o empresas de servicios de inversión que actúan como intermediarias" y califica a continuación de satisfactorias la compensación "voluntaria" por la entidad financiera de las pérdidas contraídas por los clientes que adquirieron productos "empaquetados" por Lehman Brothers o algunos bancos islandeses, así como el pago de la indemnización una vez compelidas por los fallos dictados en la jurisdicción civil "incluso en caso de gestiones negligentes o poco diligentes o cuando el intermediario no sabe muy bien qué es lo que está
} 
aptitud para evitar las cíclicas crisis financiero-económicas. Pero, desde luego, debería servir para combatir sus negativas consecuencias en el plano individual e institucional y castigar así a quienes han lesionado, respectivamente, el patrimonio personal de los inversores y puesto en peligro - concreto- la estabilidad del orden socioeconómico. Nada impide que se investiguen y, en su caso, se sancionen penalmente los comportamientos protagonizados por aquellos responsables de bancos que, habiendo realizado inversiones en productos financieros de ínfimo valor real o ruinosas promociones inmobiliarias, han perjudicado seriamente los intereses económicos de la entidad que representaban y, por ende, a sus socios, inversores y acreedores ${ }^{54}$. El hecho de que la crisis pueda tener su origen en un fallo sistémico del capitalismo no es óbice para descartar ad totum la posible individualización y responsabilidad -también- penal de quienes contribuyeron o se aprovecharon de ella, obteniendo así un beneficio particular o para un tercero en perjuicio de otros muchos. De ahí que, como ha puesto de relieve Mir Puig, resulte entendible la demanda de una mayor intervención penal destinada a reforzar la tutela del sistema financiero en respuesta al "reconocimiento de que la crisis financiera se debió en parte a la falta de control y al ocultamiento fraudulento de los riesgos inherentes a determinados productos financieros" ${ }^{55}$.

4. En todo Estado Social y democrático de Derecho que se precie, el principio de igualdad material obliga a los poderes públicos a remover todos los obstáculos para garantizar la efectiva y real igualdad de los sujetos que concurren en un determinado

comercializando". Es posible que la cuestión radique en que, en puridad, no estamos ante meras gestiones negligentes o poco diligentes, sino más bien doloso eventuales y, por tanto, susceptibles de ser calificadas como constitutivas de un delito de estafa en los supuestos más graves. Posibilidad que no pudo plantearse porque, claro está, las entidades reaccionaron diligentemente asumiendo las pérdidas o sustituyendo los productos en cuestión por otros más fiables a la par que rentables. Con ello, a buen seguro, evitaron que alguno de sus clientes más enojados e ilustres pudieran querellarse contra ellas sometiendo a quienes las dirigen al escarnio público y a la estigmatización propia del proceso penal y la consiguiente dosis de desprestigio para la propia entidad financiera y, por extensión, al conjunto del sistema.

${ }^{54}$ De ahí que comparta plenamente la reflexión del ilustre penalista alemán SCHÜNEMANN, "La denominada crisis financiera: ¿un reto para la justicia?”, (Yanes Yanes/González Navarro, Trads.), en Nuevos instrumentos jurídicos en la luch a contra la delincuencia económica y tecnológica, ROMEO CASABONA / FLORES MENDOZA (eds.), Ed. Comares, Granada, 2012, p. 33, cuando concluye "El análisis de la penúltima y de la presente debacle financiera desde una perspectiva jurídico-penal posee por tanto un significado práctico también para el futuro (...) y tampoco puede el análisis verse bloqueado por la tesis de que se tiene que tener en cuenta que las consecuencias colectivas y globales de la crisis financiera no se pueden combatir o evitar a través de procesos penales contra individuos (...) la prueba de si el particular director del banco ha perjudicado a su propio banco a través de inversiones en títulos de escaso o ningún valor y de si, por ello, es penalmente responsable. Por este motivo, no hay ninguna razón seria para bloquear a lamine la investigación penal".

${ }^{55}$ Vid., MIR PUIG, Bases constitucionales del Derecho penal, Ed. Iustel, Madrid, 2011, p. 32. 
sector $^{56}$. Y más si cabe en los supuestos en que se trata de ofrecer protección a una colectividad de personas cuyos intereses pueden resultar gravemente afectados por unas entidades como las financieras que ocupan una preeminente posición fáctica en el sistema. La intervención -complementaria-del Derecho penal en la protección del orden socioeconómico, lejos de paralizar la actividad ${ }^{57}$, contribuye a compensar la asimetría de información de quienes acceden a los mercados financieros ${ }^{58}$. Lo que acaba redundando en la multiplicación de los intercambios económicos y en una óptima financiación de las empresas y particulares. De hecho, a mi juicio, la tutela penal favorece, en última instancia, el efectivo y libre desarrollo de la personalidad de los ciudadanos en la esfera económico-patrimonial, coadyuvando así a ampliar las cuotas de libertad e igualdad en la libre disposición de sus bienes.

5. Ahora bien, la eficaz prevención y sanción de los delitos económicos requiere como premisas previas: a) una adecuada selección del bien jurídico-penal a proteger; b) una precisa delimitación ad intram y ad extram del comportamiento objeto de sanción que impida, respectivamente, solapamientos con otras conductas típicas y los correspondientes ilícitos administrativo-mercantiles ${ }^{59}$; y c) una ponderada descarga en este grupo

${ }^{56}$ En la misma línea se han pronunciado, entre otros muchos, CHOCLÁN MONTALVO, LL (4) 2003, p. 1886, quien señala como en este ámbito el Derecho penal cumpliría una función preventiva que "no puede asumir la mera responsabilidad civil reparadora ex post del daño"; TERRADILLOS BASOCO, "Financiarización económica y política criminal", en El Derecho penal económico y empresarial ante los desafios de la sociedad mundial del riesgo, SERRANO-PIEDECASAS / DEMETRIO CRESPO (dirs.), Ed. Colex, Madrid, 2010, p. 131, para quien, en general, la intervención penal en materia socioeconómica tendría el aval implícito del Estado Social de Derecho, pero no podría traducirse en una "indiscriminada criminalización de las conductas empresariales irregulares, que no sólo resultaría ilegítima sino también disfuncional"; EL MISMO, "La protección...", p. 137, donde sostiene que la protección penal del consumidor de servicios financieros estaría justificada en atención a la "dimensión cuantitativa de las magnitudes económicas afectadas en cada caso, como en la multiplicación de los efectos lesivos sobre multitud de innominados afectados. Por no aludir a la afectación de estos delitos a ese marco complejo y heterogéneo que denominamos (...) orden socioeconómico".

${ }^{57}$ Como ya destacara BAJO FERNÁNDEZ, "La delincuencia económica. Un enfoque criminológico y político criminal", CPC (5) 1978, p. 21, es cierto que, en ocasiones y de forma interesada, se apela al argumento del "miedo" consistente en que una excesiva persecución de la delincuencia de cuello blanco, en general, fracturaría el sistema socioeconómico o que el procesamiento de un significado empresario traería consigo, en particular, la ruina de la factoría y con ello la pérdida de numerosos puestos de trabajo. ${ }^{58}$ Como ha puesto de relieve, entre otros, PULIDO BEGINES, RDBB (130) 2013, p. 9, junto a la creciente complejidad del propio producto y la asimetría de información especialmente acusada en este sector, la tercera razón que justificaría la protección del cliente de entidades financieras es la "enorme desproporción de poder negocial que, por lo general, existe entre ambas partes". Desproporción que -añadiría yo-se erige en caldo de cultivo para que se abuse en términos patrimoniales del inversor-consumidor en tanto parte débil de la relación contractual establecida con la entidad bancaria o la sociedad de inversión colectiva de turno. ${ }^{59}$ En esta línea se situaría, RUIZ RODRÍGUEZ, "Limitaciones técnicas, jurídicas e ideológicas para el conocimiento y sanción de la criminalidad económica", RDPC (1) 2009, pp. 382-383, quien ha puesto de relieve cómo la protección de bienes jurídicos-penales supraindividuales en la mayoría de los delitos 
delictivo de todas aquellos mecanismos que, en el plano teórico y práctico, dificultan sobremanera su interpretación y aplicación. Concretamente, me estoy refiriendo a la introducción de elementos de aptitud (p.e., delito de publicidad engañosa, art. $282 \mathrm{CP}$, "de modo que puedan causar un perjuicio grave y manifiesto a los consumidores"); la inclusión de elementos subjetivos adicionales al dolo (p.e., la estafa de inversores, art. 282 bis, "con el propósito de captar inversores o depositantes...."), al margen de error a otorgar en un ámbito eminentemente especializado como el de los negocios ${ }^{60} \mathrm{o}$ la recurrente mención a las condiciones objetivas de procedibilidad (como la prevista, entre otros, en los delitos societarios, art. $296 \mathrm{CP})^{61}$.

6. Esta receta, claro está, debe aderezarse con una correcta selección cuantitativa (marcos penales abstractos) y cualitativa de la pena (tipología) que garantice una correcta acomodación a la gravedad del hecho cometido (delito económico) y a las circuns-

socioeconómicos exige del legislador un plus de precisión en la descripción del injusto objetivo y subjetivo. Además, continúa el citado autor, su configuración como delitos de peligro tampoco coadyuva a garantizar su aplicación dadas las dificultades que la acreditación de este elemento típico plantea en el proceso. Eso sí, llama la atención sobre las facilidades con las que, contrariamente, se entiende probada la lesión del bien jurídico en el marco de los delitos de tráfico de drogas. De lo cual deduce, no sin razón, que los obstáculos no guardan relación con consideraciones estrictamente dogmáticas sino más bien "valorativas".

${ }^{60}$ Esta cuestión deviene esencial desde el momento que, generalmente, en la delincuencia económica no se incrimina la modalidad imprudente y, por tanto, una generosa interpretación del error en que, presuntamente, hubiere incurrido el autor podría traducirse en la impunidad del comportamiento. Claro está, la clave radica aquí en determinar el grado de vencibilidad exigido para otorgarle relevancia jurídico-penal a unos comportamientos enmarcados en ámbitos especialmente complejos, pero, donde quienes interactúan deben contar, simultáneamente, con un grado de conocimiento superior al poseído por el manido "hombre medio". Nos situamos de lleno en la eterna -y crucial- discusión del error (de tipo o de prohibición, según los casos) sobre los elementos normativos del tipo y, consiguientemente, la tortuosa remisión a las profusas y no siempre sistemáticas reglamentaciones mercantiles-tributarias resultado de su configuración como normas penales en blanco. Sobre la particular incidencia del error en los delitos económicos, quisiera traer a colación las reflexiones de RUIZ RODRÍGUEZ, RDPC (1) 2009, pp. 385 y 389, cuando, respectivamente, apunta "El automatismo en la conversión de los errores de tipo en imprudencias y la ausencia de castigo de éstas en la delincuencia socioeconómica presentan un nuevo motivo de ineficacia del sistema penal que, en este terreno, requerirá en el futuro una reflexión en mayor profundidad" y "El recurso al error de tipo o de prohibición, según sea el supuesto, se convierte en instrumento omnipresente en la defensa de los sujetos imputados y en la base de numerosas absoluciones ante los tribunales". Con respecto a esta problemática en general entiendo imprescindibles los trabajos elaborados por DÍAZ Y GARCÍA CONLLEDO, entre los que destacaría, su monografía, El error sobre elementos normativos del tipo penal, Ed. La Ley, Madrid, 2008. ${ }^{61}$ En este punto señala RUIZ RODRÍGUEZ, RDPC (1) 2009, p. 383-385, como "la utilización frecuente de cuantías económicas para dar inicio a la intervención penal o la fuerte tendencia a incorporar elementos patrimoniales en los tipos o cláusulas generales de procedibilidad, han terminado por malograr la vida jurídica de algunos delitos económicos (...) - y con respecto a los elementos subjetivos del injusto concluyeLa finalidad de esta técnica legislativa ha sido claramente recortar el espacio de lo punible para llevar al terreno penal sólo aquellas conductas que en ningún caso pueden ser identificadas como propias y naturales en mercados muy competitivos donde la buena voluntad en los negocios no es un valor preponderante". 
tancias personales del autor (delincuente económico). Y, por supuesto, con un cambio de actitud del legislador y de los principales operadores que conforman el sistema de Justicia penal. A mi juicio, desde siempre, se ha puesto un especial celo en el castigo de los -más- marginados en garantía de una mejor protección de los clásicos intereses $^{62}$. Sin embargo, no se ha dedicado un similar esfuerzo en la persecución y castigo de los graves hechos protagonizados por unos pocos que comprometen seriamente los intereses socioeconómicos de otros muchos (p.e, los consumidores-inversores $)^{63}$. Es

${ }^{62}$ Especialmente ilustrativa resulta la política criminal en materia de delincuencia patrimonial de baja intensidad. Esto es, el hurto y su -insoportable-comparación con la implementada en el ámbito "De los delitos contra la Hacienda Pública y la Seguridad Social”' (arts. 305-310 bis CP). En este punto, quisiera traer a colación las atinadas reflexiones de FERNÁNDEZ TERUELO, Instituciones..., pp. 51-54, quien califica de inexplicable el desigual y favorable tratamiento penológico dispensado a sendos grupos delictivos. No le falta razón cuando enfatiza la activación del delito de hurto en sustracciones superiores a 400 euros frente a los 120.000 exigidos en el delito fiscal o los 50.000 establecidos como límite en el marco del fraude de subvenciones o de la Seguridad Social. Al tiempo que se constata, no sin cierto estupor, como esta enorme desproporción no tiene una respuesta a los efectos de la "cantidad de pena" a imponer. Ciertamente, mientras el hurto, en su tipo básico, tiene prevista prisión de 6 a 18 meses (a castigar, según reza en la LO 1/2015, en su mitad superior de neutralizarse, eliminarse o inutilizarse los dispositivos de seguridad instalados en la cosa sustraída, art. 234.3) y de 1 a 3 años (en los 5 subtipos agravados que en la reforma operada en la LO 1/2015, se han ampliado a 9), el segundo bloque de delitos enumerados una pena acumulativa de 1 a 5 años de prisión y multa. Claro está podrá contraargumentarse que estos últimos cuentan con un marco penal abstracto más amplio y que formalmente se sancionan más duramente. Pero también lo es que -de haberse abierto la fase del Juicio Oral-normalmente no se condena a penas superiores a dos años a quienes son acusados de fraude fiscal, de subvenciones o contra la Seguridad Social. Además el contraste es más llamativo si cabe cuando en el plano estructural se constata, por un lado, el establecimiento de cláusulas de regularización -flexiblemente interpretadas por la jurisprudencia-en unos delitos de naturaleza defraudatoria (arts. 305.4, 307.3 y 308.4). Y, por el otro, comprobamos la rígida aplicación judicial de la teoría de la disponibilidad potencial en un delito patrimonial de apoderamiento -no violento- como el hurto. Lo cual, a juicio del mencionado autor, se traduce en una devaluación del patrimonio público contrario a "los criterios político-criminales en materia de protección específica de la función y sector públicos" (p. 53) que se compadece mal -añadiría yo- con la (sobre)protección que se le dispensa a la propiedad privada. En parecidos términos, se han pronunciado REBOLLO VARGAS / CASAS HERVILLA, "Reflexiones, problemas y propuestas para la investigación de la delincuencia económica”, RGDP (19) 2013, pp. 27-28, quienes, además del ejemplo del hurto, ponen el acento en el desequilibrio penológico reinante entre los delitos de estafa y el fraude fiscal (art. 305) y/o el delito societario de administración desleal, donde junto a la prisión establecida (de seis meses a cuatro años) alternativamente se ha contemplado una mera pena de multa proporcional (triple del beneficio obtenido). Ejemplos todos ellos con los que los citados autores llaman la atención acerca de la "tolerancia o 'benevolencia punitiva' en el ámbito de la delincuencia económica". ${ }^{63}$ En este sentido, comparto la demoledora crítica formulada por DONINI en forma de preocupación, “¿Una nueva Edad Media penal? Lo viejo y lo nuevo en la expansión del Derecho penal económico”, (Méndez Rodríguez, Trad.), en Temas de Derecho Penal Económico, TERRADILLOS BASOCO / ACALE SÁNCHEZ (coords.), Ed. Trotta, Madrid, 2004, pp. 213-214, cuando subraya la coexistencia de sendos tipos de autores en términos criminológicos y dos clases de Derecho penal y de penalistas que lo estudian "(...) Existe, en efecto, un derecho penal de la estigmatización primaria que se acerca, de hecho a un derecho penal del enemigo y que en Italia se prefiere llamar 'de la emergencia' (....) personas de fuera de la Unión Europea, drogodependientes, reincidentes y marginales porque no se seleccionan a través del Tatbestand, 
innegable que el Derecho penal económico ha sufrido una expansión -más nominal que real- en los últimos tiempos y tensionado, en algunos casos, excesivamente los principios limitadores del ius puniendi. Pero también lo es que ello no se ha traducido en un significativo número de condenas y motivado el correspondiente ingreso en prisión. Lo cual habría contribuido a extender la alargada sombra del "Derecho penal simbólico" en sentido negativo ${ }^{64}$.

7. Es posible que como sucede en otras ocasiones, la sociedad vaya por delante del Derecho -en este caso penal- harta como está de los numerosos escándalos que han manchado a "respetables hombres de negocios" que, al amparo de algunos políticos y gestores públicos, obtuvieron ilícitamente ingentes cantidades de dinero. Unas conductas que han generado en la población un grado de indignación mayor debido, en gran parte, a la larga y profunda crisis por la que - pese a lo que digan algunostodavía atravesamos. Lejos han quedado los tiempos en que la ciudadanía admiraba -e incluso homenajeaba- a quienes triunfaban en el mundo de las finanzas, una vez

sino a través de la selección real y natural de la vida. Para este tipo de autores no escribimos demasiadas monografias o análisis, no nos interrogamos sobre las bases empíricas de la prevención general o sobre las alternativas al Derecho penal. Basta aplicar los delitos naturales de siempre (....) Junto a este derecho penal tan tradicional, nos encontramos también el derecho penal de la prevención probada, en el que el jurista se convierte en un técnico excepcional (....) un tecnócrata atento a salvaguardar, caso por caso, los tipos de autor o las víctimas de complicadas figuras penales que se refieren a la vida económica de autores criminológicamente más 'normales' (....) Se estudian nuevos bienes, nuevas vías de intervención, nuevas clases de elementos subjetivos o de sanciones, renovando aquí (pero sólo aquí) la 'cara humana de la justicia penal', y la 'vocación constructiva' de la ciencia".

${ }^{64}$ En la misma línea, se ha expresado TERRADILLOS BASOCO, "Cuatro décadas de política criminal en materia socioeconómica", en Crisis financiera y Derecho Penal Económico, DEMETRIO CRESPO / MAROTO CALATAYUD (coords.), Eds. Edisofer/Bdef, Madrid-Montevideo, 2014, p. 69, cuando concluye "Si la respuesta penal real frente a la delincuencia económica de cuello blanco no puede ser calificada de incisiva, tampoco se puede relativizar la trascendencia de las manifestaciones normativas expansivas que son innegables, aunque a menudo sólo simbólicas, en ciertas parcelas del Derecho penal económico". Es más, apunta -con razón-FERNÁNDEZ TERUELO, Instituciones..., p. 54, que no siendo significativa la expansión del Derecho penal en el ámbito económico, lo que sí se observa, todavía hoy, es "un tratamiento legal especialmente benévolo con quienes desarrollan conductas antisociales en espacios económicos, con la consecuente vulneración del principio de igualdad y la falta de proporcionalidad de la respuesta penal con relación al hecho cometido". En parecidos términos también se ha expresado RUIZ RODRÍGUEZ, RDPC (1) 2009, p. 354, para quien se trata de una expansión más nominal que material como así lo demostraría el hecho de que, barajándose un concepto amplio de delito económico, las cifras oficiales sobre esta criminalidad no superen el 5\% de la delincuencia total. Dicho autor destaca igualmente que la prisión constituye una excepción en el castigo de estas infracciones penales, lo cual daría cuenta de la "percepción del sistema penal sobre esta clase de autores y sobre los hechos que realizan" (p. 370). En la misma dirección se ha pronunciado, últimamente, BAUCELLS LLADÓS, CPC (106) 2012, p. 156, nota 38 , quien si bien admite dicha expansión, también sostiene que no se ha acompañado de una necesaria armonización con los correspondientes ilícitos extra-penales y advierte sobre los riesgos que la utilización simbólica del Derecho penal comporta. 
ha comprobado en primera persona las perniciosas consecuencias económicas derivadas de conductas tales como: a) el falseamiento de la información societaria (caso Gowex); b) la manipulación de la realidad económico-financiera de la sociedad antes de una importante salida a bolsa (caso Bankia); o c) la captación de un buen puñado de pequeños inversores que, seducidos por el eco de importantes campañas publicitarias y la aparente reputación social de su patrocinador, adquirieron pagarés de un potente grupo empresarial que, finalmente, no se hicieron efectivos (caso "nueva Rumasa").

8. Ciertamente, la eficacia probada en la persecución penal de los reos habituales es inversamente proporcional a la -cierta y en sentido decreciente-desidia y desinterés mostrados en el esclarecimiento de hechos en que están implicados reputados miembros de la comunidad económico-financiera ${ }^{65}$. Mientras se continúan todavía focalizando los esfuerzos en la delincuencia de poca monta, los comportamientos que merman la confianza de los ciudadanos en las instituciones e, incluso, en los casos más graves ponen en jaque el equilibrio socioeconómico de un país, orillan, en ocasiones, el Derecho penal ${ }^{66}$. Por su parte, superados los distintos obstáculos que dificultan su efectiva

${ }^{65}$ Si bien es cierto que, según informaciones periodísticas, actualmente más de un centenar de "banqueros" están imputados en sendos procedimientos penales, está por ver cuántos de ellos serán finalmente condenados a penas privativas de libertad de efectivo cumplimiento. Dicho esto, también podría suceder algo parecido a lo acontecido en la persecución penal de la llamada "corrupción político-urbanística", en que después de una primera y desalentadora etapa en que las causas se eternizaban y terminaban en casi nada, de un tiempo a esta parte, han llevado al banquillo a "ilustres" personalidades políticas que han entrado en prisión después de no haber sido merecedoras del indulto solicitado. Tal es el caso del ex presidente balear que ingresó el 28/07/2014 para cumplir una pena de 9 meses de prisión por la comisión de un delito de tráfico de influencias (en una de las 20 piezas separadas del denominado "Caso Palma Arena"). Un camino que igualmente han tomado el ex alcalde de Torrevieja y, el hasta no hace demasiado, intocable ex presidente de la Diputación de Castellón una vez confirmada por el TS la pena de cuatro años de prisión (STS 2307-2014, Pte. Varela Castro) impuesta por la Audiencia Provincial a finales de 2013 al declararlo culpable de otros tantos delitos fiscales. Ejemplos todos ellos de la nueva política de "gracia 0" con respecto a los servidores públicos condenados por "corrupción”. Un ingreso en prisión que, dicho sea de paso, ha eludido el ex presidente -cuasi vitalicio- de la Diputación Provincial de Ourense, quien también ha sido declarado autor de un delito continuado de prevaricación y condenado a una pena de 9 años de inhabilitación especial. A diferencia de los anteriores casos, no será necesaria la petición de indulto porque dejó la vida política dos años atrás y, además, este delito, "sorprendentemente", no permite la imposición de pena de prisión ni tan siquiera una triste multa (art. $404 \mathrm{CP}$ ).

${ }^{66}$ Hago mías las palabras del maestro alemán SCHÜNEMANN, "La denominada...", p. 44, quien ha sintetizado magistralmente esta idea: "El moderno Derecho penal estatal ha surgido como instrumento coactivo contra aventureros y miserables que se encuentran al margen de la sociedad, y a pesar de la teoría del daño social desarrollada por Beccaria (....) y de su desarrollo posterior en la teoría de la protección de bienes jurídicos y en la creación de un especifico Derecho penal económico y del medio ambiente apoyada en la misma, hasta hoy no ha sido capaz de liberarse de esos orígenes y fracasa completamente en la evitación de aquellos daños sociales cuantitativamente mucho mayores, frente a los cuales la sociedad cierra los ojos y deja que sean causados por su propio Establishment. La relación, verdaderamente anormal, entre 
persecución, con demasiada frecuencia, concluyen con el sobreseimiento de la causa después de una larga y trabada investigación judicial ${ }^{67}$.

9. De hecho, en los últimos tiempos diversos autores han prestado atención a esta relevante cuestión (Fernández Teruelo, Corcoy Bidasolo, Baucells lladós, Ruiz Rodríguez, Rebollo Vargas / Casas Hervilla) ${ }^{68}$. Así, el primero de los $\operatorname{citados}^{69}$, después de enumerar los distintos factores que dificultan la detección ${ }^{70}$ y acreditación del delito económico, se centra en aquellos otros que inciden en su efectiva persecución ${ }^{71}$ :

la diaria destrucción del medio ambiente y las bagatelas a las que hace frente el Derecho penal es de todos conocida. Como uno puede ver, no ocurre otra cosa en el Derecho penal económico y financiero, donde adicionalmente la política se esfuerza a fondo, con el vivo apoyo de los medios de comunicación, por disfrazar daños gigantescos, casi quisiera decir que galácticos, tras eufemismos, y por que los causantes del daño no asuman la responsabilidad, sino que sea la generalidad la que responda de ellos...". Un planteamiento que ya asumió en su momento BAJO FERNÁNDEZ, CPC (5) 1978, p. 21, quien, muy gráficamente, concluyó "Legislador, juez y policía son tres mecanismos sociales que practican una decisiva selección en perjuicio del delincuente tradicional y en beneficio de la delincuencia reclutada en las altas capas sociales" y al que se han adherido, más recientemente, entre otros, ZÚÑIGA RODRÍGUEZ, "Culpables, millonarios e impunes: el difícil tratamiento del derecho penal del delito de cuello blanco", en Poder y delito: escándalos financieros y politicos, ZÚÑIGA / GORJÓN / FERNÁNDEZ / DÍAZ (coords.), Ed. Ratio Legis, Salamanca, 2012, p. 40, quien utiliza la ilustrativa expresión "doble vara de medir esas dos clases de criminalidad".

${ }^{67}$ En opinión de REBOLLO VARGAS / CASAS HERVILLA, RGDP (19) 2013, pp. 4 y ss., la abusiva y/o perversa utilización de los recursos han convertido, en particular, a la instrucción en la "instancia infinita" y contribuido, en general, a colapsar la Administración de Justicia. De ahí que propongan como alternativa limitar este derecho y circunscribir la impugnación a los autos en que se decreta la imposición de medidas cautelares o el fin de la instrucción. Fundamentalmente, continúan los citados autores, al Auto de acomodación al Procedimiento Abreviado por ser el momento idóneo para solicitar la práctica de nuevas diligencias y valorar la concurrencia o no de suficientes indicios de criminalidad, garantizando así la continuación del proceso. Se trata de una cuestión francamente compleja. Es cierto que la concatenación de recursos en la fase instructora dilata en exceso la causa, pero también lo es que un recorte severo de la facultad impugnatoria podría menoscabar el derecho de defensa de todo imputado. Estamos ante una manifestación más del eterno dilema representado por el binomio eficacia del sistema de justicia penal versus garantías del justiciable.

${ }^{68}$ De la que ya se ocupara BAJO FERNÁNDEZ a finales de los 70 y cuyas ideas, en gran parte, son plenamente aplicables a la realidad actual pese a los -casi- cuatro décadas transcurridas desde entonces, CPC (5) 1978, pp. 18 y ss.

${ }^{69} \mathrm{Vid}$., FERNÁNDEZ TERUELO, Instituciones..., pp. 68-73.

${ }^{70}$ De hecho, como señalaré más adelante, es justo en la detección de esta criminalidad donde un mayor rendimiento puede extraerse a las "teorías de la oportunidad" como forma de explicación del delito y de aquellos medios cuya implementación podrían coadyuvar a combatirla más eficazmente. O más concretamente, el mejor conocimiento de los elementos que, en mayor o menor medida, contribuyen a desinhibir al delincuente económico podrían ayudar al legislador a adoptar las medidas más idóneas en su desactivación y con ello la evitación futura de unos delitos que, insisto, se caracterizan por su elevada dañosidad social. ${ }^{71}$ En esta línea también se han pronunciado, entre otros, RUIZ RODRÍGUEZ, RDPC (1) 2009, p. 376, quien ha denunciado el grave déficit aplicativo propio de los delitos socioeconómicos (pp. 380-381) y agrupado en tres bloques las cuestiones dogmáticas que dificultan su efectiva implementación en la práctica 
a) el acceso a un amplio conjunto de recursos técnico-jurídicos de defensa que activan mecanismos de dilación en todas las fases del proceso penal; b) el control directo o indirecto de importantes medios de comunicación; c) la capacidad de influencia real sobre el poder político ${ }^{72}$; d) el bloqueo de la acción popular mediante la conocida como "doctrina Botín"; e) la generosa gestión de la prescripción y el indulto y f) el uso y abuso de los paraísos fiscales en tanto factor de carácter mixto que dificulta la detección y la persecución "gracias" a la opacidad y ausencia de colaboración de las autoridades administrativas y judiciales de los países donde se ubican ${ }^{73}$.

forense: a) la determinación de la autoría y la participación de personas físicas y jurídicas; b) la concreción del bien jurídico-penal protegido y c) la propia configuración típica de los comportamientos tanto en su vertiente objetiva como subjetiva. Más recientemente, BAUCELLS LLADÓS, CPC (106) 2012, p. 170, sostiene que la elevada cifra negra que parece registrar la delincuencia económica vendría motivada por las mayores dificultades en la detección de estas infracciones penales. Entre las distintas causas, ya apuntadas en la discusión planteadas en los 80, a juicio del citado autor, siguen vigentes por lo menos en España, las siguientes: a) el acceso a mejores medios de defensa técnica; b) las precarias infraestructuras administrativojudiciales y la ausencia de especialización de Jueces y Magistrados; c) la acreditación de indicios racionales de criminalidad dada la proximidad entre el delito y el análogo ilícito extra-penal; d) el trato más benévolo que, a diferencia del delincuente clásico, le dispensa la policía y otros funcionarios concernidos en la persecución del delito; y e) la confianza de las víctimas en la resolución extra penal del problema y menores incentivos a denunciar los hechos y colaborar activamente con la Justicia. También CORCOY BIDASOLO, "Algunas cuestiones político-criminales sobre la corrupción privada. Límites y eficacia del compliance", en Responsabilidad de la Empresa y Compliance. Programas de prevención, detección y reacción penal, MIR / CORCOY / GÓMEZ (dirs.), HORTAL / VALIENTE (coords.), Eds. Edisofer/Bdef, Madrid-Montevideo, 2014, pp. 165-166 y 171-173, ha enfatizado que la eficacia en la investigación y persecución de los delitos socioeconómicos y de corrupción pasa, necesariamente, por la mejora de los siguientes aspectos: a) una adecuada dotación de medios humanos y materiales (peritos económicos independientes y rápido acceso a la información); b) la independencia de los órganos encargados de la persecución penal, concretamente, de los fiscales; y c) garantizar el flujo de información entre los países dada la "internacionalización" propia de los delitos económicos y erradicar los paraísos fiscales que siendo una utopía-continúa la autora- "sería la única posibilidad real de acabar, o limitar en gran medida, la delincuencia socioeconómica y patrimonial, en gran escala, así como los incentivos para la corrupción" (pp. 172-173).

${ }^{72}$ A estos tres factores apelaba BAJO FERNÁNDEZ, CPC (5) 1978, p. 22, cuando señaló la necesidad de no olvidar que "el ilícito económico está fuertemente financiado, siéndole fácil conseguir toda clase de ayuda. Y que el delincuente es riguroso en su propia defensa movilizando todo su poder, prestigio e influencia -y apostilla- Precisamente, se dice, que el gansterismo americano fue posible por el apoyo de juristas de todos los estamentos".

${ }^{73}$ En la misma línea, se sitúan REBOLLO VARGAS / CASAS HERVILLA, RGDP (19) 2013, pp. 4 y ss., quienes sistematizan las causas que entorpecen la -rápida y eficaz-investigación de la delincuencia socioeconómica en torno a dos grandes grupos: las procesales y las que denominan "cierta tolerancia-operada-en los planos legislativo, judicial, e incluso social". Centrándome en las primeras, distinguen, por un lado, las dilaciones en la tramitación del proceso motivadas por una deficiente aplicación de la conexidad procesal; la "beligerancia impugnatoria" y, pese a los avances, un sistema todavía demasiado arcaico de notificaciones, citaciones y emplazamientos. Y, por el otro, los calificados "obstáculos orgánicos" tales como la ausencia de especialización en la judicatura que sí ha tenido lugar -aunque se precisen de más medios humanos y materiales- en la fiscalía; la propia incoación del procedimiento que, en gran medida, queda en manos de la fiscalía y la persona agraviada dada la naturaleza semipública de estos delitos y la complejidad probatoria 
10. Unas causas cuya dilatación espacio-temporal, en la práctica, se traducen o pueden traducirse en una reducción de la pena impuesta al acusado efectivamente enjuiciado de aplicarse la atenuante de dilaciones indebidas. O, en su caso, incluso, en la elusión del ingreso en prisión de estimarse como muy cualificada ${ }^{74}$. Claro está, si el Juez o Tribunal sentenciador concede la suspensión condicional que, de momento, tiene un carácter potestativo y no obligatorio en nuestro ordenamiento penal ${ }^{75}$. Insisto en ello porque este mecanismo alternativo a la prisión, ha experimentado en los últimos tiempos una suerte de transformación pasando la jurisprudencia de su concesión (cuasi) automatizada a su discutible negación en algún caso de notable relevancia mediáticosocial $^{76}$. Por supuesto, de no vadear la prisión por esta vía, el condenado siempre podrá

consustancial a estas causas. Dificultades estas que, a su juicio, "sólo” pueden contrarrestarse parcialmente mediante la adscripción de peritos especialistas en contabilidad, fiscalidad, Tic's, etc., tanto a los Juzgados de Instrucción como a la fiscalía de delitos económicos. En este punto, ya denunció BAJO FERNÁNDEZ, CPC (5) 1978, pp. 22-23, que existían dos obstáculos cruciales en la persecución judicial de la delincuencia económica. Por un lado, la falta de personal especializado que auxilie al Juez en el esclarecimiento penal de los hechos y su posterior enjuiciamiento. Y por el otro, el muro infranqueable del "secreto bancario suizo" en tanto "dificultad procesal última".

${ }^{74}$ En este punto concluyen REBOLLO VARGAS / CASAS HERVILLA, RGDP (19) 2013, p. 25, como la combinación de un sistema de agravantes y atenuantes más benévolo y beneficioso para el delincuente económico y el actual régimen de suspensión y sustitución de las penas privativas de libertad, traería consigo "que ante la predecible imposición de penas inferiores a dos años de prisión (...) sólo en un infimo número de casos el delincuente económico llegue a cumplir de modo efectivo la pena impuesta toda vez que se tratará de un sujeto 'no necesitado' de rehabilitación o reeducación, por lo que desde una perspectiva preventivo especial el cumplimiento de la pena no se hallaría justificado".

${ }^{75}$ Un rasgo que, pese a las notables modificaciones operadas en el régimen jurídico de la suspensión por mor de la LO 1/2015, se ha mantenido en la reforma que -vía exprés- entró en vigor el 1 de julio. Para un detallado análisis del Anteproyecto -julio de 2012-; el proyecto y el texto finalmente aprobado pueden consultarse, entre otros, los trabajos de TRAPERO BARREALES, "El nuevo modelo de suspensión de la ejecución de las penas privativas de libertad en el anteproyecto de reforma del CP”, DLL (7941) 2012, 33 pp.; RoIG Torres, "La suspensión de la pena en el proyecto de reforma del Código Penal. Un giro hacia el Derecho penal de autor", RP (33) 2014, pp. 170-207; LA MISMA, "Suspensión de la ejecución de las penas privativas de libertad (arts. 80, 81 y 82)", en Comentarios a la reforma del Código Penal de 2015, GONZÁLEZ CUSSAC (dir.), Ed. Tirant, Valencia, 2015, pp. 323-339.

${ }^{76}$ No fue el caso de los Mossos D'Esquadra que fueron condenados, tres de los cuatro, por la Audiencia Provincial de Barcelona a penas de 6 años y 7 meses de prisión por la comisión de sendos delitos de torturas (art. 174); lesiones (art. 147) y contra la inviolabilidad domiciliaria (art. 534.2 ${ }^{\circ}$ ) al confundir a la víctima -un ciudadano rumano- como el presunto autor de un delito de robo con violencia e intimidación. Tras reducirla el Tribunal Supremo en un año y 10 meses, el Ejecutivo central concedió el indulto parcial dejando la pena de prisión en dos años en la creencia de que el Tribunal sentenciador, siguiendo esta cuestionable praxis judicial, concedería la suspensión condicional y con ello se evitaría el efectivo ingreso en prisión. Sin embargo, la sección 9a, se negó a “cumplir" el plan trazado, y desestimó una vez más la petición de suspensión solicitada por los agentes condenados, reproduciendo en los cuatro autos dictados idénticos argumentos (AAP Barcelona, ejecutoria 11/2010, de 28-06-2012, FD 2 ${ }^{\circ}$ ): a) "el carácter excepcional de la decisión potestativa y discrecional solicitada, de concesión no automática ni obligatoria"; b) "la naturaleza y especial gravedad de los hechos"; c) "la existencia de elementos indicativos de especial peligrosidad 
solicitar el correspondiente indulto al Gobierno y resultar agraciado con este vestigio del pasado que, además de una burla a la Administración de Justicia, constituye una flagrante conculcación de la división de poderes.

\section{A buen seguro el más sonado y vergonzante de todos ellos, fue el concedido -en contra del sentir del TS- a finales de 2011 a Alfredo Sáenz a la sazón Consejero De- legado del Banco de Santander, en que se conmutó la pena impuesta de arresto mayor y la accesoria de suspensión de ejercicio profesional por una multa de 6.000 euros. El mencionado "banquero" había sido condenado como autor de un delito de acusación y}

criminal del condenado"; y d) "la condición del penado y el hecho de que el condenado ejecutara dicha actuación delictiva en la condición de agente de policia". Ante dichas resoluciones, los agentes solicitaron un nuevo indulto que, sorprendentemente, el Gobierno concedió, conmutando así la prisión ya reducida en una pena de multa de 7.200 euros. Un reindulto que, además de despertar numerosas críticas en la opinión pública, llevó a 200 magistrados a firmar un documento titulado "Contra el indulto como fraude en defensa de la independencia judicial y de la dignidad" en que calificaron la decisión gubernamental de "impropia de un sistema democrático de Derecho, ilegítima y éticamente inasumible". Sobre este caso, se han pronunciado, entre otros, REBOLLO VARGAS/CASAS HERVILLA, RGDP (19) 2013, p. 27, quienes denuncian la "poca receptividad" del Ejecutivo cuando se rechaza el indulto en casos de "delincuencia tradicional" (p.e., el de David Reboredo) al tiempo que se "adoptan decisiones grotescas como es el caso de los miembros de los Mossos d'Esquadra condenados por un delito de torturas e indultados dos veces por el Gobierno para evitar su ingreso en prisión". Ahora bien, si injusto resulta este automático proceder judicial, también lo es, a mi juicio, la situación inversa implementada últimamente en causas de especial interés informativo-amarillista. La denegación, por definición, de la suspensión condicional de la pena habiéndose acreditado la simultánea ausencia de peligrosidad criminal del reo y, consiguientemente, la inexistencia de un riesgo -cierto- de reiteración delictiva. De ahí que pueda cuestionarse, entre otras, la decisión adoptada por la Audiencia Provincial de Málaga (sec. $2^{\mathrm{a}}$, ejecutoria 50/14, 3-11-2013) en el caso de una conocida tonadillera condenada a 2 años de prisión por la comisión de un delito de blanqueo de capitales a resultas de la mediática relación mantenida con el polémico alcalde de una, no menos afamada, villa malagueña (SAP Málaga, Secc. 2a $2^{\mathrm{a}}$ 179/13, Pte. Soriano Parrado). Como decía albergo serias dudas porque parece desprenderse de su argumentación que la inadmisión se sustenta -no como debería- en el pronóstico de peligrosidad criminal del peticionario, sino en la gravedad objetiva de los hechos cometidos - que en modo alguno quiero devaluar-, y, especialmente, en la relevancia social de quienes los cometieron y la consiguiente "alarma" que los mismos generaron en la opinión pública y publicada. No en vano, el mencionado Tribunal concluyó "En consecuencia, la Sala entiende que, si bien no existe esa peligrosidad subjetiva que deriva de que ninguno de los dos penados está en fácil disposición de cometer otros delitos como el que fue objeto de condena, blanqueo de capitales, por las razones ya apuntadas; sin embargo, sí que existe una peligrosidad objetiva e intrínseca en los condenados que deriva de los factores también ya dichos, es decir: la entidad de los hechos por los que fueron condenados, sus circunstancias personales y su conducta ulterior y actual de no asunción del delito". En torno a la conducta "ulterior y actual" considero, hasta cierto punto lógico, que quien ha negado, en todo momento, su participación en los hechos por los que finalmente fue condenada, mantenga su inocencia tras el fallo-confirmado por el TS- y también durante la fase de ejecución de la pena, toda vez que el rechazo de este sustitutivo penal, determinaba -como así fue- el cumplimiento efectivo de la prisión decretada. En definitiva, no creo que los dos casos examinados merecieran idéntico tratamiento judicial y lo dice alguien muy crítico con la asunción de cualquier automatismo que, per se, resulta contrario a lo que entiendo una correcta y ponderada Administración de la JUSTICIA. 
denuncia falsa con la concurrencia como muy cualificada de la atenuante de dilaciones indebidas (STS 1193/2010, de 24 de febrero). A resultas de esta benigna decisión se eliminaron sus antecedentes penales y con ello el obstáculo para el desempeño de "cargos de dirección, públicos o privados, vinculados a entidades bancarias, crediticias o financieras" (de acuerdo con lo previsto en el RD 1245/1995). Sin embargo, la Sala $3^{\text {a }}$ del TS en la Sentencia dictada en fecha de 12 de febrero de 2013 (Pte. Lesmes Serrano), anuló el inciso final del RD 1761/2011 en que se acordó el indulto y que rezaba como sigue “....y quedando sin efecto cualesquiera otras consecuencias jurídicas o efectos derivados de la sentencia, incluido cualquier impedimento para ejercer la actividad bancaria...". A juicio del Alto Tribunal, el Gobierno se extralimitó en sus facultades de gracia al extender el indulto, circunscrito a la pena, también a los efectos administrativos, proceder este contrario al principio de legalidad ${ }^{77}$.

12. Por último y, a medio camino entre ambos "escenarios", no debemos obviar las consabidas conformidades que se suceden cuando de la imputación de delitos económicos se trata. Una manifestación del principio de oportunidad en el proceso penal que permite al acusado no sólo evitar el estigma del juicio oral, sino, fundamentalmente, la estancia carcelaria de solicitarse penas privativas de libertad ${ }^{78}$. No obstante, la sobreutilización de este instrumento impide a la sociedad conocer en profundidad los pormenores del caso mediante la práctica de todas las pruebas en el plenario. Una victoria pírrica de la Administración de Justicia que genera en buena parte de la ciudadanía la amarga sensación de que la cárcel está reservada para quienes menos tienen.

\footnotetext{
${ }^{77}$ Sobre esta problemática se han pronunciado, entre otros, BAUCELLS LLADÓS, CPC (106) 2012, pp. 153-154, para quien el elevado número de indultos otorgados con ocasión de la comisión de delitos económicos constituye una manifestación más de la "condescendencia legal" hacia esta criminalidad; REBOLLO VARGAS / CASAS HERVILLA, RGDP (19) 2013, pp. 26-27, quienes se muestran especialmente críticos con la tolerancia con la que, en ocasiones y con independencia del partido en el Gobierno, se otorgan los indultos, trayendo, precisamente, a colación el "Caso Sáenz"; TERRADILLOS BASOCO, "Cuatro décadas...", p. 59, quien califica el indulto de "claro mecanismo de inhibición práctica del sistema penal" y de "generoso" el otorgado al banquero en cuestión. Para una breve descripción de este ilustrativo caso puede consultarse la monografía de FERNÁNDEZ TERUELO, Instituciones..., pp. 232-233.

${ }^{78}$ Sirva como ilustrativo ejemplo, la Sentencia dictada por la Audiencia Nacional en fecha 28 de mayo de 2014 (Juzgado Central de lo Penal, $n^{\circ}$ 1), en que previa conformidad y devolución de las millonarias cantidades percibidas en concepto de prejubilación, se condenó a cuatro ex altos directivos de la extinta Caixa del Penedès -que recibió ayudas públicas del FROB por un total de 915 millones de euros-a una pena de dos años de prisión (el ex director general, en concepto de autor) y a una pena privativa de libertad de un año (dos ex directores generales adjuntos y el ex director general que sustituyó al primero, todos ellos responsables en concepto de cooperadores necesarios) por la comisión de un delito continuado de administración desleal. Existe una íntima relación entre las instituciones de la conformidad y la suspensión condicional, por cuanto, en la práctica de activarse la primera, suele, automáticamente, concederse la segunda. Lo cual determina que supuestos de especial gravedad, no sólo orillen el "estigma" de la vista oral, sino también la estancia -aunque fuera corta- carcelaria.
} 


\section{Vademécum punitivo contra la criminalidad de cuello blanco}

\section{a) Aproximación criminológica a los rasgos de la delincuencia socioeconómica}

1. Una vez despejada la "incógnita" del rol a cumplir por el Derecho penal en la gestión de los riesgos sistémico-económicos consustanciales a la crisis, así como los delitos cometidos a su amparo, destinaré las próximas páginas al tratamiento punitivo a dispensar a la delincuencia socioeconómica ${ }^{79}$. Junto a la multa y la inhabilitación profesional, me ocuparé, siquiera brevemente, del papel que cumple o debería cumplir la prisión en la lucha contra esta manifestación criminal. El limitado objeto de la presente investigación sólo me permite realizar una sucinta y parcial aproximación a una problemática en que, lógicamente, resultan imprescindibles las aportaciones de los penalistas, pero también la expertise de los criminólogos. Esta afirmación trae causa de mi creciente convicción acerca de la relevante función desempeñada por la criminología en la construcción y aplicación del Derecho penal.

2. El peso de la criminología es tal que abogo por la figura del "penalista mestizo" que, en el plano académico, identifico con aquél profesional que, además de dominar la política criminal y la dogmática, tiene un conocimiento del sustrato empírico facilitado, precisamente, por la primera de las disciplinas enumeradas. Un sustrato que entiendo esencial para valorar, de lege ferenda, la oportunidad de las -recurrentes- reformas anunciadas y testar, de lege lata, la auténtica eficacia de las ya implementadas. A mi juicio, el penalista debe conocer la prevalencia real del comportamiento sobre el que se pretende legislar (pensemos, por ejemplo, en el fenómeno del online child grooming), así como la incidencia efectiva de la norma penal incorporada en su prevención y sanción (siguiendo con el ejemplo, la introducción en la LO 5/2010 del mal llamado ciberacoso

\footnotetext{
${ }^{79}$ Estamos ante una cuestión capital en la neutralización de una criminalidad cuyas especificidades y complejidad aconsejan una (re)consideración de las viejas fórmulas punitivas pensadas para los clásicos delitos violentos y contra la propiedad. Además se trata de una problemática atemporal porque, de poco o nada, sirven las viejas y las nuevas tipificaciones si no se acompañan de un sistema de penas adecuado -en el sentido de proporcional y eficaz- para prevenir y castigar los comportamientos que están en su base. En esta línea, se han manifestado, entre otros muchos, DE VICENTE MARTÍNEZ, "Sanciones y reparación en el derecho penal económico", en Cuestiones actuales de derecho penal económico, SERANO-PIEDECASAS FERNÁNDEZ / DEMETRIO CRESPO (coords.), Ed. Colex, Madrid, 2008, pp. 187-188, quien se hace eco de las palabras ya pronunciadas por el maestro alemán TIEDEMANN en los 70 y en los 80 -todavía hoy vigentes-acerca de la centralidad en el plano político-criminal de las consecuencias jurídicas en el Derecho penal económico; LANDROVE DÍAZ, JpD (31) 1998, pp. 35-36, quien lo califica de problema "neurálgico" de la delincuencia económica cuya "reduplicada" dañosidad social urge la "búsqueda de los más idóneos mecanismos para combatirla" (p. 35 in fine).
} 
en el art. 183 bis $)^{80}$. De contar con tales conocimientos, gozará de una mejor posición para calibrar si estábamos ante un interés merecedor y necesitado de protección penal. Y de no serlo, cuestionar acto seguido, la decisión tomada en favor de su incriminación. Por su parte, la información acerca de su aplicación práctica, proporcionará al penalista una herramienta muy útil a la hora de formular propuestas de lege ferenda que doten al precepto de una mayor eficacia en la detección, persecución y castigo del comportamiento en cuestión ${ }^{81}$.

3. Efectivamente, el adecuado conocimiento de la realidad empírica deviene esencial, primero, en el cabal y ponderado diseño de la política criminal ${ }^{82} \mathrm{y}$, por ende,

\footnotetext{
${ }^{80}$ Cuestiones de las que me he ocupado en el artículo titulado "El nuevo delito de online child grooming (art. 183 bis CP): ¿otro ejemplo de cirugía preventiva aplicable a la legislación penal", en Garantías constitucionales y Derecho penal europeo, MIR PUIG / CORCOY BIDASOLO (dirs.), GÓMEZ MARTÍN (coord.), Ed. Marcial Pons, Barcelona, 2012, pp. 425-448.

${ }^{81}$ En esta línea se situarían, entre otros, TAMARIT SUMALLA, "Política criminal con bases empíricas en España", PC (3) 2007, quien ha enfatizado la relevancia que el conocimiento de la realidad facilitado por la investigación empírica tiene en la política criminal como "saber cientifico" (p. 2) y, denunciado, entre otros aspectos: a) el modesto desarrollo que la criminología ha tenido en España y el -injusto- tratamiento marginal que se le ha dispensado desde muchos ámbitos académicos y la propia política universitaria ( $\mathrm{p}$. 5); y b) la excesiva concentración de la doctrina penalista en una dogmática alejada de la realidad que, normalmente, no presta atención al análisis empírico fundado (p. 6) y que salvo honrosas excepciones -cita los trabajos del profesor DÍEZ RIPOLLÉS-, tampoco ha desplegado demasiados esfuerzos en la construcción de una teoría sobre la elaboración de las leyes penales (p. 7). Sin lugar a dudas la monografía elaborada por el último de los autores citados, La racionalidad de las leyes penales. Práctica y teoría, Ed. Trotta, Madrid, 2003, marcó un antes y un después en la atención patria a esta fundamental cuestión. De hecho, dos de sus discípulos, se han ocupado de ello en el último lustro, BECERRA MUÑOZ, La toma de decisiones en política criminal, Ed. Tirant, Valencia, 2013 (671 pp.) y CEREZO DOMÍNGUEZ, El protagonismo de las víctimas en la elaboración de las leyes penales, Ed. Tirant, Valencia, 2010 (102 pp.,), quien, a diferencia del tratamiento general e interdisciplinar formulado por el primero, pone el acento en el capital y creciente papel desempeñado por la víctima en la gestación de la legislación penal.

${ }^{82}$ Ciertamente, en el plano teórico, cuando el legislador se plantea la necesidad de reaccionar contra determinados comportamientos que lesionan intereses sociales prevalentes, puede, o mejor dicho, debe decantarse, principalmente, por la adopción de medidas extra-penales. Y, sólo una vez constatada la ineficacia de éstas, habrá de calibrar si, alternativa o cumulativamente, precisa también la intervención del Derecho penal para prevenirlos y, en su caso, sancionarlos. En este sentido, puede concluirse entonces que la Política criminal, en tanto parte de la agenda de los poderes públicos encaminada a combatir el crimen, englobaría tanto la adopción de medidas estrictamente penales como extra-penales. De hecho, entendida la criminología en su acepción extensiva, compartiría parte del objeto propio de la Política Criminal, por cuanto, junto a la explicación de las causas del delito, tiene por finalidad el diseño de los instrumentos o procedimientos -punitivos y no punitivos- cuya implementación permiten prevenirlo más eficazmente. En este sentido, ROSEMARY BARBERET, "La investigación criminológica y la política criminal", RDPC (5) 2000, p. 222, concluye "La política criminal desde un punto de vista criminológico incluye las intervenciones jurídicas y extrajurídicas, públicas y privadas, que tienen como fin prevenir o reducir la delincuencia, o paliar los costes sociales del mismo".
} 
en la elaboración de una legislación penal -más- racional y eficaz ${ }^{83}$. Segundo, en la propia evaluación de la norma penal una vez aplicada -o inaplicada- por los Jueces y Tribunales ${ }^{84}$. Y, tercero, en la praxis judicial, donde los -aún embrionarios- informes criminológicos podrían ser de gran utilidad tanto a las partes como al juzgador en la acreditación de las causas de inimputabilidad (evidente en los casos de drogadicción y toxicomanías de notable incidencia en la práctica forense) o en la adopción de las medidas de seguridad. Y, muy especialmente, en la ejecución de la pena que, entendida en un sentido amplio, englobaría tres grupos de cuestiones a cuál de ellas más importante: a) la determinación de la clase y cantidad de pena a imponer (individualización de la pena stricto sensu); b) la posible activación de las alternativas a la penas privativas de libertad (el binomio suspensión-sustitución); y, claro está, c) la fase propiamente penitenciaria de cumplimiento efectivo de la prisión que, todavía hoy, sigue ocupando un lugar central en los sistemas de penas dentro y fuera de nuestras fronteras (grados, permisos, libertad condicional,... $)^{85}$.

4. Ahora bien, como sucede en otras ocasiones, existe una notable distancia entre el "ser" y el "deber ser". Esto es, entre los escasos conocimientos criminológicos que actualmente atesoran la mayoría de Jueces y de los que dispondrían, en el futuro, de contar en sus respectivas oficinas judiciales con los profesionales que sí los poseen,

\footnotetext{
${ }^{83}$ En este sentido se han expresado, entre otros, RAMÓN RIBAS, "La criminología en la aplicación del Derecho Penal", RDyPP (23) 2010, p. 20, quien acertadamente añade como las decisiones penales adoptadas por el legislador desprovistas de toda base empírica desembocan en "soluciones arbitrarias e ineficaces" que son favorablemente acogidas por la ciudadanía, al contemplarse -erróneamente matizaría yo- como "respuestas rápidas y expeditivas al crimen". El desprecio mostrado por el legislador hacia el saber criminológico en las sucesivas y recurrentes reformas penales perpetradas dan cuenta de su errático e irracional proceder. Al respecto resultan especialmente ilustrativas, las reflexiones realizadas por TiEDEMANN, Lecciones de Derecho penal económico, Ed. PPU, Barcelona, 1993, p. 250, quien ya enfatizó la relevancia de la información criminológica en la elaboración de una concreta política criminal.

${ }^{84}$ Así lo ha puesto de manifiesto, entre otros, RAMON RIBAS, RDyPP (23) 2010, pp. 20 y ss., quien concluye "la Criminología debe evaluar al propio Derecho Penal y, más exactamente, determinar si es eficaz en la lucha contra el crimen o, mejor, si lo son los diferentes delitos y faltas con los que pretende proteger los más importantes bienes jurídicos. Por ejemplo, promulgada una nueva ley, la Criminología puede ayudar a averiguar si ha disminuido la conducta delictiva que desea prevenirse y, en su caso, qué ha fallado en la aplicación de la ley".

${ }^{85}$ En parecidos términos se ha pronunciado, entre otros, RAMON RIBAS, RDyPP (23) 2010, pp. 29-34, quien ha destacado la relevancia que adquieren los aspectos criminológicos en la concreción de dos conceptos altamente indeterminados como las "circunstancias personales del delincuente" y la "peligrosidad criminal" del reo. Elementos ambos que son esenciales tanto en la individualización judicial de la pena y la concesión de los sustitutivos penales (más en la suspensión que en la extinta sustitución) como en la concreción del grado y el otorgamiento de permisos penitenciarios. Para un detallado análisis del criterio "circunstancias personales del delincuente", recomiendo la lectura de la excelente monografía de Besio HeRnÁNDEZ, Los criterios legales y judiciales de individualización de la pena, Ed. Tirant, Valencia, 2011, pp. 405-486.
} 
los criminólogos. Una realidad que se me antoja muy lejana todavía dada la escasa voluntad que se percibe entre quienes podrían decidir la incorporación de este útil -y olvidado-colectivo a las distintas instituciones que interactúan en el sistema de justicia penal: la policía, la fiscalía y la propia Administración Penitenciaria donde, como de todos es sabido, el jurista-criminólogo es, fundamentalmente y (cuasi)exclusivamente, un especialista en Derecho penitenciario.

5. Quisiera iniciar el análisis de los aspectos empíricos, destacando el menor interés mostrado por los criminólogos - con la excepción de los anglosajones y germanos-a la delincuencia económica ${ }^{86}$. Y la (sobre)atención que, contrariamente, se le habría dispensado a la criminalidad de corte violento anclada en el tradicional tridente: [vida/ integridad física]/[robos con fuerza/violencia e intimidación]/[violación/abuso sexual]. Diversas son las causas que, en opinión de algunos autores, explicarían esta -parcialausencia de estudios: a) la inexistencia en el pasado de tipos que sancionaran penalmente una significativa parte de los comportamientos que actualmente se englobarían -en sentido amplio- en el "Derecho penal económico"87; b) las mayores dificultades que la delimitación del ámbito típico plantea en los delitos socioeconómicos ${ }^{88}$, así como la cercanía de las élites más pudientes a los centros de poder que tienen encomendada la acción legislativa; y c) la concurrencia de una especie de presunción de socialización

\footnotetext{
${ }^{86}$ Así lo han señalado, en nuestra doctrina, entre otros, NIETO MARTíN, "Cumplimiento normativo, criminología y responsabilidad penal de personas jurídicas", en Manual de cumplimiento penal en la empresa, NIETO MARTÍN (dir.), Ed. Tirant, Valencia, 2014, p. 50; BAUCELLS LLADÓS, CPC (106) 2012, pp. 144-145; FERNÁNDEZ TERUELO, Instituciones..., p. 76; RUIZ RODRÍGUEZ, RDPC (1) 2009, pp. 350-351, para quien esta escasez de investigaciones criminológicas sobre la criminalidad económica habría redundado "en el desconocimiento de las características y elementos que definen al delincuente económico y sus métodos de actuación" (p. 357); en la doctrina germana, entre otros, ALBRECHT, "Investigaciones sobre criminalidad económica en Europa: conceptos y comprobaciones empíricas", en Modernas tendencias en la ciencia del derecho penal y en la criminología, Ed. Uned, Madrid, 2001, p. 276; y en la doctrina norteamericana, entre otros, BENSON, M.L., "Carreras delictivas de delincuentes de cuello blanco", en Derecho penal y criminología como fundamento de la política criminal, LH-Profesor Alfonso Serrano Gómez, BUENO ARÚS / GUZMÁN DALBORA / SERRANO MAÍLLO (coords.), Ed. Dykinson, Madrid, 2006, p. 152; GEIS, LH-Profesor Alfonso Serrano Gómez, p. 310. Con respecto a la cibercriminalidad económica, "denuncia” MIRÓ LLINARES, El cibercrimen..., p. 245, el escaso número de estudios criminológicos solventes acerca del perfil del ciberdelincuente económico. Lo cual, apunta, no debería extrañarnos y ello por dos motivos: a) en primer lugar, porque se trata de un fenómeno aún demasiado novedoso; y b) en segundo lugar, porque en comparación con la prevalencia de la ciberdelincuencia, el grado de detección de estos delincuentes es todavía muy pequeño, entre otros factores, debido a las mayores dificultades en orden a su identificación y posterior procesamiento.

${ }^{87}$ En esta línea se han pronunciado, entre otros, RUIZ RODRÍGUEZ, RDPC (1) 2009, p. 350, quien concluye "la falta de objeto de estudio centró en el delincuente marginal y en el delincuente enfermo la atención de los estudios sobre el crimen".

${ }^{88}$ Vid., ALBRECHT, “Investigaciones...”, p. 260.
} 
del delincuente económico que no sólo habría desincentivado - en distintos grado de intensidad- la efectiva persecución, enjuiciamiento y condena de esta clase de delitos, sino también, erigido en argumento central de la inidoneidad de la prisión como pena -legítima- para prevenir y sancionar esta delincuencia ${ }^{89}$.

6. Ahora bien, ¿Qué penas se presentan cómo las más adecuadas para combatir la delincuencia de cuello blanco? Una respuesta solvente a esta crucial a la par que difícil pregunta requeriría un exhaustivo estudio monográfico que supera en mucho las pretensiones del presente trabajo. En este caso, el lector tendrá que conformarse con un análisis algo más modesto. Al respecto entiendo oportuno iniciar mi exposición haciendo hincapié en una idea básica. No se puede diseñar, político-criminalmente hablando, un sistema de penas racional, proporcional y eficaz en la prevención y sanción de esta criminalidad sin tomar en consideración dos vectores criminológicos íntimamente conectados: a) dadas las dificultades para construir un perfil-o perfiles-de delincuente económico ${ }^{90}$, entiendo de más utilidad -en términos político-criminales- determinar los rasgos que, comúnmente, confluirían en la criminalidad de corte socioeconómico;

\footnotetext{
${ }^{89}$ Así lo ha puesto de manifiesto RUIZ RODRÍGUEZ, RDPC (1) 2009, pp. 351 y 363, para quien, a diferencia del infractor tradicional, el delincuente económico presenta un grado de socialización, integración y participación en las estructuras económicas y políticas del poder que lo convierten en un destinatario no habitual de la respuesta penal en general y de la prisión en particular.

${ }^{90}$ Siguiendo en este punto a FERNÁNDEZ TERUELO, Instituciones..., p. 77, quizás resulte de utilidad diferenciar en el seno de esta criminalidad dos tipos de delincuentes tomando como criterio rector la dimensión de la empresa u organización en la que operan. Por un lado, el "mayor o de primer grado" identificado con aquellas personas que gestionan un significativo volumen de negocio, cuyos comportamientos son idóneos para lesionar a un elevado número de personas (consumidores, trabajadores, accionistas, inversores...) y que, en definitiva, poseen un componente desestabilizador del sistema socioeconómico. En contraposición, al digamos delincuente económico "menor o de segundo grado" (en el sentido del alcance de las quemaduras y no de las agravaciones penales), como aquél situado al frente de una pyme, un humilde establecimiento comercial o la gestión de una comunidad de vecinos y que, respectivamente, defrauda a la Hacienda Pública, estafa al limitado número de consumidores o clientes con los que interactúa o se acaba apropiando de una pequeña cantidad del dinero que administra. Ilícitos todos ellos que formarían parte del Derecho Penal Económico en un sentido amplio, pero, en términos criminológicos y político-criminales, el legislador debería focalizar sus esfuerzos más en los comportamientos desarrollados por los primeros que en los perpetrados por los segundos porque, junto a la lesión de los intereses patrimoniales individuales, el "delincuente económico mayor" puede, adicionalmente, menoscabar la confianza en el mercado y, por ende, afectar el siempre sensible equilibrio socioeconómico. Un plus que entiendo fundamental en la medida en que las afectaciones del orden socioeconómico, desgraciadamente, suelen traducirse en la puesta en peligro - sino lesión- del Estado del Bienestar y con ello la dilución -siquiera parcial- del vector Social de la fórmula "Estado Social y Democrático de Derecho" constitucionalizada en el art. 1.1 de nuestra Carta Magna. Ciertamente, un Estado menos Social es, en última instancia, un Estado menos justo e igualitario y donde la LIBERTAD con mayúsculas acaba convirtiéndose más en un Derecho formal que real.
} 


\section{y b) simultáneamente ha de incidirse en las causas que, hipotéticamente, moverían al "delincuente económico" a cometer dichas infracciones penales ${ }^{91}$.}

7. Con todas las cautelas, y siguiendo -parcialmente- en este punto a BAUCELLS LLADÓS, varios son los rasgos que caracterizarían a la delincuencia de cuello blanco. En primer lugar, la pertenencia de sus potenciales autores a un círculo social medio-alto, dotado -aunque menos en nuestros días- de un cierto halo de prestigio y reconocimiento en amplios sectores de la sociedad, así como un elevado nivel formativo ${ }^{92}$. Su

\footnotetext{
${ }^{91}$ Cuestiones ambas de las que, recientemente, se ha ocupado BAUCELLS LLADÓS, CPC (106) 2012, pp. 146-155, en la primera parte de un trabajo cuyas conclusiones, como podrá comprobar el lector, comparto en lo esencial.

${ }^{92}$ De hecho, tal y como apunta BAUCELLS LLADÓS, CPC (106) 2012, p.146, ello estaría en el origen de la utilización de la expresión "Respectable Crime" ("delito de la gente respetable") o la mención "delincuencia de la gente honrada" a la que apela LANDROVE DÍAZ, JpD (31) 1998, p. 35. No en vano, el alto nivel social de estos autores fue uno de los pilares sobre los que pivotó la exitosa definición de "delincuencia de cuello blanco" formulada por el sociólogo norteamericano SUTHERLAND. Como ya destacara BAJO FERNÁNDEZ en España a finales de los 70, CPC (5) 1978, p. 6, el origen sociológico constituye una nota esencial de la delincuencia económica porque son precisamente los comportamientos protagonizados por las clases más pudientes los que resultan más dañinos para el conjunto de la ciudadanía. Y no sólo en términos cuantitativos, sino, especialmente, porque son las capas más populares los que sufren en mayor medida sus efectos. Una conclusión plenamente vigente de ojear las secciones económicas y de sucesos de cualquier periódico de tirada nacional donde se hacen eco de los distintos escándalos económicos-financieros que siguen - a pesar de todo-sorprendiendo a la cansada y resignada población que, directa o indirectamente, padece sus consecuencias, entre otras, en forma de recortes en el maltrecho Estado del Bienestar. De ahí que no le falte razón a ORTIZ DE URBINA GIMENO, cuando defiende la operatividad de la definición de "delito de cuello blanco" propugnada por EDWIN SUTHERLAND frente a aquellos que, como MARCUS FELSON, la rechazan y postulan su sustitución por la de "delitos de acceso especializado" ("crimes of specialized access"). Efectivamente, es cierto que, tal y como apunta este último autor, se han, digamos, popularizado los "cuellos blancos" en el desempeño de la actividad económica y, por tanto, ello ha facilitado un acceso más generalizado a la comisión de delitos económicos (por ejemplo, estafas, apropiaciones indebidas....). Sin embargo, también lo es que, aún hoy, un significativo grueso de esta delincuencia está protagonizada por personas que tienen un estatus social más alto y/o forman parte de las llamadas coloquialmente "élites económico-financieras". En palabras de ORTIZ DE URBINA GIMENO, "Too Much...", p. 513, "lo relevante es si todavía puede hablarse de diferencias sociales y de la existencia de una élite, y ello sin duda es el caso". No le resta valor a esta aseveración, la objeción relativa a la cierta vaguedad de los conceptos "élite" o "clase alta" porque -como apostilla atinadamente dicho autor- merece igualmente ser estudiado "aquello que no puede medirse con precisión" y superar así el conocido "prejuicio positivista". Como ha puesto de relieve el sociólogo norteamericano NEAL SHOVER, LH-Profesor Alfonso Serrano Gómez, p. 460, se ponga el acento en el delincuente o en las características del delito cometido como base de la definición de la criminalidad de cuello blanco, constituye una evidencia que "algunos (...) son delincuentes en virtud de cualquier definición. Se trata de personas de gran riqueza o poder, que forman parte de poderosas organizaciones, y cometen delitos de felonía". Y continúa el mencionado autor -no sin razón- que la cifra negra de delitos cometidos por estos delincuentes de las "altas esferas" es mucho mayor que los perpetrados por aquellos otros de "circunstancias económicas modestas" cuyos ilícitos, comparativamente, son cualitativa y cuantitativamente menos "destacables".
} 
estatus y mayor grado de conocimientos legales y económicos, no sólo lo alejarían de la imagen - estigmatizada- propia del delincuente marginal, sino que le permitiría tomar contacto con los centros de poder político y financiero ${ }^{93}$. Es más, mientras la inmensa mayoría de ciudadanos no se identifica con los delincuentes de corte violento, una parte -aunque cada vez menor- continúa justificando o empatizando ${ }^{94}$ con aquellos otros que, aprovechando la cercanía a cargos electos o a quienes están al frente de agencias reguladoras o grandes grupos empresariales, se enriquecen ilícita y/o delictivamente al tiempo que empobrecen las arcas públicas y minan la confianza depositada en las instituciones llamadas a representarles ${ }^{95}$.

8. En este punto, quisiera, no obstante, apuntar un matiz que estimo fundamental. La opinión social que merece la delincuencia de corte económico -asociada en muchos casos a la gestión de lo público y adoptando la forma de "corrupción"96 - ha cambiado significativamente en España a raíz de la crisis declarada en la primavera del 2008 y cuyos negativos efectos - pese a lo que se diga- aún persisten. En efecto, comparto, en la línea apuntada por BAJO FERNANDEZ en 1978, que también hoy se constataría una cierta "ausencia de negativa valoración social” motivada, entre otros factores, por el "aprecio a valores materiales como el éxito económico o el lucro", la carencia de "afectividad en torno al delito" o la "posición social del autor"

\footnotetext{
${ }^{93}$ Como ha señalado SHOVER, N., LH-Profesor Alfonso Serrano Gómez, p. 458, la esencia de los delitos de cuello blanco radicaría en el hecho de que son "cometidos por personas de riqueza y estatus respetable". Tales delincuentes en su opinión se caracterizarían "por sus vidas privilegiadas" en la medida en que disfrutan de una existencia acomodada alejada de la -mundana- preocupación por satisfacer las necesidades materiales básicas; gozan de una "situación en la jerarquía de respetabilidad"; y, por último, y no por ello menos importante, porque muchos de ellos ocupan "posiciones de autoridad en el estado u organizaciones privadas". Lo cual -continúa el citado autor- les permite "hacer que las cosas pasen", posibilidad ésta que no está al alcance de los "ciudadanos de cuello azul y propietarios de pequeños negocios".

${ }^{94} \mathrm{Me}$ estoy refiriendo a las típicas e informales conversaciones mantenidas entre amigos y/o conocidos en que, al hilo de la enésima trama descubierta, se deslizan frases tales como "de haber estado en su lugar yo también lo habría hecho". Eso sí, a continuación se apresuran en puntualizar "siempre y cuando tuviera la certeza de que ello no comportará una responsabilidad de corte penal" de detectarse y/o perseguirse la acción delictiva cometida.

${ }^{95}$ Así lo puso de manifiesto en su día BAJO FERNÁNDEZ, CPC (5) 1978, pp. 16-17, cuando concluyó "Esta imagen de honorabilidad e integridad, que cuidan muchos de crear y mantener, les facilita su relación con grupos de poder como la judicatura y el gobierno. A consecuencia de ello van adquiriendo poder e influencia que utilizará para la satisfacción de intereses personales".

${ }^{96}$ En un sentido técnico-jurídico cuando, periodísticamente, se utiliza el término "corrupción", en puridad, se están refiriendo al pack compuesto por los delitos de "prevaricación, cohecho, malversación de caudales públicos, fraude ilegal y tráfico de influencias". Un quinteto que ha devenido un clásico cuando se trata de perseguir los ilícitos penales conectados a la desviación y/o malas prácticas operadas en la administración de lo público y la actividad privada-empresarial que la circunda.
}

${ }^{97}$ Vid., BAJO FERNÁNDEZ, CPC (5) 1978, p. 20. 
disiento del mencionado autor, cuando añadía que el reproche social hacia este tipo de delincuencia crecía "en la medida en que la lesión deja de afectar intereses públicos para lesionar intereses privados, sobre todo a miembros del mundo económico o financiero". A mi juicio, ocurre, justamente, lo contrario. El cambio que se observa en la ciudadanía frente a la criminalidad de cuello blanco traería causa, directamente, de la visualización de los estragos que los delitos económicos han ocasionado en amplias -y humildes- capas sociales (pensemos en los preferentistas entre los que destacan el grupo formado por personas mayores y con baja formación). E indirectamente, tendría su origen en la identificación de los recortes perpetrados en los servicios públicos básicos $-\mathrm{y}$ el consiguiente desmantelamiento parcial del Estado del Bienestar- como uno de los costes derivados de su comisión ${ }^{98}$. De haberse cebado en exclusiva los negativos efectos de estos delitos en los patrimonios personales de las élites económico-financieras, estoy convencido de que el grueso de la población habría mantenido esa tradicional actitud de cierta indiferencia/complacencia hacia esta concreta manifestación criminal ${ }^{99}$.

9. Por otra parte, la delincuencia económica suele cometerse en el ejercicio de una profesión o en el marco de una estructura -más o menos compleja-como la empresa. Es precisamente este contexto profesional u orgánico-funcional el que proporcionaría a este colectivo las habilidades, competencias y oportunidades para desplegar la actividad delictiva. Ciertamente, más allá de las inconcretas y volátiles características personal-

\footnotetext{
${ }^{98}$ Una vinculación que puede ilustrarse perfectamente con el ejemplo de Bankia. Una entidad en la que las malas prácticas económico-financieras y -presuntamente-delictivas de unos pocos la condujeron a una quiebra no materializada gracias a los 22.500 millones de un rescate que, desgraciadamente, será sufragado por todos. Desde luego, en este cambio de percepción social experimentado en los últimos tiempos, habría jugado un papel fundamental la mejor formación de la que, en general, goza la población gracias -en parte- a la labor "pedagógica" desarrollada por los medios de comunicación que han mostrado un mayor interés por los distintos escándalos financieros, así como sus protagonistas, causas y consecuencias. Así lo ha puesto de relieve GEIS, LH-Profesor Alfonso Serrano Gómez, p. 319, cuando apunta que en la actualidad la opinión pública "exige unas prácticas comerciales justas y equitativas", una perspectiva que, a su juicio, resultaría acorde con el llamativo "crecimiento de las inversiones de la clase media" y a la que habría contribuido la mejor formación de la gente necesaria para "comprender más fácilmente los detalles de los abusos de poder".

${ }^{99}$ Por ello no estoy del todo de acuerdo con el planteamiento defendido, entre otros, por ZÚÑIGA RODRÍGUEZ, “Culpables, millonarios....”, pp. 37, 41, 47, cuando en diversas ocasiones a lo largo de su trabajo, sostiene que el conjunto de la ciudadanía no percibe el daño social causado por la criminalidad económica. Es posible que esta falta de concienciación existiera en décadas pasadas, pero, a mi juicio, habría perdido vigencia en la actualidad. A ello habría contribuido, entre otros factores, la mayor atención que, en algunos medios de comunicación, se presta -también- a la delincuencia socioeconómica, aunque -todavía- en menor medida que la dispensada a la de corte más violento (asesinatos, violaciones....) y, seguramente, de un tono más amarillento y sensacionalista.
} 
psicológicas que algunos autores han atribuido a estos delincuentes ${ }^{100}$, la oportunidad y el entorno devienen factores desencadenantes en la decisión de quebrantar la norma penal $^{101}$. A mi juicio, la delincuencia socioeconómica constituye uno de los ámbitos delictivos en que mayor partido puede extraerse a las llamadas teorías de la prevención situacional ${ }^{102}$ que, a diferencia de la criminología más "tradicional”, situarían el foco de atención en las circunstancias espacio-temporales que contribuirán a la comisión de los delitos en detrimento de las características personales del delincuente ${ }^{103}$. Los partidarios de este planteamiento más sociológico y menos biológico-psicológico, sostienen que el delito no se distribuiría de un modo aleatorio en el espacio y en el tiempo, sino que, contrariamente, se proyectaría en unos determinados lugares y momentos ("hot

${ }^{100}$ Paradigmática en este sentido fue, en su momento, la "teoría del psicograma" propugnada por MERGEN, quien, como recientemente ha puesto de relieve BAUCELLS LLADÓS, CPC (106) 2012, pp. 149-150, primó los factores internos sobre los externos como razones explicativas de esta tipología delincuencial. Según ha resumido el último de los autores citados, ocho rasgos de su personalidad estarían en el origen de su tendencia al delito: 1) el materialismo; 2) el egocentrismo y el narcisismo; 3) el dinamismo y la audacia; 4) la inteligencia pragmática; 5) la peligrosidad; 6) la hipocresía; 7) la neurosis; y 8) la inconsciencia de culpabilidad. Para una descripción más detallada de estos rasgos pueden consultarse, entre otros, el trabajo de ARMAND MERGEN publicado en la Revue Internationale de criminologie et de police technique (1970), bajo el título "La personnalité du criminel á col blanc", pp. 265-270. Un sucinto resumen de esta teoría lo encontrará el lector en los trabajos de BAJO FERNÁNDEZ, CPC (5) 1978, pp. 8-9 y HERRERO HERRERO, Los delitos económicos. Perspectiva jurídica y criminológica, Ed. Ministerio del Interior, Madrid, 1992, pp. 495-496.

${ }^{101}$ Una aspecto ya enfatizado en los años 80 por el maestro alemán TIEDEMANN, "La criminalidad económica como objeto de investigación", (Bacigalupo Zapater, Trad.), CPC (19) 1983, cuando señaló que "la criminalidad económica es criminalidad en el ejercicio de la profesión o en ocasión del mismo ('occupational crime'), en otras palabras, la criminalidad de los que tienen actividades en la vida económica" (p. 172). Una idea sobre la que siguen insistiendo -con razón-diversos autores en la actualidad, entre otros, BAUCELLS LLADÓS, CPC (106) 2012, pp. 150-155, quien las combina con las teorías de la anomia y de la asociación diferencial como bases explicativas de esta tipología criminal; FERNÁNDEZ TERUELO, Instituciones..., pp.78-80, para quien el contexto jugaría un papel más determinante que las condiciones personales del sujeto en la delincuencia socioeconómica trayendo a colación los trabajos elaborados al respecto por el criminólogo WEISBURG y el sociólogo WARING en los que, precisamente, acentuaron los aspectos situacionales sobre los meramente biopsicológicos.

${ }^{102}$ En esta línea se ha expresado en nuestra doctrina AGUSTINA SANLLEHÍ, PC (10) 2010, pp. 394, quien ha defendido la especial utilidad de la "teoría de la actividad rutinaria" en el análisis criminológico de la delincuencia intraempresarial, no sólo en la medida en que aportaría "una explicación fenomenológica respecto de dónde surge el hecho delictivo, sino porque conduce a descubrir la causación criminógena de conductas delictivas entre 'personas normales', a partir de la ausencia de controles internos y de dispositivos de vigilancia natural en la vida interna de la empresa".

${ }^{103}$ Como ha señalado, entre otros, BERMEJO, M., "Elección racional, oportunidad para delinquir y prevención situacional: la utilidad de este enfoque para el estudio de la delincuencia empresarial", en LH-Marcus Felson MIRÓ / AGUSTINA / MEDINA / SUMMERS (eds.), Ed. Dykinson, Madrid, 2015 pp. 314-315, la prevención situacional en tanto técnica de política criminal no centraría su atención -directa- en la figura del infractor, sino en la "identificación de situaciones criminógenas (...) con la finalidad de intervenir sobre ellas, para rediseñarlas de forma tal que dejen de proveer incentivos para la comisión de infracciones". 
spots" o "puntos calientes") ${ }^{104}$. La noción de oportunidad deviene el rasgo común a estas distintas "teorías" preventivo-situacionales dado que la concentración del delito en un específico lugar o momento está íntimamente conectada con las oportunidades que éstos ofrecen para la comisión de los ilícitos penales ${ }^{105}$.

10. Entre las distintas "teorías del delito como oportunidad" 106 , ha alcanzado un notable éxito y notoriedad el denominado "enfoque de las actividades cotidianas" ("routine activity approach") formulado originariamente en 1979 por COHEN y FELSON ${ }^{107}$ y que el segundo después desarrollaría en su afamada monografía Crime and Everyday Life de la que se ya contabilizan cuatro ediciones ${ }^{108}$. En su formulación primigenia dicho enfoque empezó siendo una explicación de las infracciones predatorias de contacto directo ("direct-contact predatory violations"). Esto es, aquellas que requieren del contacto entre el infractor y la persona u objeto que el primero tiene la intención de

${ }^{104}$ Vid., entre otros, MEDINA ARIZA, Politicas y estrategias de Prevención del delito y Seguridad ciudadana, Eds. Edisofer/Bdef, Madrid-Montevideo, 2011, p. 326.

105 Vid., entre otros, MEDINA ARIZA, Políticas..., p. 327.

${ }^{106}$ Como han apuntado en España, entre otros, AGUSTINA / REALES, "En la mente de un asaltante de viviendas: estudio cualitativo de una muestra de autores de robo en casa habitada", REIC (11) 2013, p. 6, el "enfoque de las actividades rutinarias", la "teoría del patrón delictivo" y "la perspectiva de la elección racional" se agruparían entre las "teorías de la oportunidad" en el seno de la denominada criminología ambiental o situacional. Ahora bien, como matizan dichos autores, mientras en las dos primeras se pone un mayor acento en "aspectos relativos al lugar del delito, del delincuente y de la víctima", la "teoría de la elección racional" se centra "más en la persona del autor del hecho delictivo, sus motivaciones, su análisis de costes y beneficios (siempre en relación a la comisión del hecho y el objetivo del delito)". Para una sucinta descripción de todas ellas, puede consultarse el trabajo de FELSON / CLARKE, con el gráfico título "La ocasión hace al ladrón. Teoría práctica para la prevención del delito" (Díaz i Pont/Felip i Saborit, Trads.), en Convivencia ciudadana, seguridad pública y urbanismo. Diez Textos fundamentales del panorama internacional, ORTIZ DE URBINA GIMENO / PONCE SOLÉ (coords.), Eds. Fundación Democracia y Gobierno Local/Diputació de Barcelona, Barcelona, 2008, p. 196, donde matizan que resulta más apropiado hablar de "enfoques" que de verdaderas teorías porque "quedan por atar demasiados cabos sueltos" y "ninguna es una teoría formal y completa". También entiendo de interés la breve, pero precisa descripción realizada al respecto por AGUSTINA SANLLEHÍ, PC (10) 2010, pp., 393-396.

${ }^{107}$ COHEN, L.E / FELSON, M., "Social Change and Crime Rate Trends: a Routine Activity Approach", ASR (44), pp. 588-608, un artículo que, en opinión de ORTIZ DE URBINA GIMENO, “Too much...”, p. 498, ha alcanzado la categoría de clásico de la criminología y cuyo abstract, inusualmente,concentraría uno de los mayores grados de información importante de cuantos se han publicado en la historia de esta disciplina. Un sentir compartido por REDONDO ILLESCAS / GARRIDO GENOVÉS, Principios de criminología, (4 ${ }^{\mathrm{a}}$ ed.), Ed. Tirant, Valencia, 2013, p. 489, quienes califican al enfoque de las actividades cotidianas o rutinarias como la "teoría situacional más importante y citada en criminología".

${ }^{108}$ Como ha apuntado recientemente ORTIZ DE URBINA GIMENO, “Too much...”, p. 500, se trata de la obra individual más relevante de FELSON (las tres primeras en solitario y la última que data del 2010 en coautoría con RACHEL BOBA), y en sus distintas ediciones "ha ido incrementando el número de aplicaciones de su teoría", entre otras, la relativa a sustituir la categoría de la "delincuencia de cuello blanco" por la de "delitos de acceso especializado". 
apropiarse o lesionar ${ }^{109}$. En su base se partió de la premisa de que la comisión de tales crímenes requería de una triple convergencia en el tiempo y en el espacio: "un posible delincuente, un objetivo apropiado y la ausencia de un vigilante adecuado al delito" ${ }^{\prime 10}$. El riesgo será mayor de confluir cuatro factores agrupados en torno al acrónimo "VIVA" (Valor, Inercia, Visibilidad y Acceso) ${ }^{111}$, existiendo una íntima correlación entre la prevalencia de tales delitos y los cambios sociales acaecidos a raíz del desarrollo tecnológico y la estructura ocupacional ${ }^{112}$.

11. A mi juicio, la utilidad práctica de las “teorías de la oportunidad” vendría determinada por la información que, en principio, pueden proporcionar acerca de las condiciones y/o elementos que fomentan la criminalidad económica. Una información que, en última instancia, debería ser crucial en la adopción de las distintas herramientas y/o estrategias - penales y no penales- cuya implementación permitirá prevenirlas y, de no lograrlo, sancionarlas más adecuadamente. Ciertamente, el conocimiento de las razones que mueven al delincuente económico, los mecanismos de autoprotección de que dispone la propia víctima y los entornos que favorecen su comisión ayudarán -o deberían ayudar- al legislador a activar las medidas (de naturaleza extra-penal y/o estrictamente penal) idóneas para, respectivamente, "desactivar" las motivaciones del victimario; aumentar las capacidades autoprotectoras de las víctimas y contrarrestar los efectos criminógenos vinculados a las propias corporaciones públicas o privadas en que los primeros suelen operar.

109 Vid., ORTIZ DE URBINA GIMENO, “Too much...”, p. 500, nota 11, si bien como también señala este autor dicho planteamiento se ha exportado en España a un ámbito no abarcado por FELSON como la cibercriminalidad de la mano de MIRÓ LLINARES en su monografía sobre el cibercrimen en que, como apunta el propio FELSON en su condición de prologuista, se examina, brillantemente, "la relación entre el cibercrimen y el amplio mundo de la actividad social y empresarial" (p. 13).

${ }^{110}$ Vid., FELSON / CLARKE, "La ocasión...”, p. 197.

${ }^{111}$ En su opinión, FELSON / CLARKE, “La ocasión...”, p. 198, se trata de cuatro variables aplicables al infractor predatorio en atención a las que, respectivamente, dicho delincuente mostraría interés por los objetos a los que atribuye valor; por los de menor peso (inercia); de mayor exposición (visibilidad) y de mejor acceso en el sentido que favorecen más oportunidades a su apropiación (p.e., el diseño de las calles o su ubicación próxima a la puerta). En definitiva, el delito depredatorio tendrá lugar cuando el infractor encuentre un objetivo adecuado en ausencia de un vigilante que dificulte su apoderamiento (no debiendo identificar a este último solamente con un agente de la autoridad). Ello significa que puede producirse un incremento de la criminalidad sin necesidad de que aumente el número de delincuentes, siempre y cuando existan más objetivos o menor sea el número de vigilantes. De la misma forma que crecerán las tasas de delincuencia cuando se produzcan cambios sociales que proporcionen más oportunidades delictivas sin que, paralela y necesariamente, se haya registrado un idéntico crecimiento de la "motivación criminal".

${ }^{112}$ Ciertamente, en dicho planteamiento se pone un especial acento en los cambios sociales acaecidos en los planos tecnológico y organizativo-social como motores de la delincuencia de corte predatorio, FELSON / CLARKE, “La ocasión...”, p. 199. 
12. Así, con respecto al delincuente económico, puede afirmarse, sin riesgo a equivocarse -demasiado-, que la obtención de un beneficio o lucro económico - directo o indirecto- constituye, de facto, uno de los principales incentivos que conduciría a estos sujetos socializados a optar por el quebrantamiento de la ley -también penalcomo medio para lograrlo ${ }^{113}$. De igual modo puede, intuitivamente, concluirse que el mundo profesional y/o empresarial en el que muchos de estos operan, favorecería una elección -algo- más racional que la esperada del -marginal y menos instruido- delincuente callejero y/o violento ${ }^{114}$. Esta mayor cuota de racionalidad que, en principio, podría presumirse del delincuente del cuello blanco se proyectaría sobre dos planos diferenciados pero complementarios. En primer lugar, podría colegirse que quien está más formado y goza, por tanto, de mayores posibilidades para informarse sobre las posibles consecuencias negativas de sus actos criminales, estaría en mejor disposición para analizar, con carácter previo, los distintos costes (reputacionales y jurídicos) y beneficios que conllevará su comportamiento de ser detectado, perseguido y finalmente

${ }^{113}$ Así lo han puesto de relieve en nuestra doctrina, entre otros, BAUCELLS LLADÓS, CPC (106) 2012, p. 147; REDONDO ILLESCAS / GARRIDO GENOVÉS, Principios..., p. 786, quienes señalan que los delitos económicos tienen como elemento común la obtención de un beneficio del autor a costa de una víctima que no sospecha que está siendo objeto de un engaño; $y$ en la doctrina foránea, entre otros muchos, GEIS, LH-Profesor Alfonso Serrano Gómez, p. 320, quien muy gráficamente apunta "La observación más común sobre el delito de cuello blanco cometido por parte de aquellos que parecen estar tan acomodados que no necesitan tener que infringir la ley, es que su motivación es la avaricia" - y más adelante apostillaes cometido con mucha frecuencia por aquellos que viven muy bien, pero no obstante se ven obligados a acaparar una cuota aún mayor de riqueza". Resulta evidente que el sistema capitalista por "definición" lejos de constituir un freno se erige en un "acelerante" desde el momento en que la acumulación de bienes y propiedades se visualiza como medida del éxito personal y el estatus social. Y claro está, ello puede conseguirse por cauces legales o bien, a modo de atajo, también canalizarse por vías ilícitas.

${ }^{114}$ Así lo ha expresado muy gráficamente, entre otros, SHOVER, NEAL, LH-Profesor Alfonso Serrano Gómez, p. 468, cuando concluye "La intuición sugiere que los delincuentes de cuello blanco deberían poder emplear una mayor racionalidad que los delincuentes callejeros. Por algo los contextos en que adoptan sus decisiones son destacadamente diferentes a lo que es habitual para los últimos; muchos delincuentes de cuello blanco viven y trabajan en mundos en los que se espera, se fomenta, se sigue y se recompensa la conducta racional". Como ha apuntado recientísimamente BERMEJO, MATEO, "Elección racional...", p. 311, el infractor -como cualquier persona- ve limitada la racionalidad de sus acciones en atención al tiempo, recursos e información de que dispone en el momento en que toma la decisión delictiva. No obstante -continúa-, aquellos individuos que gozan de una mayor profesionalidad en atención al sector en el que interactúan desarrollan aptitudes y conocimientos con los que "puede reducir el riesgo e incrementar la eficacia de sus proyectos delictivos a través de la planificación y la cuidadosa selección de objetivos, del incremento de los contactos y vínculos, así como de una más adecuada información de la intervención policial y judicial. Esta profesionalización - que según la doctrina dominante caracteriza a la delincuencia económica y al crimen organizado- permite referir a una mayor racionalidad de los infractores". En definitiva, como ha puesto de relieve ORTIZ DE URBINA GIMENO, "El derecho penal económico...", p. 141, "la teoría de la elección racional, incluyendo la teoría de la disuasión, parecen hechas a medida (o a mejor medida) de este tipo de delincuencia". 
condenado ${ }^{115}$. En segundo lugar, podría deducirse igualmente que aquéllos más dotados -intelectualmente hablando- cuentan con mayores recursos para idear, perfeccionar e implementar las denominadas "técnicas de neutralización y/o racionalización" que, a la postre, se erigen en uno de los obstáculos que impiden la comisión de una acción ilegal y/o delictiva ${ }^{116}$. En definitiva, las teorías de la elección racional y de la neutralización pueden ayudarnos a entender por qué, a diferencia del delincuente clásico, el de cuello blanco ostenta una mejor situación para ponderar los costes y beneficios aparejados a la acción criminal, desmontar las barreras morales que la dificultan y justificar, en fin, su comportamiento contrario al derecho.

\section{b) La empresa como factor criminógeno ¿Es la RPPJ la mejor respuesta para com- batir esta realidad?}

1. Como adelanté, las empresas, en ocasiones, son instrumentalizadas para dificultar la detección y posterior persecución del delito socioeconómico perpetrado y en otras -alternativa o cumulativamente- se erigen en las destinatarias finales del beneficio

\footnotetext{
${ }^{115}$ En este sentido, se han pronunciado, entre otros, NIETO MARTÍN, “Cumplimiento normativo...", pp. 55-56, para quien tanto el autor individual como la propia corporación en que opera "están en una mejor posición para evaluar costes y beneficios que los delincuentes en el marco de la criminalidad más clásica -y continúa- se trata de personas expertas y que las actividades que realizan dentro de su actividad (...) se repiten a lo largo del tiempo, por lo que existen mayores posibilidades de efectuar cálculos y hacer correcciones".

116 Como han señalado REDONDO ILLESCAS/GARRIDO GENOVÉS, Principios..., pp. 790-791, los delincuentes de cuello blanco como los comunes también utilizan las técnicas de neutralización descritas por Sykes y Matzda (1957) y aplicadas por Kieffer y Sloan III (2009) a los primeros. De hecho, estas técnicas - continúan los citados autores- devienen uno de los factores fundamentales en la decisión delictiva, por cuanto le permiten "superar el escrúpulo moral asociado al acto ilícito mediante la minimización de la culpa y la protección de la autoestima". En la misma línea, se ha pronunciado recientemente NIETO MARTÍN, "Cumplimiento normativo...", p. 58, quien ha destacado el éxito que dicha teoría desarrollada en el ámbito de la delincuencia juvenil ha alcanzado en la criminalidad económica, donde se ha constatado la relevancia de algunas de estas técnicas y, muy especialmente, la relativa a "la apelación a que se trata de una conducta normal y extendida y esgrimir un hipotético derecho a su realización". Un rasgo que, como ha apuntado MIRÓ LLINARES, El cibercrimen..., pp. 247-248, compartiría con su "alter ego" virtual, el llamado ciberdelincuente económico quien, al igual que su homólogo en el espacio físico, además de contar con un nivel de estudios superior al clásico y tener un buen concepto de sí mismos, no se autodefinen como delincuentes ni entienden que sus comportamientos sean delictivos. Y que también se observa en la delincuencia vinculada al fenómeno de la corrupción con el que la criminalidad de cuello blanco, dicho sea de paso, está muy emparentada. Así lo ha puesto de relieve ORTIZ DE URBINA GIMENO, "Política criminal contra la corrupción: una reflexión desde la teoría de la pena (o viceversa), en Garantías constitucionales y Derecho penal europeo, MIR PUIG / CORCOY BIDASOLO (dirs.), GÓMEZ MARTÍN (coord.), Ed. Marcial Pons, Madrid, 2012, p. 398, para quien las "estrategias de neutralización" tienen un "amplio campo de juego" a modo de excusa o justificación "de la propia conducta delictiva".
} 
ilícito obtenido a resultas de su comisión ${ }^{117}$, haciendo de ellas un primigenio ámbito de oportunidad delictiva ${ }^{118}$. Con motivo de la globalización y la transnacionalización del tráfico mercantil, estas organizaciones económico-jurídicas, además de constituir un grave peligro para la indemnidad de los bienes personales y patrimoniales de los ciudadanos, han devenido también un riesgo cierto para la propia estabilidad económico-financiera de los Estados y los entes supraindividuales en que se aglutinan ${ }^{119}$. La significación de la empresa como factor criminógeno y, consiguientemente desencadenante de la delincuencia socioeconómica es una realidad que, más allá de la concreta solución político-criminal adoptada para combatirla, ni puede ni debe ser soslayada por los legisladores nacionales y supranacionales ${ }^{120}$.

${ }^{117}$ Una realidad que han puesto de relieve en nuestra doctrina, entre otros, FERNÁNDEZ TERUELO, Instituciones..., pp. 25 y ss., para quien, precisamente, el "uso y abuso del instrumento societario (la empresa)" y la incidencia de sus numerosos instrumentos en la comisión del delito se erigiría, actualmente, desde una perspectiva criminológica y jurídica, en su elemento central. Hasta tal punto que habría dotado de autonomía -y justificado-al propio "Derecho penal económico y de la empresa" -y añadiría yo- explicaría la consolidación y creciente importancia de esta rama del Derecho penal en los planos académico-teórico y práctico-judicial.

${ }^{118}$ Este aspecto, digamos, "organizativo" de la delincuencia de cuello blanco ha sido, recientemente, puesto de relieve, entre otros, por BAUCELLS LLADÓS, CPC (106) 2012, para quien las estructuras propias de las medianas y grandes empresas serían utilizadas para la comisión de estos ilícitos penales. Un binomio éste igualmente acentuado por MONTANER FERNÁNDEZ, Gestión empresarial y atribución de responsabilidad penal. A propósito de la gestión medioambiental, Ed. Atelier, Barcelona, 2008, pp. 35-36, cuando señala que “(...) la comisión de un delito socioeconómico -es- el resultado de la interacción de varios sujetos a través del funcionamiento de estructuras organizativas estables que operan en el mercado". ${ }^{119}$ Los movimientos especulativos protagonizados por los grandes -y anónimos- fondos privados de inversión internacional han puesto en jaque la deuda soberana de varios países europeos y con ello, directamente, la propia estabilidad del euro e, indirectamente, la existencia del Estado del Bienestar del que todos nos beneficiamos. Una situación en la que, dicho sea de paso, han cooperado activamente las agencias de calificación cuya actividad se ha visto obligada a reglar ex post la (des)Unión Europea.

${ }^{120}$ De hecho, el protagonismo de estas corporaciones es tal que, en estrictos términos criminológicos, en el ámbito de la criminalidad de cuello blanco conviven dos categorías diferenciadas pero íntimamente conectadas como son el delito ocupacional (ocupational crime) y el corporativo (corporative crime). Así lo han puesto de relieve, en nuestra doctrina, entre otros, NIETO MARTíN, "Cumplimiento normativo...", p. 51; AGUSTINA SANLLEHÍ, PC (10) 2010, pp. 373-376; y, por supuesto, los criminólogos, entre otros muchos, SHOVER, NEAL, LH-Profesor Alfonso Serrano Gómez, pp. 460-461. Esta pareja conceptual se completaría con el llamado delito del empleado (employee crime). En opinión de AGUSTINA SANLLEHÍ, PC (10) 2010, p. 353, nota. 3, esta categoría haría referencia a los ilícitos penales cometidos en el seno de la empresa por los empleados y, a diferencia del delito corporativo, ésta última no se presentaría como la beneficiara, sino, contrariamente y, en principio, como la víctima directa o indirecta. Como dicho autor matiza -siguiendo en este punto a SCHÜNEMANN- estamos ante una manifestación de la llamada "criminalidad intraempresarial" (Betriebskriminalität) en contraposición a la "criminalidad empresarial ad extra" (Unternehmenskriminalität). En la primera se atentaría contra bienes jurídicos de la empresa mientras que en la segunda se lesionarían los intereses de los terceros que con ella se relacionan, esto es, los clientes, consumidores, proveedores o acreedores (p. 355). 
2. Como ha puesto de relieve la doctrina especializada, las grandes y organizativamente complejas empresas devienen un "foco de peligro" que alentaría la comisión de hechos delictivos por parte de sus administradores y trabajadores ${ }^{121}$. Ciertamente, la integración de un individuo en el seno de las corporaciones mercantiles posibilitaría la realización de comportamientos contrarios al Derecho -también penal-que aisladamente considerados no habría perpetrado ${ }^{122}$. En opinión de estos autores, existen evidencias empíricocriminológicas - no irrefutablemente contrastadas- que demostrarían cómo las propias organizaciones condicionarían y/o instrumentalizarían el comportamiento individual de quienes actúan en su beneficio o provecho. O más concretamente, se sostiene que anidaría en ellas un "espíritu criminal de grupo" "123 que fomentaría el aprendizaje por

${ }^{121}$ En este sentido, entre otros muchos, destacaría a dos autores que, pese a sus contrarios puntos de visto en torno a la legitimidad y necesidad de la RPPJ, se han ocupado de los efectos criminógenos vinculados a las grandes empresas y corporaciones, FEIJOO SÁNCHEZ, Sanciones para empresas por delitos contra el medio ambiente. Presupuestos dogmáticos y criterios de imputación para la intervención del Derecho Penal contra las empresas, Ed. Civitas, Madrid, 2002, pp. 34-48 y 147-154; y NIETO MARTÍN, La responsabilidad penal..., pp. 37-47. Un punto en que resultan de obligada cita las monografías elaboradas por SCHÜNEMANN, Unternehmenskriminalitat und Strafrecht, Heymanns, Köln-Berlin-Bonn-München, 1979; y HEINE, G., Die Strafrechtliche Verantwortlichkeit von Unternehmen: von individuellem Fehlverhalten zu Kollektiven Fehlentwicklungen, insbesondere bei Grossrisiken, Nomos, Baden-Baden, 1995.

${ }^{122}$ Vid., FEIJOO SÁNCHEZ, Sanciones para empresas..., p. 148; NIETO MARTÍN, La responsabilidad penal..., p. 40, quien, no sin cierta dosis de cautela dada la inexistencia de una gran evidencia empírica al respecto, mantiene la existencia de "indicios" que avalarían de "forma razonable" cómo las organizaciones determinarían "el comportamiento de quienes actúan en su interior". También hacen referencia a la idoneidad de la empresa como lugar propicio para la proliferación de "definiciones favorables al delito", así como el desarrollo de "racionalizaciones" que neutralizarían el "efecto motivador de las normas éticas o sociales", ORTIZ DE URBINA GIMENO, "Sanciones penales contra empresas en España (Hispánica societas delinquere potest"), en Compliance y teoría del Derecho penal, KUHLEN / MONTIEL / ORTIZ DE URBINA (eds.), Ed. Marcial Pons, Madrid, 2013, pp. 269-270; BERMEJO / PALERMO, "La intervención delictiva del compliance officer", en Compliance y teoría del Derecho penal, KUHLEN / MONTIEL / ORTIZ DE URBINA (eds.), Ed. Marcial Pons, Madrid, 2013, p. 174.

${ }^{123}$ Una forma desviada de cultura preventiva que NIETO MARTÍN, "Cumplimiento normativo...”, p. 52, define como "un conjunto de actitudes, técnicas de realización de hechos delictivos, de argumentaciones, incluso de usos lingüisticos compartidos por los miembros de la organización que alienta y justifica, dando por ejemplo nombres más amables (ahorro fiscal, contabilidad creativa), a los comportamientos delictivos". Varios son los factores que, en su opinión, estarían en el origen de esta mala cultura corporativa: a) uno principal y endógeno como el liderazgo en la organización que actuaría de "arriba a abajo" y que expandiría la cultura del líder en el seno de la empresa tanto entre los ya integrados como aquéllos que lo serán en el futuro por medio de los correspondientes procesos de selección; b) otros de orden exógeno tales como los propios valores compartidos por las empresas que interactúan en idéntica rama de actividad (la industria armamentística y farmacéutica o el sector de la construcción) y ante la necesidad de mantener su posición en el mercado optan por la comisión de delitos (corrupción de funcionarios, publicidad engañosa...); y c) también de carácter sistémico en la medida en que -se dice-el capitalismo devendría el "caldo de cultivo" propicio para la proliferación de comportamientos ilícito-penales dada la consustancial maximización del beneficio en el menor plazo posible que en dicho sistema se propugna. 
sus integrantes - una idea en su día sugerida por SuTHERLAND- de conductas delictivas y técnicas neutralizadoras destinadas a bloquear los valores internalizados en los distintos procesos de socialización ${ }^{124}$. Una neutralización que se vería favorecida por la difuminación de la responsabilidad producto de la fragmentación inherente a la división horizontal y vertical del trabajo y -el no menos relevante- proceso de "despersonalización” que garantizaría la supervivencia de la organización empresarial con independencia de las concretas y fungibles personas que, en cada momento, la componen $^{125}$.

3. Junto a este factor patógeno, se mencionan otros de corte más neutro que harían de estos complejos entes una fuente de potenciales infracciones penales. Así en una expresión que ha hecho fortuna se insiste en la "irresponsabilidad penal organizada/ estructurada/institucionalizada" propia de las grandes sociedades mercantiles ${ }^{126}$. Se dice que el delito no constituiría el producto o resultado de una conducta individual claramente identificada, sino la suma o acumulación de varias protagonizadas por personas que gozan de una capacidad decisoria limitada y un manifiesto déficit informativo ${ }^{127}$. Es más, la responsabilidad penal cuando de delitos corporativos se trata, normalmente,

${ }^{124}$ Vid., FEIJOO SÁNCHEZ, Sanciones para empresas..., p. 149; NIETO MARTÍN, La responsabilidad penal..., p. 40; EL MISMO, “Cumplimiento normativo...”, pp. 51-52, como señala, gráficamente, este último autor "El contacto con los valores del grupo les aportaría las razones necesarias (...) para dejar atrás sus escrúpulos morales y realizar el delito".

${ }^{125}$ Vid., FEIJOO SÁNCHEZ, Sanciones para empresas..., p. 148, para quien la mencionada instrumentalización del individuo por la empresa vendría condicionada también por la fungibilidad de las personas físicas que la integran, una realidad que ilustra trayendo a colación lo sucedido en el ámbito de los delitos contra el medio ambiente; NIETO MARTÍN, La responsabilidad penal..., p. 40 y, más recientemente, EL MISMO, "Cumplimiento normativo...", pp. 58-59, donde concluye "el sujeto percibe que el comportamiento es obra de un colectivo, donde él es simplemente un engranaje más. La estructura jerárquica y la división de funciones llevan a que los individuos no se ocupen por aquello que más allá de su valor e igualmente a que con facilidad puedan alegar que se vieron forzados a realizar el comportamiento con el fin de mantener su puesto de trabajo".

${ }^{126}$ En este sentido se han expresado, entre otros, HEINE, G., "Modelos de responsabilidad jurídico-penal originaria de la empresa", GÓMEZ-JARA DÍEZ (trad.), en Modelos de autorresponsabilidad penal empresarial. Propuestas globales contemporáneas, GÓMEZ-JARA DÍEZ (ed.), Ed. Thomson-Aranzadi, Cizur Menor, 2006, p. 27, quien concluye "Cuanto más estructurada esté la empresa en torno a la diferenciación funcional y menos en torno a la jerarquía lineal, más podrá diluirse, desde el punto de vista jurídico-penal, el potencial del autor en funciones operativas y estratégicas. Por lo tanto, la configuración organizativa de la empresa moderna puede conducir a una 'irresponsabilidad individual estructurada".

${ }^{127}$ En este sentido, se han pronunciado, entre otros muchos en nuestra doctrina, FEIJOO SÁNCHEZ, Sanciones para empresas..., p. 37; NIETO MARTÍN, La responsabilidad penal..., p. 39; y MONTANER FERNÁNDEZ, Gestión empresarial..., p. 39, trabajos todos ellos donde el lector encontrará numerosas referencias bibliográficas a la doctrina alemana. 
no se concentraría en la cúspide de la organización (los cargos directivos), sino en los mandos intermedios de corte ejecutivo o técnico ${ }^{128}$.

4. Una situación a la que contribuirían dos factores. Por un lado, el recurso a la delegación como mecanismo de transferencia de la competencia y, consiguientemente, de la imputación desde los cuadros superiores a los intermedios e inferiores, reteniendo los primeros meras funciones supervisoras y/o coordinadoras y los segundos, fundamentalmente, ejecutivas. Y, como consecuencia de lo anterior, un alejamiento de la ejecución material del hecho con respecto a las personas que ocupan los puestos más altos en el organigrama y su acercamiento a quienes ostentan los cargos menos significativos -y fungibles-. Y, por otro lado, esta localización de la responsabilidad individual en los estratos más bajos de la empresa, tendría lugar mediante un intencionado proceso de deslizamiento del riesgo materializado en la designación de chivos expiatorios -incluso voluntarios- que asumirían en solitario toda la responsabilidad penal de los hechos cometidos por los individuos situados más arriba ${ }^{129}$. Una heteroimputación o autoimputación consciente que convendría tanto a la dirección de la empresa como a los distintos operadores del sistema de Justicia Penal (jueces de instrucción, fiscales, defensores, agencias reguladoras,...) que verían como la compleja y ardua investigación se cierra en un tiempo récord.

5. La canalización de la información deviene el último de los factores que contribuyen a la comisión de delitos en las - grandes- empresas ${ }^{130}$. Todo aquél que tiene la intención de eludir la responsabilidad penal hará lo imposible por destruir o dificultar todo rastro informativo acerca de su comisión. Lo hará tanto el trabajador frente a la propia corporación como ésta última ante la Administración o Agente regulador que supervisa el cumplimiento de la normativa en cuestión (prevención del blanqueo de capitales; deberes

\footnotetext{
${ }^{128}$ Así lo han señalado, entre otros, ORTIZ DE URBINA GIMENO, “Sanciones penales...”, pp. 268-269, para quien en la empresa "existe la posibilidad de trasladar "hacia abajo" la responsabilidad", de tal manera que la imputación recaiga sobre el último que intervino aunque la instrucción procediera de un mando superior. Lo cual -a su juicio-dificultaría la internalización de la conminación penal de los directivos que siempre podrán responsabilizar a otro que se encuentre por debajo y, consecuentemente, el proceso de detección y, en su caso, sanción del auténtico autor.

${ }^{129}$ En este sentido, señala FEIJOO SÁNCHEZ -siguiendo a varios autores alemanes-, Sanciones para empresas..., p. 46, que la creación de un "cabeza de turco" puede resultar económicamente muy rentable a la empresa deviniendo la responsabilidad penal un coste más a computar anulando así sus efectos preventivo-generales.

${ }^{130}$ Sobre esta cuestión recomiendo la sucinta, pero documentada descripción realizada por NIETO MARTín, La responsabilidad penal..., pp. 41-42 y, últimamente lo expuesto en el trabajo "Cumplimiento normativo...", pp. 54-55.
} 
impuestos en materia tributaria o seguridad en el trabajo...). Partiendo de la premisa de que la información es poder, es posible que la omertà informativa se convierta en parte de la cultura corporativa y los retenedores de competencias supervisoras se escuden en el desconocimiento de las actividades delictivas perpetradas por quienes están por debajo como forma de eludir la propia responsabilidad penal. De hecho, nada impide que los propios subordinados también estén interesados en dificultar la información con la finalidad de aparecer como más resolutivos y capacitados frente a otras unidades departamentales, ganándose con ello el favor de la dirección.

6. Ahora bien, llegados a este punto, bueno sería plantearse la oportunidad de sancionar de forma adicional - penal o administrativamente- al ente colectivo del que se habría servido la persona física para cometer el delito socioeconómico y entorpecer así su efectiva detección y posterior persecución penal. Ello podría lograrse adoptando tres posibles soluciones de menor a mayor grado de intensidad punitiva. La primera, no demasiado explotada entre nosotros ${ }^{131}$, vendría determinada por el desplazamiento de la responsabilidad de la propia persona jurídica al hermano pequeño del Derecho penal, esto es, el Derecho administrativo sancionador. Esta opción, que podría construirse tomando como ejemplo el derecho contravencional alemán, además de no quebrantar los principios y garantías consustanciales al Derecho penal, se ha dicho podría tener unos efectos preventivo-generales similares a los atribuidos a la que constituye la manifestación última del Derecho punitivo.

7. Cual "ensayo clínico" compara ORTIZ de URBInA Gimeno ${ }^{132}$ la eficacia preventiva de la combinación "RPPJ/Derecho penal para individuos" versus "Derecho administrativo para la empresa/Derecho penal para los individuos", concluyendo que "no hay en principio ningún argumento preventivo al uso que justifique el uso preferente" de la primera sobre la segunda. Una conclusión que cimenta en la aplicación a ambas "fórmulas" de los tres elementos que permiten calibrar el coste esperado o eventual de la "prevención por medio de la amenaza de sanción": gravedad, probabilidad y celeridad en la imposición de la sanción. Dada la imposibilidad natural de imponer penas de prisión a las personas jurídicas, entiende que la "ventaja comparativa del Derecho

${ }^{131}$ Una opción por la que ha apostado, recientemente, ORTIZ DE URBINA GIMENO, "Sanciones penales....”, p. 282, quien, a propósito de la hipotética incorporación de la RPPJ al Derecho alemán, ha concluido, siquiera provisionalmente, que ésta "en general añade poco a la responsabilidad administrativosancionadora" y, contrariamente, "donde esta última funciona (....) la RPPJ tiene un menor campo de juego y puede traer consigo problemas que hagan que, considerando globalmente sus costes y los beneficios, el cambio no merezca la pena y por tanto se oponga al principio de ultima ratio".

${ }^{132}$ Vid., ORTIZ DE URBINA GIMENO, "Sanciones penales....", pp. 272-275. 
penal parece diluirse de forma importante". Una ventaja que sí proporcionarían las sanciones administrativas con respecto a la probabilidad y celeridad en su imposición, porque - a su juicio- las menores garantías y grado de formalización del procedimiento administrativo, facilitarían la consecución de la "efectiva condena de los acusados" en un menor tiempo. Hasta aquí estaría de acuerdo con él. Sin embargo, no creo, que puedan equiparse - tal y como hace dicho autor- los costes reputacionales aparejados a ambas sanciones, precisamente, porque, como reconoce ORTIZ DE URBINA, dicho coste depende más de las "valoraciones sociales y la resonancia mediática de los casos" que "de la calificación del hecho como ilícito penal o administrativo". Siendo cierto que la ciudadanía podría desconocer ex ante la calificación jurídica que merezca la contribución de la persona jurídica en la comisión del delito. También lo es que su canalización en el proceso penal imprime al hecho una carga comunicativo-simbólica adicional a la proporcionada de dirimirse en vía administrativa cuya intensidad dependerá del grado de atención dispensado por los medios de comunicación. Una atención que, claro está, vendrá condicionada por la propia relevancia mediático-social de la entidad o sociedad implicada, tal y como se ha podido constatar en la imputación y posterior procesamiento del FC Barcelona en el llamado "Caso Neymar". A lo anterior cabría sumar-como también apunta el citado autor- la mayor descoordinación -y añadiría yo tiempo-que comportará la doble sustanciación de decantarnos por la imposición de una sanción administrativa a la persona jurídica y otra penal a la persona física.

8. La segunda, a modo de solución intermedia, consistiría en rescatar las conocidas pero infrautilizadas "consecuencias accesorias del delito" -todavía hoy vigentes-que, en su versión original y con ocasión de la gran reforma operada en 1995, se establecieron en el art. 129 CP. Un instrumento made in Spain cuasi inédito en la praxis judicial ${ }^{133}$ que, con el debido desarrollo de su régimen jurídico y procesal, bien podría haber resultado suficiente para combatir, eficazmente, los distintos factores criminógenos que se vinculan a la empresa en general ${ }^{134}$. $Y$, en especial, el más relevante e indubitado, su

${ }^{133}$ En este punto, resulta especialmente esclarecedor el trabajo elaborado por SILVA SÁNCHEZ, "La aplicación judicial de las consecuencias accesorias para las empresas", InDret 2/2006, 15 pp., en que se da cuenta del recorrido judicial desde 1995 hasta 2006 de estas medidas a medio camino entre las penas y las medidas de seguridad. Una -modesta- praxis que, a buen seguro, debería servirnos de termómetro para medir la futura aplicación de la flamante y moderna RPPJ cuyo resultado -como casi siempre sucede- vendrá determinado por el papel que, finalmente, asuma el Ministerio Fiscal, así como la empatía que esta institución, ajena a nuestra cultura germánico-romana, suscite entre los miembros del Poder Judicial. ${ }^{134}$ Así lo han defendido, entre otros, FEIJOO SÁNCHEZ, Sanciones para empresas..., p. 198, para quien la adecuada explotación doctrinal y legislativa de las consecuencias accesorias, además de "enterrar-aunque seguro que no lo hará- la tradicional discusión sobre la responsabilidad penal de las personas jurídicas", casaría con "las exigencias de los postulados dogmáticos-garantistas-clásicos y las modernas exigencias 
instrumentalización por las personas físicas que las gestionan con la finalidad última de dificultar la precoz detección, persecución y enjuiciamiento de aquellos delitos cometidos en su seno ${ }^{135}$. Y ello tanto si, puntualmente, son perpetrados en beneficio o provecho de la propia entidad (por ejemplo una reducción de los costes que comportaría la efectiva implementación de medidas encaminadas a eliminar o reducir los riesgos laborales para con sus empleados). O, como sucede más frecuentemente, lo son en perjuicio grave de los intereses patrimoniales y personales de quienes con ella interactúan ad intram (por ejemplo, respectivamente, de los socios o accionistas o la propia seguridad laboral -y también económica- de los trabajadores) o bien ad extram (los potenciales y reales consumidores, pequeños y grandes inversores, proveedores o acreedores de la sociedad en cuestión) ${ }^{136}$.

utilitaristas o pragmáticas"; FERNÁNDEZ TERUELO, Instituciones..., p. 118, quien las califica de "idea brillante y original (...) pero, mal configurada y por ello apenas utilizada", indicando como principales defectos técnico-jurídicos: a) la parca definición de sus presupuestos aplicativos y criterios de imposición; b) su limitación a unos pocos delitos entre los que no se encuentran los socioeconómicos; c) la imprecisión del contenido concreto de las medidas previstas; o d) la omisión expresa del criterio de conexión entre el delito cometido por la persona física y la medida impuesta a la persona jurídica; Mir Puig, "Una tercera vía en materia de responsabilidad penal de las personas jurídicas", RECPC (1) 2004, pp. 4-6, quien también dio cuenta del, digamos, divorcio que dista entre las potencialidades atribuidas a este instrumento en la lucha contra la delincuencia empresarial y los defectos de ejecución legal que habrían lastrado, significativamente, la eficacia preventiva que se le presuponía.

${ }^{135}$ En este sentido, se pronunció en su día, entre otros, FEIJOO SÁNCHEZ, Sanciones para empresas..., pp. 154-155, quien concluyó "considerar las consecuencias del artículo 129 como medidas de seguridad (o, si se quiere, consecuencias de naturaleza similar) encaminadas a luchar contra la peligrosidad objetiva de la empresa permite una lucha político-criminalmente eficaz contra la utilización de empresas o estructuras societarias para burlar la persecución penal o para eludir responsabilidades penales o bien como instrumentos delictivos". Una opinión compartida, entre otros, por FERNÁNDEZ TERUELO, Instituciones..., pp. 118-119, para quien, debidamente desarrollada, se erigiría en una fórmula "no sólo más respetuosa con los principios garantistas esenciales de nuestro modelo dogmático, sino también probablemente más eficaz", haciendo así innecesaria la ficción representada por la RPPJ; y PAREDES CASTAÑÓN, "La responsabilidad penal por productos defectuosos: problemática político-criminal y reflexiones de lege ferenda", en Derecho Penal de la Empresa, CORCOY BIDASOLO (dir.), Ed. Universidad Pública de Navarra, Pamplona, 2002, p. 431, para quien se trataría de un "instrumento de inapreciable valor para enfrentarse a las organizaciones delictivas, especialmente a las empresariales", eso sí, concluye el citado autor, siempre y cuando "dicha regulación más adecuada (...) estuviese acompañada de una dotación de medios a los órganos jurisdiccionales, al Ministerio Fiscal, a las fuerzas de seguridad, etc., que permitiese luego aplicarla". ${ }^{136}$ Insiste -con razón-CORCOY BIDASOLO, “Algunas cuestiones político-criminales...”, pp. 165-166, en la necesidad de que las sanciones a imponer a las propias personas jurídicas no perjudiquen a terceros ajenos a la gestión material de la misma (trabajadores, proveedores, clientes, socios minoritarios...). De hecho, a su juicio, la introducción de la RPPJ, siquiera cumulativamente a la de la persona física, habría disminuido la "eficacia preventiva de la intervención penal", precisamente, "porque si se trata de una empresa-persona jurídica real y activa, las consecuencias de la intervención penal las sufren los proveedores, trabajadores y clientes, e incluso, en determinados supuestos, los socios. En el supuesto de tratarse de una sociedad "pantalla", sencillamente habrá desaparecido cuando se pretenda intervenir penalmente". 
9. Hasta cierto punto, resulta lógico el pobre bagaje judicial que han ofrecido las consecuencias accesorias, pudiendo ello responder, como señaló en su día -muy atinadamente- SiLva SÁNCHEZ a la confluencia de diversas causas ${ }^{137}$. En primer lugar, el desconocimiento y carácter ajeno de estas sanciones penales a la cultura jurídica de unos Jueces y Magistrados acostumbrados a "sentar en el banquillo" a personas físicas y donde la "participación" de las jurídicas queda relegada a su condición de demandadas subsidiarias con ocasión del establecimiento de la responsabilidad civil ex delicto (art. $120.2^{\circ}, 3^{\circ}$ y $\left.4^{\circ} \mathrm{CP}\right)^{138}$. Un "cambio cultural" que difícilmente podía producirse dada la parquedad y deficiente redacción del art. $129 \mathrm{CP}$ y la orfandad procesal sobre la que proyectar su canalización en el procedimiento, siendo éste el segundo gran factor explicativo de su silente aplicación ${ }^{139}$. Esta inexistencia de criterios legales y procesales precisos sobre los que fundamentar y articular su imposición, unido a la propia gravedad de las sanciones legalmente previstas (clausura temporal o definitiva; disolución; restricciones en la contratación pública; intervención de la sociedad,...), pudo motivar la asunción de una restrictiva y prudente interpretación tanto en su aplicación en el plenario, como, particularmente, en aquellos escasos casos en que se suscitó su cautelar imposición en instrucción ${ }^{140}$.

${ }^{137}$ Comparto el certero diagnóstico formulado por SILVA SÁNCHEZ, InDret 2/2006, pp. 10-12. Un peligro cierto igualmente advertido por FEIJOO SÁNCHEZ, Sanciones para empresas..., p. 210, quien concluyó "Nuestros órganos judiciales no están precisamente preparados para esas tareas y siempre resulta difícil la aplicación de una nueva consecuencia jurídico-penal anteriormente inexistente por la propia inercia de la actividad forense".

${ }^{138}$ Como señala con acierto SILVA SÁNCHEZ, InDret 2/2006, pp. 11-12, “una ley que obvia la dimensión procesal de la imposición de consecuencias 'sancionatorias' a las personas jurídicas en la jurisdicción penal no puede, desde luego, producir un cambio cultural como el supuestamente pretendido". En esta línea, FEIJOO SÁNCHEZ, Sanciones para empresas..., p. 216, ya hizo hincapié en el hecho de que, más allá de los efectos simbólicos, su eficacia práctica estaba condicionada al desarrollo de "un Derecho Procesal Penal pensado para los procedimientos de los que se pueda derivar consecuencias distintas de las civiles para personas jurídicas".

${ }^{139}$ Nuestro díscolo legislador, además de olvidar-en demasiadas ocasiones-la preceptiva modificación del cauce procesal, nunca incluye una memoria presupuestaria que permita cuantificar los costes económicos que comportará la reforma penal de traducirse ello en un presumible aumento de los recursos policiales, fiscales y judiciales destinados a la cumplida detección, persecución y enjuiciamiento de los nuevos tipos incorporados. Y, no menos importante, los gastos que la misma reportará en términos penitenciarios (contratación de más funcionarios o construcción o ampliación de nuevos centros...) de haber optado por un endurecimiento de las penas - una práctica, desgraciadamente, muy habitual- que potencialmente se plasmará en ingresos efectivos en prisión y un incremento de la población reclusa que, bueno sería, requerirá la oportuna previsión contable. Sin embargo, el capítulo de omisiones, se completaría con el nulo esfuerzo desplegado por el Ministerio de Justicia en la valoración ex post del impacto que la ley penal de turno tuvo -o no- en la realidad criminológica sobre la que se pretendía incidir.

${ }^{140}$ Como el propio SILVA SÁNCHEZ, puso, meridianamente, de manifiesto en un anterior trabajo, Los delitos contra el medio ambiente, Ed. Tirant, Valencia, 1999, p. 145, en esta restrictiva aplicación de las consecuencias accesorias, tanto si son decretadas cautelarmente como en la Sentencia, pesarán, de forma especial, las graves -y añadiría yo en muchos casos irreparables- "repercusiones de indole mercantil y 


\section{Un recurso eficaz no especialmente complicado de canalizar en el proceso penal} dado que, materialmente y salvando las distancias, se configurarían como una suerte de inhabilitación especial aplicable a entes colectivos. O si se prefiere, una especie de comiso en la medida en que está específicamente destinado a combatir la utilización de la persona jurídica como instrumento o efecto de delito ${ }^{141}$. Claro está, ello habría requerido un esfuerzo del legislador a la hora de concretar el estatuto procesal de un ente colectivo que, si bien no estaría formalmente imputado en el proceso penal al no cometer delito alguno $^{142}$, no puede obviarse la negativa repercusión que la imposición

laboral, en cuanto a la disolución judicial y la cesación de las relaciones laborales", siendo precisamente estas razones las que disuadan a los Jueces y Tribunales en el momento de acordar su hipotética imposición. ${ }^{141}$ En esta línea se ha expresado, entre otros, MIR PUIG, "Una tercera vía en materia de responsabilidad penal de las personas jurídicas", RECPC (1) 2004, pp. 3-4, quien si bien rechaza la naturaleza punitiva de las consecuencias accesorias y el comiso, concluye que ambas instituciones responden a una parecida finalidad "privar del instrumento peligroso que representa la persona jurídica o la empresa, o controlar su uso". Si bien la concreción de su naturaleza jurídica dista de ser una cuestión pacífica (desde su consideración de "medidas preventivas extra-penales con finalidades asegurativas o coercitivas, "medidas de seguridad aplicables a objetos peligrosos"; "auténticas penas aplicables a la persona jurídica") a mi juicio, existen elementos suficientes que avalarían su $A D N$ punitivo-sancionador. No en vano, como ha destacado FEIJOO SÁNCHEZ, Sanciones para empresas..., pp. 144 y ss., -siguiendo en este punto a ZUGALDÍA ESPINAR-, "no dejan de ser "extrañas" sanciones administrativas aquéllas que están previstas por el Código Penal, son impuestas por un órgano jurisdiccional penal como consecuencia de una infracción penal, en el curso de un procedimiento penal y están orientadas a prevenir la continuidad delictiva y los efectos de la misma. Se trata, pues, de consecuencias que pertenecen al Derecho penal'. Esta naturaleza penal explicaría, precisamente, la cabal exigencia del cumplimiento de los principios y garantías que toda medida limitadora de derechos conlleva. En especial, la necesaria proporcionalidad entre esta-grave-sanción y la finalidad que justifica su imposición, así como todas las garantías derivadas del derecho de defensa que asiste a todo aquél cuyos intereses podrían resultar afectados de admitirse alguna de las consecuencias previstas en el catálogo del art. 129 en su originaria configuración (pensemos, por ejemplo, en los accionistas cuya empresa se clausura temporal o definitivamente, se interviene judicialmente o disuelve la persona jurídica que está en su base).

${ }^{142}$ Como señaló -con razón- FEIJOO SÁNCHEZ, Sanciones para empresas..., p. 215, nota. 28, "no se debe olvidar que la empresa no es imputada directamente por la comisión del delito, sino que su posición procesal es accesoria o secundaria en el procedimiento que se sigue contra la persona física, que es la que determina el tipo de procedimiento (con las correspondientes garantías) y el órgano competente". De ahí que, salvando las necesarias distancias, el citado autor equipare, parcialmente, la situación de la empresa a la ocupada por el responsable civil subsidiario a las que el Tribunal Supremo, en una generosa interpretación, ha otorgado amplias posibilidades de intervención en el proceso penal, cuando, además y a diferencia de esta última, no se trata de la imposición de una obligación de reparar -civilmente- sino de responder de una consecuencia de naturaleza penal. Como advierte el citado autor-citando a SALAS CARCELLER, "Consecuencias accesorias", en Penas y medidas de seguridad en el nuevo Código Penal-, POZA CISNERO (dir.), CDJ (24) Madrid, 1996, p. 344, el requisito de la preceptiva "audiencia previa" previsto en la redacción original del art. $129 \mathrm{CP}$-ahora eliminado- garantiza el traslado de las actuaciones a los titulares o representantes " a fin de que puedan comparecer en la causa con la correspondiente representación procesal, formulando escrito en defensa de su posición jurídica acerca de los hechos que se discuten y la procedencia de la medida o medidas solicitadas, asistiendo a juicio como una parte más - asimilada a la figura del tercero responsable civil-con posibilidades de recurrir la resolución que imponga tales consecuencias" (p. 214, nota. 27). 
de una medida tan gravosa tendrá sobre los accionistas o propietarios de las participaciones sociales y los trabajadores y acreedores de la misma.

11. La última y, sin lugar a dudas, maximalista solución fue la adoptada por el legislador en la modificación perpetrada en la LO 5/2010, en que se decantó por la incorporación de la RPPJ (art. 31 bis), dando así cumplida respuesta a un -supuesto- mandato comunitario o internacional ${ }^{143}$. Una responsabilidad que, como ha puesto de relieve la doctrina especializada, se ha vehiculado por una doble vía. Por un lado, la imputación de aquellos delitos "cometidos en nombre o por cuenta de las mismas, y en su provecho" (art. 31.1. bis párr. $1^{\circ}$ ) por las personas físicas que ostentan el poder de representación en su seno. Y por otro lado, respondiendo de aquellos ilícitos cometidos por los empleados -también en favor o en provecho de la empresa-cuya imputación se ha fundamentado en el incumplimiento de un deber de vigilancia ("debido control") impuesto a la misma (art. 31.1. bis párr. $\left.2^{\circ}\right)^{144}$. Yendo por delante que se trata de una cuestión

${ }^{143}$ Hago referencia a un supuesto mandato europeo o supracomunitario porque las distintas Decisiones Marco y Directivas comunitarias obligaban a sancionar a las propias personas jurídicas pero no, necesariamente, recurriendo a medidas de naturaleza penal. Se trata de una fácil coartada a la que, de un tiempo a esta parte y a modo de argumento de autoridad, recurre usualmente nuestro legislador nacional bloqueando así todo posible debate sobre la racionalidad y oportunidad político-criminal de la decisión en cuestión. En este sentido, se han pronunciado reputados especialistas en la materia, entre otros, FERNÁNDEZ TERUELO, Instituciones..., p. 113, para quien “(...) el análisis detallado de los textos nos permite comprobar que la imposición de penas era sólo una alternativa de entre las posibles"; GÓMEZ MARTÍN, "Falsa alarma. O sobre por qué la Ley Orgánica 5/2010 no deroga el principio societas delinquere non potest", en Garantías constitucionales y Derecho penal europeo, MIR PUIG / CORCOY BIDASOLO (dirs.), GÓMEZ MARTÍN (coord.), Ed. Marcial Pons, Madrid, 2012, p. 359, quien sin paliativos sostiene que "los instrumentos de Derecho comunitario que instan a los Estados miembros a adoptar medidas en la lucha contra la criminalidad cometida desde la persona jurídica ni imponen que tales medidas sean de naturaleza jurídico-penal, ni obligan, en modo alguno, a la instauración de uno u otro modelo de responsabilidad"; ORTIZ DE URBINA GIMENO, "Sanciones penales...”, p. 277, quien con la contundencia que le caracteriza concluye "la explicación de la introducción de la RPPJ ofrecida por el legislador español a la ciudadanía no responde a la realidad. La inclusión de la responsabilidad penal de las personas jurídicas en España no es una obligación internacional de ningún tipo, sino una decisión político-criminal ordinaria que debería haberse justificado conforme a su adecuación en tales términos".

${ }^{144}$ Vid., por todos, GÓMEZ MARTÍN, "Falsa alarma...", pp. 348-352, en cuyo trabajo el lector podrá encontrar una cumplida y completa relación bibliográfica -hasta el 2012- acerca de una temática que, como apunta dicho autor, ha despertado un inusitado - a la par que comprensible- interés en la doctrina nacional y comparada (p. 333, nota. 2). Con posterioridad, merecen citarse también por la importancia de sus autores, los artículos contenidos en cuatro colectáneas que, pese a centrarse en los programas de cumplimiento penal como instrumento de prevención, detección y reacción frente a los delitos cometidos en la órbita de la empresa, tienen a la responsabilidad penal de las personas jurídicas como cuestión de fondo, Compliance y teoría del Derecho penal, KUHLEN / MONTIEL / ORTIZ DE URBINA (eds.), Ed. Marcial Pons, Madrid, 2013; El derecho penal en la era compliance, ARROYO ZAPATERO (dir.), Ed. Tirant, Valencia, 2013; Criminalidad de empresa y compliance. Prevención y reacciones corporativas, SILVA SÁNCHEZ (dir.), Ed. Atelier, Barcelona, 2013; y Responsabilidad de la Empresa y Compliance. Programas de prevención, detección y reacción penal, MIR / CORCOY / GÓMEZ (dirs.), HORTAL / VALIENTE (coords.), Eds. Edisofer/Bdef, Madrid-Montevideo, 2014. 
doctrinalmente muy controvertida, el legislador nacional habría acogido un sistema mixto de "heterorresponsabilidad" o "por hecho ajeno" y de "autorresponsabilidad" o "responsabilidad por hecho propio" en la medida en que habría combinado -no sabría decir si consciente o inconscientemente- elementos propios de uno y otro sistema de imputación a la persona jurídica ${ }^{145}$.

12. Ahora bien, al margen del reto dogmático -y procesal- que la introducción de la RPPJ conlleva para la clásica teoría general del delito y los principios político-criminales sobre los que se sustenta, lo más paradójico - o no- es que dicha plasmación jurídicopenal podría acabar beneficiando, precisamente, a los delincuentes de cuello blanco. En efecto, es cierto que, en ocasiones, identificar al verdadero responsable -persona física- que ha cometido el delito en el marco de una estructura organizativa compleja como la empresa puede ser todo menos sencillo. Pero también lo es que la RPPJ podría desincentivar la búsqueda de la auténtica persona física responsable de la comisión del delito porque a quienes tienen la obligación de perseguirlo les podría resultar más fácil conformarse con una realidad tangible y fácilmente identificable como la representada por la propia persona jurídica ${ }^{146}$. Quizás la solución entonces no pase por la

${ }^{145}$ Como ha puesto de relieve, entre otros, GÓMEZ MARTÍN, en Comentarios al Código Penal. Reforma LO 1/2015 y LO 2/2015, CORCOY BIDASOLO/MIR PUIG (dirs.)/VERA SÁNCHEZ (coord.), 2a ed, Ed. Tirant, Valencia, 2015, pp. 185-186, se habría consagrado un modelo de heterorresponsabilidad en la medida en la empresa respondería por el delito cometido por una persona física a ella vinculada (directivo o empleado) que lo perpetraría por cuenta o en provecho de la primera. Sin embargo -continúa el autorotro sector doctrinal defiende la existencia de indicios que podrían avalar el establecimiento de un sistema de autorresponsabilidad o imputación a la persona jurídica por hecho propio. En primer lugar, el hecho de que la persona jurídica también responda en los casos de no individualización de la persona física responsable o haya resultado imposible dirigir el procedimiento penal contra ella. Y, en segundo lugar, la no comunicabilidad a la persona jurídica de las circunstancias que afecten a la culpabilidad de la persona física o agraven su responsabilidad. Para una completa y detallada descripción de los distintos sistema de imputación a la persona jurídica, así como sus ventajas e inconvenientes y la imprescindible referencia a los modelos de derecho comparado, resulta de lo más recomendable el magnífico trabajo realizado por el que, a buen seguro, constituye uno de los mayores especialistas en materia de RPPJ en España, NIETO MARTÍN, La responsabilidad penal..., pp. 85-214. Una sucinta pero igualmente esclarecedora descripción de los tres sistemas ("heterorresponsabilidad"; "autorresponsabilidad" y "mixto") puede encontrarse en el artículo elaborado por DÍEZ RIPOLLÉS, InDret, 1/2012, pp. 6-11.

${ }^{146}$ Así lo han puesto de manifiesto, entre otros, FEIJOO SÁNCHEZ, Sanciones para empresas..., p. 202 y 208-209, quien ya identificó, respectivamente, como "el auténtico problema político-criminal que se puede constatar en la actualidad es que no están respondiendo los verdaderos responsables -los que tienen auténticamente un dominio normativo del hecho-de los hechos delictivos cometidos en beneficio o en el seno de entidades colectivas $u$ organizaciones complejas -advirtiendo que-La punición de personas jurídicas no sólo no va a mejorar sino que va a empeorar dicha situación de impunidad" (p. 202) -precisa más adelante- "para las personas físicas alli donde puede responder una empresa o sociedad, lo cual conllevaría unos serios déficits preventivos" -y concluye- "lesionándose los sentimientos de justicia de la población, que percibirá que en determinados ámbitos no son castigados los auténticos 
introducción de un cuerpo extraño a nuestra cultura jurídico-penal como es la RPPJ, sino, contrariamente, por la mejora de los sistemas de detección y persecución delictivo, así como el perfeccionamiento de las reglas de imputación que permitan fundamentar la responsabilidad penal de quien, efectiva y naturalmente, ostenta capacidad de acción y culpabilidad para cometer delitos ${ }^{147}$.

\section{En un claro paralelismo con lo sucedido en el ámbito de la seguridad en el trabajo,} estoy convencido de que la asunción por el empresariado de una cultura en materia de prevención de riesgos penales, coadyuvará a la evitación de hechos delictivos en su

culpables a diferencia de lo que sucede en otros supuestos más simples de delincuencia" (pp. 208-209); CORCOY BIDASOLO, “Algunas cuestiones político-criminales...”, p. 191, para quien lo único evidente que suscita la introducción de la RPPJ "es que no responda nadie (las personas jurídicas "desaparecen" más fácilmente que las fisicas) o, en su caso, exclusivamente quienes no son responsables: trabajadores, proveedores, clientes, consumidores y socios de la persona jurídica-empresa imputada, no vinculados a la gestión"; FERNÁNDEZ TERUELO, Instituciones..., p. 117, para quien "el establecimiento de un modelo de responsabilidad de los entes sociales puede contribuir a relajar los esfuerzos por localizar al autor (persona fisica) del hecho delictivo e imputarle el delito", pronosticando que ello en la práctica podría traducirse en la condena única de la propia sociedad; GÓMEZ MARTÍN, "Falsa alarma...", p. 357, quien también ha señalado como la RPPJ, además de constituir una solución claramente desproporcionada, "bien podría acabar provocando una cierta relajación en la persecución de quien realmente habría cometido el delito, esto es, la persona fisica, al grito de "siempre nos quedará la empresa". Un peligro que no ha sido negado, sino todo lo contrario, admitido por quienes como NIETO MARTÍN, La responsabilidad penal..., p. 48, nota. 85 , se han mostrado abiertamente favorables a la acumulativa previsión de la RPPJ. En efecto, dicho autor se hace eco de la experiencia norteamericana "donde gracias a la responsabilidad penal de las personas jurídicas la individual sólo aparece en casos excepcionales”, trayendo a colación el dato según el cual "en el $48 \%$ de los procesos contra personas jurídicas no se dirigen contra ningún responsable individual". Un porcentaje que califica de "alarmante" y que "crea un sistema de privilegio para los delitos económicos" donde, adicionalmente, "se degrada el significado social de la -responsabilidad-penal".

${ }^{147}$ En este sentido se ha pronunciado DÍEZ RIPOLLÉS, InDret, 1/2012, p. 4, quien, tras mostrar su disconformidad con aquéllos que fundamentan la RPPJ en base a las dificultades a la hora de delimitar la responsabilidad individual de las personas físicas que en seno actúan, concluye "Al igual que no hacemos responder a una persona fisica para identificar, o precisar mejor, la responsabilidad de otra. Los problemas de verificación de la responsabilidad individual han de resolverse mejorando los instrumentos para su averiguación". Una idea que igualmente comparten, entre otros, FERNÁNDEZ TERUELO, Instituciones..., p. 117 y 119, quien apela, respectivamente, a la posibilidad de acudir al "expediente del levantamiento del velo" para identificar a las verdaderas personas físicas responsables del delito y a la inclusión de "una buena fórmula de responsabilidad omisiva referida a personas físicas con capacidad de gestión en las sociedades"; CORCOY BIDASOLO, "Algunas cuestiones político-criminales...”, p. 192, quien en la línea del anterior autor, destaca el paradójico desarrollo que en el formalizado derecho mercantil ha experimentado la doctrina del levantamiento del velo y "la responsabilidad del administrador de hecho (con independencia de quien figure como administrador de derecho)"; y GÓMEZ MARTÍN, "Falsa alarma...", p. 357, quien, junto a la mejora de los instrumentos forenses desplegados en la "investigación de los hechos delictivos empresariales", propone la articulación de "criterios de imputación de responsabilidad individual en estructuras organizativas complejas que permitan realizar correctamente aquella función de depuración". 
seno ${ }^{148}$. En efecto, de la misma forma que un adecuado y preciso plan de prevención de riesgos laborales contribuye a reducir la tasa de accidentes de trabajo, la implementación de un completo programa de cumplimiento penal hará lo propio con los delitos que potencialmente pueden cometerse con ocasión de la actividad empresarial ${ }^{149}$. Para ello claro está no sólo resultará imprescindible desarrollar un compliance program que se ajuste a los riesgos penales propios de la sociedad en cuestión (p.e., delitos relacionados con la corrupción por tratarse de una sociedad que mantiene relaciones contractuales permanentes con las Administraciones Públicas), sino también deberá nombrarse un oficial de cumplimiento que, en sintonía con el rol desempeñado por el técnico en prevención de riesgos laborales, vele por su efectiva y cumplida aplicación, en tanto delegado del garante último, esto es, el empresario.

14. Dicho esto, no puedo ni debo dejar pasar la ocasión para denunciar la exclusión del delito contra la seguridad en el trabajo de la órbita de la RPPJ. Una omisión que, como ha puesto de manifiesto LASCURAÍN SÁNCHEZ, resulta doblemente sorprendente ${ }^{150}$. En primer lugar, porque el tipo contenido en el art. $316 \mathrm{CP}$ forma parte del reducido número de ilícitos penales que, en su caso desde 2003, permitían la adopción de las

\footnotetext{
${ }^{148}$ Estoy de acuerdo con NIETO MARTÍN, La responsabilidad penal..., pp. 51-52, en que la RPPJ vendría a complementar "el sistema público de control social individual" por medio de un "sistema interno de la organización de carácter privado", transformándolas "en colaboradoras del sistema policial estatal", pero no cuando niega que ello pueda, simultáneamente, entenderse como "una receta neoliberal privatizadora". Efectivamente, como ha puesto de manifiesto DÍEZ RIPOLLÉS, InDret, 1/2012, p. 5, resulta difícil desvincular dicho planteamiento "de la idea de que los poderes públicos renuncian en parte a ejercer, o perfeccionar, sus tareas preventivas y persecutorias penales, que se trasladan a centros de poder privados". Lo cual, en última instancia, continúa el citado autor, "supone una renuncia en toda regla al carácter público del derecho penal, en acomodación a planteamientos neoliberales". De la misma forma que como ya alertó FEIJOO SÁNCHEZ, Sanciones para empresas..., p. 219, nota. 34, la principal herramienta desplegada para evitar la RPPJ, es decir, el compliance program, respondería "a un modelo neoliberal de organización estatal en el que el Estado renuncia a gran parte de las funciones delegando las mismas en otros actores sociales". ${ }^{149}$ Como ha reconocido en Alemania un reputado especialista en la materia como KUHLEN, "Compliance y Derecho penal en Alemania”, en Responsabilidad de la Empresa y Compliance. Programas de prevención, detección y reacción penal", MIR / CORCOY / GÓMEZ (dirs.), HORTAL / VALIENTE (coords.), Eds. Edisofer/Bdef, Madrid-Montevideo, p. 103, "La orientación a la propia empresa es un planteamiento eficaz para mejorar la observancia de las normas que puede aprovechar el efecto formativo o moldeador que tienen la empresa y su cultura en cada uno de los trabajadores". Un traslado de obligaciones estatales a la esfera de los agentes privados representados por la propia empresa que, a juicio del citado autor, podría erigirse en un incentivo para la implementación de programas de prevención penal y su efectivo cumplimiento con la "expectativa" de que con ello "se prescinda de las sanciones a empresas por parte del Estado o que éstas se reduzcan a las más leves” (p. 107).

${ }^{150} \mathrm{Vid}$., LASCURAÍN SÁNCHEZ, "La prevención del delito contra la seguridad de los trabajadores", en Manual de cumplimiento penal en la empresa, NIETO MARTÍN (dir.), Ed. Tirant, Valencia, 2014, p. 516.
} 
"consecuencias accesorias" 151 . Y, en segundo lugar, porque se trata de uno de los delitos en los que de forma más palmaria se proyecta la racionalidad económica propia de las empresas. Esto es, el incumplimiento de las obligaciones preventivo-laborales se traduce, automáticamente, en una reducción de los costes y, por ende, en una compañía más competitiva frente a aquéllas que, contrariamente, sí las observan. De ahí que, en estrictos términos criminológicos, carezca de sentido su exclusión, ya que la imposición de una sanción a la propia persona jurídica, en principio, debería desincentivar la implementación y/o continuación de una política o cultura empresarial como la descrita.

15. Por último y a modo de conclusión quisiera trasladar una cuádruple consideración. Primero, manifestar mis reservas acerca del hecho de que dicha colaboración privada deba garantizarse, obligatoriamente, a través del negativo incentivo representado por la amenaza de imposición de una pena a la propia persona jurídica ${ }^{152}$. Segundo, no creo que la RPPJ constituya ese remedio milagroso que cual brebaje mágico previene y cura todos los males criminógenos identificados con la empresa en tanto organización más o menos compleja ${ }^{153}$. Pero tampoco estamos ante una suerte de "anatema dogmático" capaz de socavar los frágiles pilares del Derecho penal y el sistema de garantías consustancial a un Estado Social y Democrático de Derecho. De igual forma que, anteriormente, no se tambalearon, cuando diversas razones de orden pragmático y político-criminal, aconsejaron y legitimaron la construcción de un Derecho penal

\footnotetext{
${ }^{151}$ Con un ingenioso juego de palabras, concluye LASCURAÍN SÁNCHEZ, "La prevención del delito...", p. 516, "resulta curioso que esta avanzadilla de la responsabilidad penal de las personas jurídicas acabara en la retaguardia cuando este tipo de responsabililidad se implanta en el año 2010".

${ }^{152}$ Así lo demostraría la propia realidad en Alemania, donde como ha señalado -con razón-ORTIZ DE URBINA GIMENO, "Sanciones penales...", p. 264, no cuentan con la RPPJ y ello no ha impedido el arraigo del compliance. Claro está -y como el propio autor reconoce- en nada ayuda el hecho de que, hasta la fecha, no contemos con datos contrastados acerca del cambio que la RPPJ ha supuesto en el proceder de las empresas y la inexistencia de pronunciamientos judiciales al respecto. Quizás cuando se cumplen 5 años desde su incorporación en 2010, sea el momento de verificar criminológicamente las características de las empresas (dimensiones, sector de actividad en el que operan...) que han implementado programas de cumplimento penal, así como su verdadera eficacia tanto en la prevención de delitos en su seno como en la detección de los ya perpetrados. Y una vez desplegada esta imprescindible tarea criminológica, será cuando estemos en disposición real de determinar en qué medida la plasmación de la RPPJ ha traído consigo un cambio en la cultura preventivo-penal de nuestro tejido empresarial. Como ya denunciara, con carácter general, entre otros, FEIJOO SÁNCHEZ, Sanciones para empresas..., p. 207, "Se presupone la eficacia preventiva de las penas para empresas pero no existe estudio empírico alguno que lo justifique ni se ha desarrollado un modelo preventivo empíricamente plausible sobre cómo las normas pueden influir directamente en las empresas y no indirectamente a través del comportamiento de sus integrantes".

${ }^{153}$ En parecidos términos se pronunció FEIJOO SÁNCHEZ, Sanciones para empresas..., p. 205, para quien "da la impresión de que existe una excesiva confianza en lo que puede aportar un sistema de verdadera punición de entes colectivos como si se tratara de la varita mágica que puede arreglar los problemas que están presentando las formas más modernas de criminalidad".
} 
juvenil o de medidas de seguridad para sujetos inimputables peligrosos que discurría y discurre en paralelo, respectivamente, al derecho penal de adultos o de las personas físicas que actúan en condiciones motivacionales normales. Cuarto, y muy a mi pesar, insistir en lo que constituye una certeza. La RPPJ ha venido para quedarse y ahora la doctrina penal tiene el difícil - a la par que sugerente desafío- de proporcionar a los distintos operadores jurídicos los criterios y reglas de imputación que -en el día a día de su aplicación judicial- permitan fundamentarla, sin violentar en exceso, los principios y garantías propios del Derecho penal -y constitucional-. Asímismo, deberá esforzarse en facilitar las herramientas jurídico-procesales precisas que garanticen el adecuado encaje en las -hipotéticas causas que se acaben incoando-de todas aquellas personas físicas y/o jurídicas cuyos intereses económico-patrimoniales, sin ningún género de dudas, se verán, directa o indirectamente, comprometidos como consecuencia de la acumulativa imputación al ente societario-colectivo ${ }^{154}$.

\section{c) Su incidencia en el-racional-diseño político-criminal del sistema de penas: multa, inhabilitación especial y prisión}

1. Más allá de los -presuntos- beneficios preventivo-represivos aparejados a la propia RPPJ y (re)tomando las coordenadas criminológicas ya descritas, toca ahora preguntarnos por las medidas que, a grandes rasgos, deberían adoptar los poderes públicos para responder más eficazmente a los delitos socioeconómicos. En este punto, a mi juicio, cobran en el plano extra-penal un especial protagonismo la implementación -debidamente monitorizada-de aquellas normas que, en un sentido amplio, ordenan el acceso, la prestación y puntual sanción de quienes realizan tareas directa o indirectamente conectadas al mundo de los negocios en general y al tráfico jurídico-mercantil en particular (notarios, registradores, auditores, abogados,...). Especialmente ilustrativo a los efectos del presente trabajo, resulta lo dispuesto en la Ley 10/2014, de 26 de junio, de ordenación, supervisión y solvencia de las entidades de crédito, en cuyos arts. 24, 25 y 26 se da cuenta, respectivamente, de los requisitos de idoneidad exigidos para aquellos que formen parte de los Consejos de Administración de dichas entidades -aplicables también a los directores generales y asimilados $-{ }^{155}$; los recursos y medios destinados

\footnotetext{
${ }^{154}$ Estoy pensando en los conflictos de intereses que se suscitarán entre los gestores y los auténticos dueños de las empresas, es decir, los accionistas y propietarios de las participaciones sociales. Y también de las graves consecuencias económico-laborales que las sanciones impuestas a las propias personas jurídicas tendrá sobre los trabajadores, proveedores, acreedores, consumidores y clientes.

${ }^{155}$ En el art. 24 se establece una cláusula general de aplicación a estos tres colectivos "reúnan los requisitos de idoneidad necesarios para el ejercicio de su cargo" que se traduce en tres condiciones "poseer reconocida honorabilidad comercial y profesional, tener conocimientos y experiencia adecuados para ejercer sus funciones y estar en disposición de ejercer un buen gobierno de la entidad" cuyo contenido se especifica,
} 
a su supervisión y el régimen de incompatibilidades y limitaciones. Ciertamente, la autoimposición empresarial o la heteroimposición estatal de obligaciones encaminadas a seleccionar -y mantener en su puesto-a personas más "honorables" puede contribuir a elegir a aquellos que poseen un marcado código ético-profesional y un acentuado respeto a los estándares legales.

2. Dado que lo anterior puede ser a todas luces insuficiente, toda política criminal racional que se precie debería girar en torno a dos grandes ejes. Como ya señalé, primero, una meditada selección de los bienes jurídicos protegidos acompañada de una precisa delimitación del riesgo típico en virtud de la que, únicamente, se dote de relevancia jurídico-penal a los comportamientos más gravemente lesivos. Y, acto seguido, el diseño cuidadoso de un sistema de penas que, al tiempo que permite el castigo -proporcional- de los hechos ya perpetrados, prevenga su comisión futura. En este punto, resulta perentoria la neutralización del beneficio económico en tanto principal motivación del delincuente de cuello blanco ${ }^{156}$. Un cometido en el que, además del comiso, debería

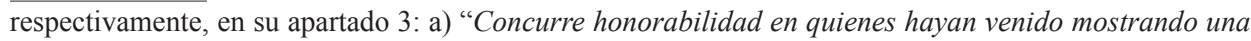
conducta personal, comercial y profesional que no arroje dudas sobre su capacidad para desempeñar una gestión sana y prudente de la entidad. Para valorar la concurrencia de honorabilidad deberá considerarse toda la información disponible, de acuerdo con los parámetros que se determinen reglamentariamente"; b) "Poseen conocimientos y experiencia adecuados para ejercer sus funciones en las entidades de crédito quienes cuenten con formación del nivel y perfil adecuados, en particular en las áreas de banca y servicios financieros, y experiencia práctica derivada de sus anteriores ocupaciones durante periodos de tiempo suficiente"; y c) "Para valorar la capacidad de los miembros del consejo de administración de ejercer un buen gobierno de la entidad se tendrán en cuenta la existencia de potenciales conflictos de interés y la capacidad de dedicar el tiempo suficiente para llevar a cabo las correspondientes funciones". Está claro que, descontextualizada, esta norma puede causar sorpresa por lo básica y obvia que resulta, pero, ex post y visto lo visto, es evidente que ha devenido necesaria al comprobar que, desgraciadamente, en algunos casos los órganos de dirección de las Cajas de Ahorro no siempre fueron presididos por las personas más "honorables, sanas y prudentes"; los consejos de administración y comisiones de control interno no estaban formados por quienes poseían contrastados y suficientes conocimientos en materia financiero-bancaria y que los conflictos de intereses no eran precisamente una excepción en su seno. Es "posible" que si las extintas Cajas de Ahorro hubieran contado en sus consejos de administración y comisiones de control con directivos "honorables, formados y leales" no habría (cuasi)quebrado nuestro sistema financiero y con ello nos habríamos ahorrado un costoso y doloroso rescate público que pagarán, no sólo dichas entidades, sino también y principalmente los ciudadanos de la presente y las generaciones venideras. Al respecto pueden resultar de interés, entre otros, el trabajo elaborado por LÓPEZ JIMÉNEZ / PEREA ORTEGA, "Banqueros sobradamente preparados: algunas reflexiones sobre la idoneidad para el desempeño", DLL (8353) 2014. ${ }^{156}$ En este sentido, se han pronunciado, entre otros, BAUCELLS LLADÓS, CPC (106) 2012, pp. 148 y 159 ; CORCOY BIDASOLO, "Algunas cuestiones político-criminales...", p. 173, para quien "La localización de los bienes del autor debería ir acompañada de su decomiso, lo que tendría una eficacia intimidatoria y, en consecuencia, preventiva, de primer nivel"; FERNÁNDEZ TERUELO, Instituciones..., pp. 155-156, para quien la multa, sobre el papel, puede erigirse en un instrumento idóneo para intimidar a aquellos que se han decantado por la comisión del delito con la finalidad de "incrementar su propio patrimonio a costa de los demás". Si bien, a continuación, matiza -acertadamente- que dicho efecto se conseguirá "siempre y 
jugar un papel central la multa. De hecho, la segunda ya lo cumpliría, por lo menos teóricamente, cuando a mediados de los noventa el legislador la situó en el epicentro de la respuesta punitiva contra la delincuencia socioeconómica ${ }^{157}$. En efecto, aunque en contadas ocasiones, se recurre a la multa como pena única, de forma reiterada, se impone cumulativamente con la prisión, erigiéndose el sistema del días-multa en regla general y la multa proporcional en la excepción ${ }^{158}$. Y, digo en el plano teórico, porque, a buen seguro, el -insuficiente- límite máximo impuesto (400 euros) y los negativos automatismos que afloran en la -siempre relegada- fase de ejecución de la pena han restado fuerza intimidatoria a la multa en general y con respecto a los grandes delincuentes económicos en particular.

3. Ciertamente, el sistema de días-multa habría atemperado las críticas vertidas contra una pena que ha sido tachada - con razón- de desigual debido a la dispar situación económica en que se encontrarían sus distintos destinatarios ${ }^{159}$. Ahora bien, si partimos

cuando la misma sea capaz de incidir sobre el cálculo de eficiencia subjetiva del destinatario, de tal modo que su importe sea superior a los eventuales beneficios que el autor del comportamiento delictivo pudiera esperar como consecuencia del delito".

${ }^{157}$ En este sentido, se han pronunciado, entre otros, CORCOY BIDASOLO, RDF (8) 2012, p. 47, quien la califica de "pena reina en los delitos socioeconómicos" y se muestra muy contundente ante su constatado "fracaso preventivo". Una idea sobre la que ha insistido, más recientemente, cuando, al hilo de la eficacia de los delitos socioeconómicos y de corrupción y las sanciones con las que combatirlos, apostilla "La pena de multa, máxime cuando puede ser muy inferior a la prevista en vía administrativa o a la indemnización que debería hacerse efectiva en vía mercantil o civil, carece de eficacia intimidatoria".

${ }^{158}$ Así lo han puesto de relieve, entre otros, FERNÁNDEZ TERUELO, Instituciones..., pp. 155-163, quien realiza un sucinto pero riguroso estudio acerca de las ventajas e inconvenientes que, en general y en el particular ámbito de la delincuencia económica, plantea el recurso a la pena de multa; BAUCELLS LLADÓS, CPC (106) 2012, pp. 158 y ss., quien sobre una muestra de 39 delitos que comprendería a los urbanísticos, contra el medio ambiente, el mercado y los consumidores, los derechos de los trabajadores y el blanqueo de capitales, concluyó -antes de la reforma operada en la LO 1/2015- lo siguiente: a) en 37 de los 39 se estableció la multa como consecuencia jurídica; b) sólo en 7 de los 39 casos estudiados se previó una multa proporcional correspondiente -en 6 de los supuestos-al triplo del beneficio obtenido; c) únicamente en 2 de los 39 casos examinados se regularon multas proporcionales al beneficio obtenido de resultar ello superior a la cantidad derivada de la pena de días-multa potencialmente imponible (arts. 319.1 y 2 CP); y d) como prueba del suave tratamiento penal dispensado a esta sanción pecuniaria, apunta dicho autor, como en 12 de los 39 ilícitos penales estudiados, se regulan penas de días-multa con un mínimo de 6 meses. Un benévolo tratamiento que ilustra, precisamente, con el mal llamado "fraude de inversores" a cuyos autores se le podrá imponer una pena mínima comprendida entre 360 y 72.000 euros aplicable -añadiría yo-al supuesto más lesivo, esto es, aquél en que el perjuicio efectivamente causado a los sujetos pasivos lo fuera de "notoria gravedad" (p. 160).

${ }^{159}$ Resulta evidente que quienes más tienen tendrán más facilidades para pagarla frente a aquellos que disponen de menos recursos y, por ello, más dificultades para responder a su pago. Como ha puesto de relieve la doctrina, Vid., por todos, MIR PUIG, Derecho penal. Parte General, ( $9^{\mathrm{a}}$ ed.), Ed. Reppertor, Barcelona, 2011, p. 726, la desigualdad constituye de largo el mayor de sus inconvenientes, junto al hecho de que su satisfacción por un tercero podría resultar contrario al principio de personalidad de las penas. 
de la premisa de que la multa tiene como finalidad reducir el nivel de vida del reo, dicho efecto se malogrará respecto a los sujetos activos que dispongan de los mayores patrimonios ${ }^{160}$. Tal sería el caso de los grandes delincuentes de cuello blanco quienes apenas se inmutarían ante las cuantías de unas multas que no limitarán, de forma significativa, su modus vivendi gracias a las grandes reservas que detentan tanto en territorio nacional como en los famosos paraísos fiscales. De ahí que un minoritario sector doctrinal haya propuesto la eliminación del techo legal máximo en el sistema del días-multa actualmente fijado en 360.000 euros $^{161}$. Frente a la presumible y atendible alegación de indeterminación, dichos autores contraargumentan que serán los Jueces y Tribunales los que, además de concretar la duración de la multa sobre la base de la gravedad del hecho y las circunstancias personales del autor, fijen la cuota final a sufragar tomando como único criterio rector la real capacidad económica del reo ${ }^{162}$.

Una desigualdad que, como ha apuntado el citado autor, podría paliarse concediendo al Juez la posibilidad de graduar su cuantía en atención a las capacidades económicas del reo. Si bien, a continuación, reconoce las propias limitaciones a que dicha facultad está sujeta.

${ }^{160}$ Gráficamente en este sentido se ha expresado FERNÁNDEZ TERUELO, Instituciones..., p. 157, quien ha concluido "A partir de determinado nivel de patrimonio (en el que se sitúa casi por definición buena parte de los delincuentes económicos) las multas, aun siendo muy elevadas, pueden carecer de contenido real aflictivo en la medida en que no suelen ser capaces de reducir el nivel de vida del condenado". En parecidos términos, se pronunciaron con anterioridad, entre otros, PAREDES CASTAÑÓN, "La responsabilidad penal por productos...", p. 430, quien concluyó "Es evidente que la pena pecuniaria presenta serias objeciones, en tanto que resulta poco disuasoria frente a un delincuente que casi siempre dispone de elevada capacidad económica y la posibilidad de repercutir, de hecho, el coste a terceros".

${ }^{161}$ Así lo han manifestado, entre otros, BAUCELLS LLADÓS, CPC (106) 2012, p. 159; FERNÁNDEZ TERUELO, Instituciones..., p. 157 y antes que ellos Gracia MARTín, en Lecciones de consecuencias jurídicas del delito, (Gracia Martín, coord.), Ed. Tirant, Valencia, 1998, p. 146. No comparto la propuesta defendida por estos autores, fundamentalmente, porque es posible dotar de una mayor eficacia al sistema de días-multa sin quebrantar el principio de legalidad. Me explico. Frente a la supresión del límite superior con el insoportable riesgo de indeterminación que ello conlleva, entiendo más respetuoso -a la par que eficazoptar por la elevación de la cuantía actualmente establecida en $400 €$. Una cifra que se me antoja del todo insuficiente cuando de grandes delincuentes socioeconómicos se trata y que bien podría incrementarse hasta los $5.000 €$. Con ello, además de equipararla a la fijada para las personas jurídicas (art. $50.4 \mathrm{CP}$ ), haríamos posible la máxima de que "el delito nunca debe ser económicamente rentable para nadie", evitaríamos caer en la tentación de recurrir a la multa proporcional y velaríamos por una más justa conversión de activarse -la no menos conflictiva- responsabilidad personal subsidiaria por impago de multa. Me adhiero así a la propuesta en su día formulada por el GEPC y a los argumentos aducidos en pro del aumento del límite máximo (6.000 €), Una propuesta alternativa al sistema de penas y su ejecución, y a las medidas cautelares personales, Ed. GEPC (8) 2005, p. 46: "El límite económico máximo debe ser elevado, para poder adaptarlo a los casos de sujetos con grandes fortunas, especialmente en supuestos en los que quiere atenderse de forma especial al beneficio económico que el delito concreto ha reportado (incluso aunque el número de días multa impuestos no sea muy extenso). De esta forma, se convierte en innecesaria la multa proporcional, ya que la finalidad actualmente establecida para esta última de reflejar "el valor del objeto del delito o el beneficio reportado" puede conseguirse con el sistema de días multa. Además, este último sistema permite una transformación más igualitaria en la responsabilidad personal subsidiaria". ${ }^{162}$ En este sentido, se ha expresado BAUCELLS LLADÓS, CPC (106) 2012, p. 159, quien hace suyo el argumento formulado en su día por GRACIA MARTÍN. 
4. Ahora bien como he adelantado, el verdadero caballo de batalla en pro de la eficacia preventivo-intimidatoria de la multa no se concentraría-exclusivamente- en su marco normativo, sino, muy especialmente, en las dificultades y malas prácticas internalizadas en la investigación judicial de la verdadera situación económico-financiera del condenado $^{163}$. Es cierto que este proceso de acreditación entraña una cierta complejidad, pero también lo es que son muchos los automatismos con los que se opera en la Administración de Justicia ${ }^{164}$. Un proceder en el que ha jugado un significativo papel

${ }^{163}$ Así lo han puesto de relieve, recientemente, BAUCELLS LLADÓS, CPC (106) 2012,p. 160-161, para quien el principal problema de la multa radicaría en la inadecuada "organización de la Administración de Justicia", una situación que estaría motivada, no sólo por una falta de recursos materiales, sino también por la omisión de las preceptivas reformas procesales que la incorporación y desarrollo de esta pena habría requerido; FERNÁNDEZ TERUELO, Instituciones..., pp. 159-163, quien también sostiene como las mayores dificultades en la determinación de la real capacidad económica del reo en general y del-gran-delincuente económico en particular habrían mermado la eficacia intimidatoria de la multa. A su juicio, tres serían los factores que habrían favorecido dicha merma: a) las propias limitaciones del criterio legalmente establecido en el art. 50.5 CP ("teniendo en cuenta para ello exclusivamente la situación económica del reo, deducida de su patrimonio, ingresos, obligaciones y cargas familiares y demás circunstancias personales del mismo"; b) la existencia de múltiples formas de ocultamiento patrimonial cuyo grado de perfeccionamiento es inversamente proporcional a la menor "entidad" del delincuente económico; y c) los por él denominados "hábitos judiciales" y "actitud de los tribunales" entre los que destaca la falta de motivación de los criterios utilizados por el juzgador en la concreción de la cuota diaria impuesta o el recurso a la imposición en su grado mínimo como medio para evitar las apelaciones. En la misma línea, se pronunciaron con anterioridad a sendos autores, entre otros, LANDROVE DÍAZ, JpD (31) 1998, pp. 38-39, quien, al hilo de la sobreutilización de la multa en el Código Penal del 95 como forma de combatir la delincuencia económica y no sin cierta dosis de ironía, concluyó "bajo una u otra fisonomía -en referencia a la fórmula del días-multa o la proporcional-su ejecución resulta siempre problemática para utilizar un eufemismo. Quizás quienes defienden la idoneidad de este tipo de sanciones al respecto escriban en países en los que-efectivamente- las multas se pagan"; o CARDENAL MONTRAVETA, en Comentarios al Código Penal. Reforma LO 1/2015 y LO 2/2015, CORCOY BIDASOLO/MIR PUIG (dirs.)/VERA SÁNCHEZ (coord.), 2 ${ }^{\mathrm{a}}$ ed, Ed. Tirant, Valencia, 2015, p. 239, quien también ha puesto de manifiesto como la determinación del importe de la cuota "requiere la oportuna investigación, algo que en la práctica no suele realizarse, o no de forma satisfactoria". Por su parte, BAJO FERNÁNDEZ, CPC (5) 1978, p. 28, ya se hizo eco a finales de los 70 de las principales críticas que, tradicionalmente, se han dirigido a la multa como, por ejemplo, la posibilidad de "capitalizar la infracción o de hacer cargar el importe sobre el capitulo de costo o el precio de venta". ${ }^{164}$ A tales automatismos se han referido autores como BAUCELLS LLADÓS, CPC (106) 2012, p. 161, quien ha denunciado el recurso a la nómina del acusado como único criterio sobre el que deducir su capacidad económica en la concreción de la cuota impuesta o el proceder observado en algunas Audiencias Provinciales que se valen del $1 \%$ del salario mensual como baremo exclusivo en la cuantificación de la cuota diaria; y FERNÁNDEZ TERUELO, Instituciones..., p. 161, quien, junto a los déficits de motivación de que adolecen las Sentencias en la fundamentación de la cuota finalmente fijada y la imposición de la cuantía mínima cual "escudo antirrecursos", se muestra especialmente crítico con los "indicios de aproximación" que define como "imprecisas circunstancias personales de carácter objetivo" de la que se sirve el Juez o Tribunal para (mal) deducir la capacidad económica del reo. Así, entre otros, enumera la profesión u oficio que ostenta; el modo de vestir o la forma de expresarse o la comparecencia en juicio con un abogado de libre designación. Para un estudio más detallado de las dificultades que comporta la acreditación judicial de esta capacidad económica, recomiendo el artículo elaborado por el procesalista CACHÓN CADENAS, 
el Tribunal Supremo con su bienintencionada y garantista doctrina que, lejos de solucionar materialmente el problema, sólo ha contribuido a allanar formalmente el camino a la-mal- llamada jurisprudencia menor ${ }^{165}$. Por otra parte, calificaría ya de modestos los esfuerzos y recursos judiciales destinados a la averiguación de la capacidad económica del reo cuando de los más convencionales delitos se trata. Unos medios que, ni decir tiene, resultarán absolutamente insuficientes al acometer la ingente tarea que su indagación supone en los supuestos de condenados por delitos económicos de notable envergadura ${ }^{166}$. La explicación una y simple. Estos últimos, a diferencia de los anteriores, gozan de un mayor grado de conocimientos y sobrados recursos disponibles de corte jurídico y financiero (propios o contratados) para la óptima y eficaz ocultación

\footnotetext{
"La pena de días multa: el difícil juicio sobre la capacidad económica del acusado", en Problemas actuales de la justicia penal: los juicios paralelos, la protección de los testigos, la imparcialidad de los jueces, la criminalidad organizada, los juicios rápidos, la pena de multa, PICÓ I JUNOY (coord.), Ed. Bosch, Barcelona, 2001, pp. 173-222.

${ }^{165}$ En efecto, el Alto Tribunal ha señalado que la concreción de un determinado importe sin el previo análisis de la situación económica del reo conculcaría el derecho a la tutela judicial efectiva (art. 24.1 CE), por cuanto este proceder limita las posibilidades de recurso al desconocerse las razones que han conducido al juzgador a fijar uno cuota en detrimento de otra. De omitirse dicha preceptiva motivación, concluye deberá optarse por la imposición de la mínima cuota posible en aplicación del principio in dubio pro reo que suele situarse en la praxis judicial en la franja de los 6 euros, reservándose la cuantía mínima, esto es, los 2 euros a los casos de acreditada indigencia (Así viene pronunciándose desde la STS 1377/2001, 11-07, RJ. 2001\5961, FJ. 5 , Pte. Conde-Pumpido Tourón, resolución fielmente citada por las dictadas con posterioridad, entre otras muchas, la STS 17/2014, 28-01, RJ. 2013\7718, FJ. $10^{\circ}$, Pte. Berdugo y Gómez de la Torre). A mayor abundamiento, el propio Tribunal Supremo ha abierto la puerta a esta suerte de "dilución motivadora" operada por la jurisprudencia menor cuando, de forma constante, mantiene que los juzgadores no están obligados a "efectuar una inquisición exhaustiva de todos los factores directos e indirectos que puedan afectar a las disponibilidades económicas del acusado, lo que resulta imposible y es, además, desproporcionado, sino únicamente deben tomar en consideración aquellos datos esenciales que permitan efectuar una razonable ponderación de la cuantía proporcionada de la multa que haya de imponerse" (Un párrafo originariamente contenido en la STS 175/2001, 12-02, RJ. 2001 280, Pte. CondePumpido Tourón, FJ. $6^{\circ}$ y que es reproducido, automáticamente, en las posteriores, entre otras muchas, la STS 201/2014, 14-03, RJ. 2014\2118, FJ 4º, Pte. Colmenero Menéndez de Luarca). Como ha puesto de relieve muy acertadamente FERNÁNDEZ TERUELO, Instituciones..., p. 161, esta garantista doctrina del Supremo no se ha traducido en un mayor esfuerzo de nuestros juzgadores en pro de la fehaciente constatación de la concreta capacidad económica disponible por el reo, sino,-lógicamente diría yo-, ha traído consigo dos rechazables prácticas judiciales: a) la imposición de la cuantía mínima como forma de elusión de la obligada motivación y la simultánea desactivación del potencial recurso; y b) un desplazamiento en exclusiva de la labor investigadora del juzgador a la acusación particular, en los casos, claro está, en que se ha personado en el proceso (p. 159 y 162) y en cuya ausencia -añadiría-no ha sido suplida por el Ministerio Público pese a su doble condición de defensor de la "legalidad" y del interés general.

${ }^{166}$ En este sentido, destaca FERNÁNDEZ TERUELO, Instituciones..., p. 162, que en la práctica y, no siempre, tan sólo se realiza una pormenorizada investigación de la capacidad económica del reo en los casos "de gran trascendencia social" o cuando la acusación particular "toma las riendas del asunto" y solicita todas y cada una de las diligencias que, a su juicio, podrían resultar necesarias para acreditarla.
} 
de su fortuna ${ }^{167}$. Lo cual resultará triplemente negativo. Primero, porque se procederá a imponer una cuota que, en puridad, no se ajustará escrupulosamente a la capacidad económica que posee verdaderamente. Segundo, porque repito, la multa perderá las propiedades preventivo-intimidatorias de las que potencialmente goza con respecto a los más pudientes. Y tercero, porque, en definitiva, todo lo anterior redundará en hacer de la multa una pena más desigual y, consiguientemente, menos justa.

\section{Si aceptamos que la delincuencia socioeconómica tiene un componente ocupacional} y/o profesional cuya intensidad se condiciona al color del cuello (de más a menos, blanco, gris o azul), puede defenderse la idoneidad -sobre el papel- de la inhabilitación para el ejercicio de "profesión, oficio, industria o comercio" (art. $45 \mathrm{CP}$ ) como instrumento con la que combatirla ${ }^{168}$. En efecto, al privar, temporalmente, al reo de la ocupación o profesión de la que se ha servido para cometer el delito con trascendencia económica, se la considera una pena especialmente apta y eficaz tanto en términos de prevención general -intimidatoria- como especial para disuadir y sancionar esta manifestación delictiva ${ }^{169}$.

${ }^{167}$ En este punto, señala FERNÁNDEZ TERUELO, Instituciones..., p. 162, que los instrumentos que, como mucho, se activan a fin de determinar la capacidad económica de quien ha cometido un delito de cuello blanco, se circunscriben a la solicitud de notas simples a los Registros de la Propiedad y Mercantil; el oficio a Hacienda con el objeto de recabar la información tributaria que dicha administración maneja y, en su caso, el auxilio de la Policía Judicial que intentará averiguar con qué recursos cuenta el sujeto activo en cuestión. ${ }^{168}$ No deja de resultar paradójico la poca atención que le ha dispensado el núcleo duro de nuestra doctrina al sistema de penas en general y a esta pena privativa de otros derechos en particular, cuando, además de dar nombre a esta rama del ordenamiento jurídico, la pena constituye el resultado final y natural una vez superadas todas y cada una de las categorías que, a modo de filtro, conforman la Teoría General del Delito. Ciertamente, el estudio de las consecuencias jurídicas suele-salvo honrosas excepciones-quedar en manos de otros operadores jurídicos (jueces, fiscales y abogados) que, lógicamente, muestran mayor preocupación por los aspectos prácticos que por los estrictamente político-criminales o dogmáticos.

${ }^{169}$ Así lo han manifestado, entre otros, BAUCELLS LLADÓS, CPC (106) 2012, pp. 178-179; DE VICENTE MARTÍNEZ, "Sanciones...", pp. 207-210; DE VICENTE REMESAL, "La pena de inhabilitación profesional: consideraciones desde el punto de vista de los fines de la pena", CPC (113) 2014, pp. 64-65; FERNÁNDEZ TERUELO, Instituciones..., p. 170, quien también ha puesto de relieve-si bien con significativos matices- las "grandes posibilidades" de la inhabilitación profesional en la medida en que imposibilita al sujeto el desarrollo de la profesión o actividad "en cuyo ejercicio ha delinquido"; LANDROVE DÍAZ, JpD (31) 1998, pp. 39-40; NIETO MARTÍN, La responsabilidad penal..., p. 299, quien se hace eco de la "buena prensa" de la que goza esta pena en el "derecho penal económico individual" en comparación con la multa; PAREDES CASTAÑÓN, "La responsabilidad penal por productos defectuosos...”, pp. 430-431, quien ha defendido su mayor eficacia preventiva frente a la multa porque "producen en el individuo delincuente un efecto aflictivo no transmisible a terceros". Una sanción que también ha recibido el aval del GEPC que la calificó de especialmente adecuada y recomendó la introducción de la inhabilitación como pena principal en la criminalidad económica, Una propuesta..., p. 34. Una tesis por otra parte ya defendida a principios de los 80 por el gran especialista en la materia TIEDEMANN, CPC (19) 1983, p. 180, quien concluyó "no parece discutible la efectividad del cierre de la empresa y la inhabilitación profesional, que -aplicada con suficiente vigilancia y cuidado respecto de las maneras de eludir sus efectos-son especialmente adecuadas para alejar de la vida económica a los delincuentes profesionales (en sentido estricto)". 
Parece lógico sostener que, tratándose de un delincuente que actúa movido por la consecución de una ventaja o rédito económicos, se sienta amenazado ante la posibilidad cierta de perder su fuente de ingresos. De la misma forma que su, digamos expulsión, siquiera por el tiempo de condena del ámbito de actividad profesional en que operaba, contrarrestará el riesgo de reiteración delictiva, garantizando así la indemnidad futura del bien jurídico-penal previamente lesionado.

6. Ahora bien, en un paralelismo - parcial- con la multa, esta pena también habría visto mermada su eficacia preventivo general y especial. No tanto como consecuencia de su configuración legal, sino, en especial, por una falta de celo en su ejecución judicial. Ciertamente, en la actualidad el legislador ha dejado meridianamente claro que el juzgador debe concretar "expresa y motivadamente" las actividades objeto de la inhabilitación (art. $45 \mathrm{CP}$ ) al tiempo que las ha limitado a aquéllas que guarden "relación directa con el delito cometido" (art. 56.1.3 ${ }^{\circ} \mathrm{CP}$ ). Con ello se ha preservado, respectivamente, el mandato de determinación propio del principio de legalidad y la necesaria proporcionalidad entre la gravedad del hecho cometido y la consecuencia jurídica prevista ${ }^{170}$. Pero insisto, el problema no radicaría tanto en la regulación legal

\footnotetext{
${ }^{170}$ Menciones legales ambas que resultan compatibles con una, digamos, generosa aplicación de la inhabilitación profesional en el marco de la delincuencia socioeconómica que vaya más allá de su habitual focalización judicial al específico sector de actividad en que actuaba el reo (construcción, financiero, químico, alimenticio...), extendiéndose así a lo que FERNÁNDEZ TERUELO, Instituciones..., p. 169, ha denominado "el ejercicio de administración o gestión societaria con carácter general" en el que el bien jurídico-penal afectado se erigiría en el criterio interpretativo rector de la decisión. Efectivamente, como ha apuntado -con razón- dicho autor, si bien puede circunscribirse la inhabilitación al concreto sector en que el delincuente en cuestión cometió el delito cuando el interés lesionado tiene una naturaleza mixta o no exclusivamente "económico-patrimonial" (pensemos en la muerte de un trabajador imputable al incumplimiento grave de las normas preventivo-laborales en materia de riesgos laborales). La solución debería ser, necesariamente, diferente cuando el bien jurídico-penal menoscabado posee una naturaleza estrictamente "económico-patrimonial" (estafa, apropiación indebida, insolvencia punible, delito societario...) en cuyo caso esta, digamos, suspensión temporal habría de ampliarse al "ejercicio de toda actividad empresarial" en la medida en que dichos ilícitos penales constituyen el resultado de un abuso o uso desviado de las facultades consustanciales al cargo de administrador. Si bien dicha tesis podría ser tachada de indeterminada y desproporcionada, a mi juicio, sendas objeciones pueden ser rebatidas. Primero porque no goza de un grado indeterminación menor al caso en que se impone en razón del sector de actividad (sirva como ejemplo la acordada al reo de un delito ecológico al que se le inhabilitó "para el ejercicio de actividades industriales que requieran el manejo de sustancias o productos tóxicos", STS 1592/00, 9-10, RJ. 1562/2000; Pte. Abad Fernández). Y segundo porque su extensión al ejercicio de toda actividad vinculada a la gestión y administración de una empresa, no le impide desarrollar otras ocupaciones o empleos que requieran de una menor cualificación. Así, por ejemplo, el administrador de una sociedad que normalmente estará graduado en económicas o empresariales, podrá trabajar como administrativo o recepcionista porque ello no pondrá en peligro los intereses económicos de la sociedad ni los de aquellos que interactúan con la misma (consumidores, inversores, acreedores).
} 
sino, particularmente, en la clásica y recurrente desatención a la ejecución penal como fase-crucial-del procedimiento, donde la contumaz e insuficiente dotación de medios materiales y humanos destinados a la oficina judicial, habría alimentado la proliferación de ciertas prácticas en la aplicación de una pena, morfológicamente, diseñada para el delincuente de cuello blanco ${ }^{171}$.

\section{Por otra parte, se dice que su imposición como pena principal o como accesoria ga-} rantizaría su extensión a todos los ilícitos incluidos en el Derecho penal de empresa ${ }^{172}$. Siendo esto cierto, también lo es la ausencia de un patrón político-criminal racional a la hora de prever su establecimiento como pena principal, así como la "puerta legal abierta" a su inaplicación de imponerse como accesoria. Como muestra de lo primero,

${ }^{171} \mathrm{Si}$ bien puede calificarse de aceptable la aplicación judicial de esta inhabilitación en el marco de ciertas profesiones colegiadas (médicos, psicólogos, abogados, ingenieros, arquitectos...) u oficios cuya supervisión es ejercida por la Administración (maestros, técnicos electricistas, instaladores de gas, maquinistas de tren...), no puede decirse lo mismo respecto de aquellos otros que carecen de colegio profesional (pensemos, por ejemplo, en el ejercicio en general del cargo como administrador de una sociedad) o del control administrativo directo (por ejemplo, el famoso encargado de obra que opera en la construcción y carece de estatuto jurídico). Efectivamente, mientras en el primer grupo de casos, el Juez o Tribunal podrá garantizar la ejecución de la inhabilitación impuesta por medio del correspondiente oficio al Colegio profesional de turno o a la Administración competente (Ministerio de Educación, de Industria, de Transportes o Consejería análoga en el ámbito autonómico). En los segundos, la efectividad de la misma requerirá una dosis adicional de tiempo, medios y creatividad intelectual, no siempre compatible con la carga, recursos y perfil de nuestros juzgadores. Esta digamos limitación técnico-práctica motivó la clásica discusión doctrinal en torno a la oportunidad de restringir la inhabilitación profesional a aquéllas cuyo ejercicio exigiera de una habilitación, permiso o licencia oficial. Una tesis que ha sido abandonada por la mayoría, pero que, como ha puesto de relieve De Vicente Remesal, CPC (113) 2014, pp. 88-89, todavía defiende un penalista tan significado como MIR PUIG (Derecho penal..., p. 720), seguramente porque "de lo contrario, la efectividad de la sanción sería muy dificil". Estando de acuerdo en que la inexistencia de una habilitación previa condiciona la operatividad de esta pena, entiendo - en la línea apuntada por el primero de los autores citados- que ante ello los Jueces deberían redoblar sus esfuerzos en el efectivo control y supervisión de su ejecución. Una tarea que tienen constitucionalmente encomendada (art. 117.3 CE) y que -en parte- vendrá condicionada por la consabida dotación de medios técnicos y personales que a tal fin proporcione la Administración de Justicia.

${ }^{172}$ Como principal está prevista, conjuntamente con la prisión o bien con la multa y la prisión en los siguientes supuestos: los delitos contra la propiedad intelectual e industrial (arts. 271 y 276); el delito de difusión de noticias falsas sobre empresas (art. 284); los delitos de receptación y afines (arts. 298.2, 302.2 y 303); urbanismo, patrimonio histórico y medio ambiente (arts. 319, 321 y 325-326); los delitos contra la seguridad colectiva (arts. 348-350) y contra la salud pública (arts. 359, 362-364 y 367). En tanto que como pena accesoria, nuestros Jueces y Tribunales pueden extenderla al resto de delitos socioeconómicos (estafa, apropiación indebida, insolvencia punible, delitos societarios...) que tengan prevista una pena de prisión hasta 10 años (art. 56), siempre y cuando, la "profesión, oficio, industria, comercio" esté directamente vinculada con el delito perpetrado y se dé cuenta de la misma expresamente en la Sentencia. Así lo han señalado, recientemente, entre otros, FERNÁNDEZ TERUELO, Instituciones..., p. 166 y BAUCELLS LLADÓS, CPC (106) 2012, pp. 179-180. Dichas penas, en algún caso con el respectivo cambio en la numeración, se mantienen en la reforma operada en la LO 1/2015. 
podría citarse, entre otros, la llamativa omisión de esta pena en el castigo de los delitos societarios (arts. 290-295). O el reciente olvido en que habría incurrido el legislador que tampoco ha tenido a bien incluirla en el delito de administración desleal del patrimonio ajeno (art. 252 vigente a partir del 1 de julio), cuando todos estos ilícitos se caracterizarían, precisamente, por la infracción y/o abuso de los deberes propios de un buen y leal administrador ${ }^{173}$. Pero como decía, en la praxis, su preceptiva imposición como accesoria debe relativizarse, dado que nuestros Jueces y Tribunales sólo están obligados a castigar al delincuente con "alguna o algunas" de las listadas en el art. $56 \mathrm{CP}^{174}$.

8. Es más, aun existiendo mecanismos extra-penales suficientes para garantizar una adecuada y eficaz ejecución de la inhabilitación impuesta a quien, ocupando funciones en la administración o gestión de una sociedad, ha lesionado los intereses económicopatrimoniales de los consumidores, inversores o proveedores que con ella se relacionan ${ }^{175}$. Lo cierto es que dicha pena topa con un obstáculo difícilmente superable cuando, además, dicho administrador -ya inhabilitado penalmente- ostenta la titularidad de la unidad productiva o posee un paquete de acciones o participaciones suficiente para controlarla por medio de terceras personas físicas o un entramado de personas jurídi-

\footnotetext{
${ }^{173}$ En esta línea, destaca BAUCELLS LLADÓS, CPC (106) 2012, págs 181, como de los 40 delitos examinados en su trabajo, sólo 14 tienen prevista la inhabilitación especial como pena principal, circunstancia ésta que limitaría notablemente su campo de aplicación.

${ }^{174}$ No le falta razón en este punto a BAUCELLS LLADÓS, CPC (106) 2012, págs 181, cuando denuncia que ello podría motivar el que nuestros juzgadores no valoren su operatividad en el caso concreto y, contrariamente, se decanten por un formal cumplimiento de este mandato legal a través -añadiría yo- de la autómata imposición de la inhabilitación especial para el derecho de sufragio pasivo (art. 56.1.2 $2^{\mathrm{a}}$. Lo cual, en última instancia, relativizaría el alcance de la inhabilitación profesional decretada como pena accesoria.

${ }^{175}$ Como ha puesto de manifiesto FERNÁNDEZ TERUELO, Instituciones..., p. 170, existen diversos preceptos administrativos y mercantiles que impiden el hecho de que un gestor condenado pueda seguir al frente de una sociedad. Tal es el caso, del art. 213 del RDL 1/2010, Ley de Sociedades de Capital en que se prohíbe la asunción del cargo de administrador, entre otros, a "los condenados por delitos contra la libertad, contra el patrimonio o contra el orden socioeconómico...". O de especial incidencia en el sector de la intermediación financiera, lo previsto en el art. 2 del RD 256/2013, por el que se incorporan a la normativa de las entidades de crédito y de otras entidades financieras los criterios de la Autoridad Bancaria Europea de 22 de noviembre de 2012, sobre la evaluación de la adecuación de los miembros del órgano de administración y de los titulares de funciones clave, en que, entre otros, criterios se atenderá a la "existencia de condenas por la comisión de delitos o faltas y sanciones administrativas" para valorar la "honorabilidad comercial y personal" de quienes formen parte de su Consejo de Administración. En el primer caso, bastaría con que el Juez o Tribunal oficiara al Registro Mercantil el testimonio de la Sentencia en que se decreta la inhabilitación del correspondiente administrador. Y en el segundo, realizar idéntica gestión, pero en esta ocasión dirigida al Banco de España en tanto institución competente en la supervisión de tales requisitos de honorabilidad.
} 
cas interpuestas ${ }^{176}$. El primero denominado coloquialmente "testaferro" u "hombre de paja" permite, al igual que en los supuestos más sofisticados de ingeniería societariofinanciera, una administración de hecho -y en diferido- de aquélla compañía de la que, formal y temporalmente, ha sido apartado como consecuencia de la inhabilitación profesional decretada ${ }^{177}$.

9. Sin embargo, esta suerte de farmacopea punitiva aquí epidérmicamente examinada, quedaría incompleta sin una última $\mathrm{y}$, necesariamente breve, referencia al binomio prisión-delincuencia socioeconómica. Iniciaré este sucinto análisis formulando una pregunta ¿Es la prisión la pena más eficaz para combatir esta manifestación criminal? Desde un punto de vista preventivo-negativo, nadie cuestiona el mayor poder intimidatorio de la prisión en comparación con la multa o la inhabilitación ${ }^{178}$. Pero dando un paso más, diría incluso que su efecto es mayor en el delincuente económico que en el marginal. La razón una y simple. El primero, a diferencia del segundo, tiene mucho más que perder porque, su elevada capacidad económica y mejor posición social, le garantiza un plus de autodeterminación en el plano patrimonial y personal, y, consiguientemente, la pérdida de su libertad tiene un mayor coste de oportunidad. Además, siendo idéntico el resultado

\footnotetext{
${ }^{176}$ A juicio de BAUCELLS LLADÓS, CPC (106) 2012, p. 180, el principal problema que lastra su eficacia viene determinado por el hecho de que "el titular de una empresa inhabilitado por delito económico no perderá su titularidad, ni los beneficios que se derivan de ella". Lo cual, junto a la evitación del "efecto admonitorio de la pena" mediante la designación de testaferros, neutralizaría las "ventajas preventivas intuidas por la doctrina" en relación a esta pena.

177 Un diagnóstico compartido por FERNÁNDEZ TERUELO, Instituciones..., p. 173, quien propone la creación de un modelo autónomo de "(...) inhabilitación para ejercer cargos directivos en empresas" a imagen y semejanza del previsto en el art. 32 bis del CP italiano en el que, junto a la inhabilitación profesional (interdizione da una professione o da un'arte -art. 30), cuentan con una “ (...) inhabilitación temporal de los cargos directivos de las empresas como pena accesoria a las de prisión superiores a seis meses, cuando se trate de delitos cometidos, con abuso de poderes o violación de los deberes inherentes al puesto de administrador". Una medida con la que se podría contrarrestar los supuestos en que los sujetos ya inhabilitados "continúan sin embargo en la sombra desarrollando actividades de gestión societaria", y que, en su opinión, debería complementarse con la expresa mención al administrador de hecho como ya reza en la cláusula del "actuar en lugar de otro" y en algunos delitos societarios.

${ }^{178}$ De hecho, diversos autores avalaron en los 80 y en los 90 la idoneidad de la prisión como respuesta preventivo-sancionadora de la delincuencia socioeconómica. En este sentido, se pronunciaron en nuestra doctrina, entre otros, BAJO FERNÁNDEZ, CPC (5) 1978, p. 28, quien concluyó "sin negar la eficacia de las otras sanciones, a mi juicio, es la pena privativa de libertad la más adecuada para el castigo de los delitos económicos como respuesta a las exigencias de proporcionalidad (con la gravedad del hecho y la culpabilidad) y a la necesidad de una prevención general"; MARTÍNEZ-BUJÁN PÉREZ, "Consecuencias jurídicas económicas en el sector de la delincuencia económica”, DPyCr (57-58) 1995-1996, p. 13, quien señaló "rigurosos estudios empíricos han demostrado la incuestionable eficacia de las penas privativas de libertad para la represión de la delincuencia económica a la vista del potencial círculo de autores (personas de alto nivel económico y socialmente adaptadas)".
} 
de su imposición (la privación de la libertad), a mi juicio, será superior en el caso del delincuente de cuello blanco dado el coste adicional de orden reputacional -social y profesional- que para él comportará un efectivo ingreso en prisión ${ }^{179}$.

10. Ahora bien, el hecho de que potencialmente la prisión sea la más intimidatoria de las penas, en modo alguno, justifica que los comportamientos protagonizados por estos delincuentes deban, necesariamente, ser reprimidos con elevadísimas privaciones de libertad $^{180}$. Dos argumentos avalarían esta aseveración. En primer lugar, la constatación empírica de que el efecto preventivo de toda pena -también la prisión- no depende tanto de su gravedad en términos cuantitativos, sino especialmente, de las mayores o menores probabilidades de imposición percibidas por el potencial autor ${ }^{181}$. Como han

${ }^{179}$ En parecidos términos se ha pronunciado, entre otros, FERNÁNDEZ TERUELO, Instituciones..., p. 149, quien menciona el mayor "impacto emocional" y "estigma social" que la prisión tiene para el delincuente económico en la medida en que, respectivamente, le significará la “(...) integración en un ambiente marginal (...) cuyos estándares de vida están muy alejados de ese modelo" y le supondrá un coste mayor “(...) en su entorno - social” y en el ámbito de una actividad como la económica muy sensible a este tipo de acontecimientos. Como ha señalado -con acierto-ORTIZ DE URBINA GIMENO, "Análisis económico del derecho y política criminal", RDPC (n 2 extraordinario) 2004, p. 58, nota. 59, a veces los llamados "efectos reputacionales" de las sanciones “(...) pueden tener mayor entidad que los legales" y su cuantificación es especialmente relevante en el examen de los costes generales que el delito supone para el delincuente.

${ }^{180}$ Como señala ORTIZ DE URBINA GIMENO, "El derecho penal económico...", p. 140, la mala puntuación, en términos de disuasión de la sanción, obtenida por la delincuencia de cuello blanco en las variables relativas a la "probabilidad" y la "rapidez" puede conducir al legislador-como así sucede desgraciadamente- a operar sobre la tercera -la dureza de la pena-como forma de compensación. De ahí que más adelante concluya "las estrategias disuasorias actualmente seguidas contra este tipo de delincuencia no tienen visos de resultar efectivas, por lo que deben ser sustituidas por otras en las que, sin diluir el efecto preventivo mediante la previsión de penas muy bajas, se incremente la probabilidad de detección y la rapidez en la tramitación del proceso" (pp. 141-142).

${ }^{181}$ Así lo han puesto de relieve en nuestra doctrina, entre otros, BAUCELLS LLADÓS, CPC (106) 2012, p. 170, quien señala "el delincuente normalmente no se motiva por la amenaza de esta pena, -en referencia a la prisión-sino por la idea de cuáles son las posibilidades de que efectivamente se le imponga a él la pena. Y los dos aspectos son muy relevantes en la delincuencia económica..."; CORCOY BIDASOLO, RDF (8) 2012, p. 47, quien concluye "Se olvida que el efecto disuasorio de las penas se fundamenta, esencialmente, en la certeza en su cumplimiento. Y ello no puede verse como algo contrario a las garantías, sino como la necesaria eficacia del sistema judicial que a su vez posibilita la aplicación de las penas sin merma de las garantías"; ORTIZ DE URBINA GIMENO, "El derecho penal económico...”, p. 140, quien advierte "los estudios empíricos muestran que la gravedad de la sanción, en ausencia de una probabilidad suficiente de imposición, tiene escasos efectos preventivos, de modo que esta vía de actuación, en términos estrictamente disuasorios, no resulta indicada"; y en la doctrina norteamericana, entre otros, ROBINSON, P. H., "Control coercitivo del delito vs. Control normativo del delito. ¿Por qué le importa al derecho penal lo que los legos consideran justo?, (Gómez-Jara Díez, Trad.), en Derecho penal del enemigo. El discurso penal de la exclusión, CANCIO MELIÁ / GÓMEZ-JARA DÍEZ (coords.), Vol. 2, Eds. Edisofer/Bdef, MadridMontevideo, 2006, p. 817, quien concluye "El efecto de una amenaza disuasoria es el resultado de la severidad del castigo con el que se amenaza, y la probabilidad de que dicho castigo termine imponiéndose tras la infracción. Con otras palabras; la probabilidad de la detección es una variable importante dentro de la fórmula de la disuasión". 
enfatizado los partidarios del análisis económico del derecho (AED), "el valor esperado de una sanción se obtiene en principio multiplicando su magnitud por la probabilidad de su imposición" "182. Ello significa que una pena corta de prisión que efectivamente se cumplirá disuade más que una de mayor duración cuya probabilidad de cumplimiento es incierta ${ }^{183}$. Y en segundo lugar, así lo exige la ineludible observancia del principio de proporcionalidad tanto en la configuración de la norma penal objeto de la prohibición como en la determinación de la cantidad de pena prevista como respuesta ${ }^{184}$. Ciertamente, la pena será legítima cuando, además de proteger un bien jurídico merecedor de la misma, no existan otros recursos menos limitadores de derechos -fundamentales- que garanticen su idéntica o semejante tutela ${ }^{185}$.

182 Vid., ORTIZ DE URBINA GIMENO, RDPC (nº 2 extraordinario) 2004, sin lugar a dudas uno de los mayores valedores de esta corriente de pensamiento en nuestra doctrina cuya aplicación al ámbito del análisis económico del crimen en general y a la política criminal en particular ha defendido con matices.

${ }^{183}$ Según los partidarios de este planteamiento para incrementar el coste del delito y lograr así la disminución de éste último se puede optar por el aumento de la probabilidad de condena o bien la agravación de la pena. Resulta evidente que nuestro legislador se ha decantado claramente por la segunda opción que, a todas luces, resulta menos costosa económicamente y más rentable electoralmente. Mientras que la mejora de la primera variable pasa por la inyección de numerosos recursos en el Sistema de Justicia Penal (dícese, más efectivos policiales, más fiscales y jueces y el refuerzo de los medios destinados a la Administración Penitenciaria), la primera sólo requiere contar con la mayoría parlamentaria necesaria y activar la palanca del endurecimiento penal. En esta línea se han expresado, entre otros, muy gráficamente, CORCOY BIDASOLO, RDF (8) 2012, p. 46, cuando señala "Se ha impuesto la creencia, generalizada en la clase política, de que el endurecimiento de los delitos propicia un mayor número de votos", una creencia -continúa la autora- alimentada por el amarillismo sensacionalista practicado por una gran parte de los medios de comunicación (p. 49); y ORTIZ DE URBINA GIMENO, RDPC (nº 2 extraordinario) 2004, pp. 58-59, quien concluye "Menores son los costes que suelen asociarse al aumento del valor esperado de la sanción por medio del incremento de la dureza. Al fin y al cabo, da la impresión que lo único que hay que hacer en este caso es lograr reunir a un número suficiente de parlamentarios un día dado y que estos voten a favor del mencionado incremento".

${ }^{184}$ Como han puesto de relieve, entre otros, CORCOY BIDASOLO, RDF (8) 2012, p. 48, la eficacia no puede erigirse en el único criterio a tomar en consideración porque, de ser así, nos veríamos abocados a un "estado policial". De ahí que -continúa la autora- toda decisión legislativa encaminada a ampliar delitos o endurecer la pena de los ya existentes, deba ir precedida de un pausado y racional análisis acerca de la lesividad que el nuevo comportamiento implica para terceros y la posibilidad real de prevenirlo y, en su caso sancionarlo, acudiendo a otras medidas menos restrictivas de derechos cuando el mal causado con la intervención penal es mayor al que se pretende evitar. Un peligro del que también nos advierte ORTIZ DE URBINA GIMENO, RDPC ( $\mathrm{n}^{\circ} 2$ extraordinario) 2004, p. 59, cuando califica de draconiana la sanción ideal ("aquella cuya gravedad tiende al infinito y cuya probabilidad de imposición tiende a cero") a las que nos conduciría un análisis económico del delito desprovisto de aquellos aspectos que le restarían la "fiereza político-criminal" denunciada por sus muchos detractores: "la forma óptima de sanción", la "disuasión marginal" y el "descuento de futuro" (pp. 60-63).

${ }^{185}$ Así lo ha expresado mejor que yo, entre otros, LASCURAÍN SÁNCHEZ, "Cuándo penar, cuánto penar", en El principio de proporcionalidad penal, LASCURAÍN SÁNCHEZ / RUSCONI (dirs.), Ed. Ad-hoc, Buenos Aires, 2014, p. 326, cuando concluye "Una norma penal resulta proporcionada si no puede ser eficazmente sustituida por una intervención menos contundente, y si, además, bien mirado lo que salva y 
11. Por otra parte, el hecho de que el delincuente económico goce de un mayor grado de formación y socialización no constituye un obstáculo para cuestionar per se la opción de la prisión. De hecho, es más que probable que las habilidades sociales con las que cuenta le permitan superar con garantías el "efecto estigmatizador" consustancial a la misma $^{186}$. En efecto, aun partiendo de una concepción estricta de prevención especial -por otra parte absolutamente en crisis- que asigna, en exclusiva, a la cárcel el papel de reinsertar y/o reeducar al penado, puede no compartirse la idea según la cual el autor de delitos económicos no requiere de tratamiento alguno y, consiguientemente, carece de sentido la imposición de penas privativas de libertad. El hecho de que en el ámbito penitenciario todavía no se haya implementado un programa ad hoc para esta concreta tipología delictiva -como sí sucede en el ámbito de los delitos sexuales, la violencia de género o, más recientemente, la delincuencia vial- nada obsta a su recomendable diseño y ejecución futura. Con ello quizás podamos lograr un doble objetivo. En primer lugar, dotar al delincuente económico de útiles herramientas que le permitan contrarrestar las distintas técnicas de neutralización de las que, en ocasiones, se sirve para justificar su comportamiento delictivo, $\mathrm{y}$, acto seguido, minusvalorar las graves consecuencias individuales -y sociales- que tal acción conlleva. Y en segundo lugar, evitar su repetición una vez superada la -hipotética- estancia carcelaria mediante la saludable internalización de la negativa experiencia vivida en un régimen de privación de libertad ${ }^{187}$. Desde luego, se trata de una finalidad preventivo especial más modesta, pero quizás también más acorde con la realidad de nuestra Administración Penitenciaria.

12. A mi juicio, sendos objetivos sólo requerirían la imposición de penas de prisión de corta duración, justo, al revés, de lo que sucedería con el delincuente marginal cuyas recurrentes y fugaces entradas en la cárcel pueden agravar tanto su precario arraigo

\footnotetext{
lo que sacrifica, no resulta una norma más coactiva que liberadora. Presupuestos de este balance positivo son los de que la norma pretenda proteja un bien legítimo y pueda además hacerlo".

${ }^{186}$ Vid., BAUCELLS LLADÓS, CPC (106) 2012, p.146. Basta traer a colación en este sentido dos ejemplos recientes de nuestra realidad penitenciaria (Luis Bárcenas y Díaz Ferrán) para comprobar como las altas capacidades socio-formativas no sólo les facilitaron una -aparente- rápida adaptación a su nueva vida en prisión, sino, en especial, una notable sintonización y empatía con los otros reclusos con los que compartían su día a día.

${ }^{187}$ En esta línea, se han expresado, recientemente, BAUCELLS LLADÓS, CPC (106) 2012, p. 165, quien apela a la prevención especial como forma de "conseguir que el delincuente no vuelva a delinquir para evitar el efecto negativo vivido en la experiencia de privación de libertad" y FERNÁNDEZ TERUELO, Instituciones..., p. 153, quien concluye "también el delincuente económico es un sujeto desocializado, si bien lo es en un sentido distinto al que se ha manejado tradicionalmente. Aunque el mismo no es un marginado y no carece por ello de arraigo social (...) si está carente de un grado de socialización, en la medida que realiza conductas consideradas antisociales, que denotan una falta de aceptación y de respeto respecto a bienes jurídicos relevantes".
} 
social como sus - posibles- toxicomanías. Comparto el sentir mayoritario contrario, en general, a la utilización de las penas privativas de libertad inferiores a seis meses no sólo porque contribuyen a debilitar la socialización del penado habituado al sistema carcelario, sino también porque le posibilita el perfeccionamiento de los conocimientos técnico-prácticos que pudiera atesorar en su, digamos, campo de especialización criminal (p.e., los hurtos, robos con fuerza, salud pública...). Sin embargo, quizás una pena corta de prisión con alta probabilidad de ejecución sea el antídoto perfecto para prevenir y, en su caso, castigar muchas de las conductas contenidas en el Derecho penal de empresa ${ }^{188}$.

13. Eso sí, siempre y cuando, se cumplan previamente dos presupuestos fundamentales. Primero, sólo deberían elevarse a la categoría de delito aquellos comportamientos que, material y efectivamente, posean un grado de dañosidad suficiente para justificar la imposición de una consecuencia jurídica tan gravosa. Ello obligaría al legislador a resetear todos los tipos contenidos en el Derecho penal de empresa y a resintonizar la siempre tormentosa delimitación con los correspondientes ilícitos civiles/mercantiles/ administrativos y laborales ya existentes. Una tarea cuyo éxito requerirá, a su vez, de un adecuado período de reflexión y un sosegado estudio en pro de la mejor solución político-criminal ${ }^{189}$. Y segundo, y con el fin de evitar la desnaturalización de la prisión legalmente prevista, sería especialmente aconsejable extremar los requisitos exigidos en la concesión de la suspensión y/o sustitución de las penas privativas de libertad en una triple dirección: a) condicionando ambos sustitutivos penales a la efectiva, puntual y completa satisfacción de las responsabilidades civiles ex delicto, así como a la íntegra y acreditada devolución del producto obtenido a resultas del delito cometido (dinero, vehículos, inmuebles, joyas, acciones...); b) imponiendo adicionalmente alguna de las obligaciones contenidas en el art. 83 del CP (p.e., la realización de un curso de sensibilización medioambiental de haber sido condenado a un delito ecológico); y

\footnotetext{
${ }^{188}$ Una tesis en su día compartida por reputados especialistas en la materia como BAJO FERNÁNDEZ, CPC (5) 1978, pp. 28-29, quien, siguiendo en este punto al maestro alemán TIEDEMANN, concluyó "las penas cortas privativas de libertad son aqui de especial interés porque las dificultades que se le atribuyen para la función de resocialización carecen aqui de sentido, ya que el delincuente de las capas altas y medias de la sociedad no está normalmente necesitado de ello. Además, el cumplimiento de penas cortas produce un efecto intimamente a nivel individual y social que no puede relegarse al olvido, y por último, el sistema de los días-multa no ha demostrado aún su eficacia. Por último, si hay algún delito en el que no está indicada la aplicación de la condena condicional es precisamente en los delitos económicos". En contra de la imposición de penas cortas de prisión y de la limitación de los sustitutivos penales en los supuestos de delincuentes socioeconómicos, se ha pronunciado BAUCELLS LLADÓS, CPC (106) 2012, pp. 171-174. ${ }^{189}$ Una búsqueda en la que no estaría de más contar con la asistencia técnica de los más significados especialistas en cada una de las materias objeto de análisis.
} 
c) relegando la utilización de la multa como pena sustitutiva y situando en su lugar y de forma exclusiva los trabajos en beneficio de la comunidad sin supeditación a la prestación del consentimiento del reo $^{190}$. La puesta en marcha de todas estas medidas ayudarían a combatir la sensación ciudadana de que el -socializado-delincuente económico obtiene más fácilmente un sustitutivo penal o accede con mayor celeridad a los beneficios penitenciarios que le aseguran una situación de (semi)libertad (permisos, tercer grado, libertad condicional....) y, consecuentemente, un acortamiento de su permanencia efectiva en prisión ${ }^{191}$.

14. No quisiera concluir el presente trabajo sin realizar un apunte victimológico a fin de calibrar el papel de la propia víctima no sólo en su condición de sujeto pasivo del delito, sino también como agente "colaborador" en su comisión. En efecto, se ha constatado empíricamente que la víctima con su actuar - poco o nada diligente- contribuiría igualmente a conformar los márgenes de riesgo - penal-y, por ende, ocuparía, según el ámbito de actividad, un lugar determinante en su proceso de victimización. Tomando como premisa el triángulo de la oportunidad delictiva, bueno sería que los poderes públicos, además de desincentivar las motivaciones del delincuente económico, reforzaran los mecanismos de autoprotección de las potenciales víctimas como forma de prevención de tales hechos delictivos. En este punto y como se ha insistido a lo largo de esta investigación, devendrá esencial la información previa de que dispone la víctima cuando, generalmente, opera en el tráfico jurídico-mercantil y, en particular,

\footnotetext{
${ }^{190}$ Así, por ejemplo, la sustitución de la prisión por la asistencia del empresario condenado por la muerte de un operario imputable a la grave omisión de medidas de seguridad en el trabajo a un centro de rehabilitación de lesionados medulares. Mediante la imposición de esta pena alternativa el empresario tomaría conciencia de los elevadísimos costes humanos -y económicos- que comporta el incumplimiento de sus obligaciones preventivo-laborales, al tiempo que podría retornar a la sociedad el daño que su reprochable comportamiento ha traído consigo en forma de servicio comunitario.

${ }^{191}$ Especialmente crítico con esta idea se ha mostrado RUIZ RODRÍGUEZ, RDPC (1) 2009, pp. 390-394, quien ha cuestionado esta suerte de derecho penitenciario de dos velocidades cuando se trata de su aplicación a los reclusos -marginales- de siempre o, por contra, a los -socializados-delincuentes ocasionales de cuello blanco. Como ha apuntado muy atinadamente FERNÁNDEZ TERUELO, Instituciones..., pp. 151-152, tres factores incidiarían en la elusión por el delincuente económico de la prisión hipotéticamente impuesta: a) en primer lugar, los propios marcos penales fijados por el legislador cuya amplitud favorece la imposición de penas de prisión de hasta 2 años; b) en segundo lugar, la menor tasa de reincidencia registrada en esta tipología delictiva, donde en los -más bien modestos-supuestos en que el delincuente económico es condenado, es expulsado del ámbito de actividad económica en que operaba, cerrando así las puertas a la repetición del hecho delictivo cometido; y c) en tercer lugar, el elemento que califica -con razón-como clave, esto es, el hecho de que las circunstancias a tomar en consideración para calibrar el pronóstico de peligrosidad criminal (el conocido como arraigo social) resulten especialmente favorables al delincuente de cuello blanco al tratarse, a diferencia del marginal, "precisamente (...) de un sujeto con medios y condiciones para ello, valoración que, por todo lo expuesto, puede extenderse al pronóstico de peligrosidad futura".
} 
se interesa o le ofrecen un producto financiero de especial complejidad ${ }^{192}$. De contar con un adecuado y comprensible haz informativo el ciudadano-consumidor podrá calibrar mejor los riesgos económico-financieros que conlleva su participación en dicho ámbito, así como la concreta decisión a tomar en su -puntual-interacción con los intermediarios financieros ${ }^{193}$.

15. En definitiva, las Administraciones Públicas han de desarrollar acciones tendentes a elevar el umbral de conocimientos económico-financieros de la población, así como a advertir de los renovados riesgos que el desarrollo de las nuevas tecnologías suponen no sólo para su intimidad y libertad sexual, sino también la óptima tutela de sus intereses patrimoniales $^{194}$. Los poderes públicos pueden lograr dichos objetivos por la vía -acumulativa- de las campañas de sensibilización social, la incorporación de asignaturas obligatorias en primaria y secundaria. Y, por supuesto, como ya viene haciendo - de forma más intensa a raíz de la crisis-mediante la imposición de obligaciones reforzadas de información a los distintos agentes del mercado financiero, especialmente, cuando el destinatario de estos intrincados productos carece de un perfil profesionalizado. Este conjunto de medidas proporcionará a la víctima las herramientas necesarias para contrarrestar -más eficazmente- los riesgos derivados de las clásicas formas de criminalidad económica (estafa, apropiación indebida....). Pero también aquellos otros -más o menos sofisticados- que, al compás del desarrollo experimentado por las TIC's, se han multiplicado (p.e, fraudes con tarjetas de crédito, invest fraud, ponzi frauds, estafas de la lotería, action fraud o las distintas formas de phishing ${ }^{195}$ ), ampliando así, exponencialmente, el radio de acción de quienes sufrirán sus negativas consecuencias ${ }^{196}$.

${ }^{192}$ Como ha puesto de relieve, entre otros, PÉREZ VALERO, "Delitos societarios...", p. 299, el punto débil de la llamada "filosofía de la transparencia en los Mercados de Valores" trae causa del hecho de que los principales beneficiarios de la información económico-financiera, esto es, los ciudadanos-inversores, son los que tienen más dificultades para entenderla. Lo cual les impediría tomar la mejor decisión a la hora de invertir en productos de tal complejidad.

${ }^{193}$ Así, por ejemplo, ante la oferta de un producto financiero complejo dicha información le permitirá, entre otras opciones: a) rechazarlo; b) solicitar un plus de información a un tercero imparcial (p.e, la oficina de atención al consumidor; una organización no gubernamental protectora de los consumidores; un amigo con conocimientos sobre la materia...) en caso de que albergue alguna duda adicional acerca de los riesgos que su adquisición comporta; o bien c) comprarlo con pleno conocimiento y absoluta libertad, asumiendo, en este caso, las negativas consecuencias patrimoniales consustanciales a una inversión de cuya alta peligrosidad financiera es consciente.

${ }^{194}$ Un presupuesto absolutamente necesario para que la víctima tome cabal conciencia de los peligros que comportan y, seguidamente, aumente las medidas de autoprotección con los que combatirlos.

$195 \mathrm{Vid}$., al respecto ampliamente las distintas formas de cibercriminalidad económica detalladas en la magnífica monografía elaborada por MIRÓ LLINARES, El cibercrimen...., pp. 237-244.

${ }^{196}$ Para un análisis pormenorizado del perfil de la cibervíctima resulta ineludible en nuestra doctrina el trabajo realizado MIRÓ LLINARES, El cibercrimen ...., pp. 261 y ss., en que da cuenta de las especificaciones en atención a la manifestación criminal desplegada en el ciberespacio. 